\title{
Interventions targeted at women to encourage the uptake of cervical screening (Review)
}

\author{
Everett T, Bryant A, Griffin MF, Martin-Hirsch PPL, Forbes CA, Jepson RG
}

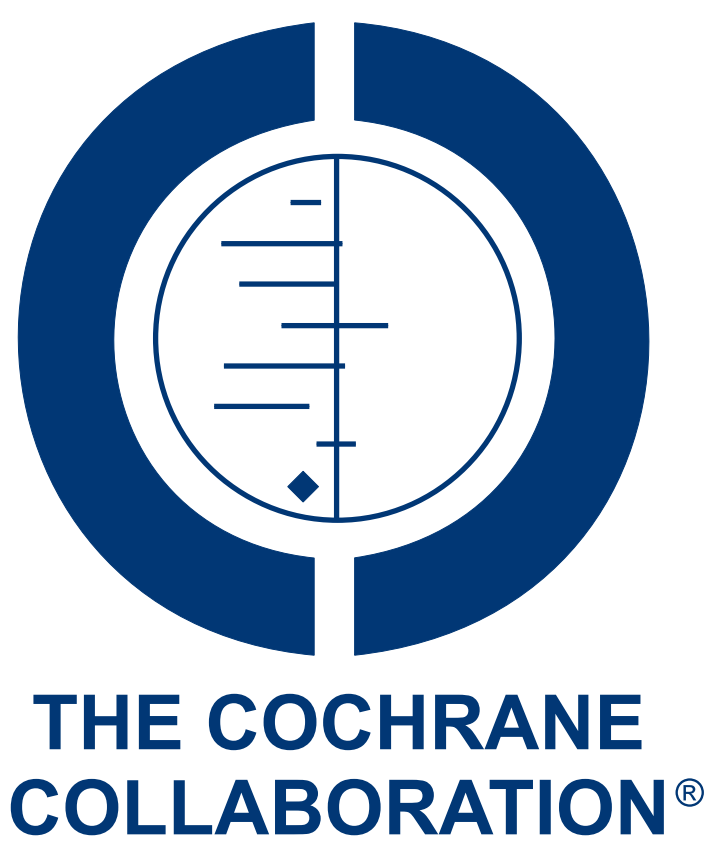

This is a reprint of a Cochrane review, prepared and maintained by The Cochrane Collaboration and published in The Cochrane Library 2011, Issue 5

http://www.thecochranelibrary.com

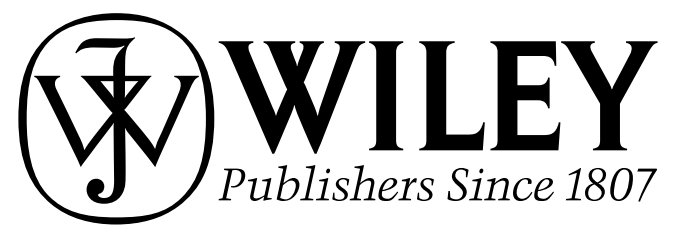

Interventions targeted at women to encourage the uptake of cervical screening (Review)

Copyright (C) 201 I The Cochrane Collaboration. Published by John Wiley \& Sons, Ltd. 
TABLE OF CONTENTS

HEADER . . . . . . . . . . . . . . . . . . . . . . . . . . . . . . . . . . . . . . . 1

ABSTRACT . . . . . . . . . . . . . . . . . . . . . . . . . . . . . . . . . . . . . . . . . . . . . . 1

PLAIN LANGUAGE SUMMARY . . . . . . . . . . . . . . . . . . . . . . . . . . . . . . . . . . . . . . $\quad . \quad 2$

BACKGROUND . . . . . . . . . . . . . . . . . . . . . . . . . . . . . . . . . . . . 2

OBJECTIVES . . . . . . . . . . . . . . . . . . . . . . . . . . . . . . . . . . . . . 44

METHODS . . . . . . . . . . . . . . . . . . . . . . . . . . . . . . . . . . . . . . 44

Figure 1. . . . . . . . . . . . . . . . . . . . . . . . . . . . . . . . . . . . . . 6

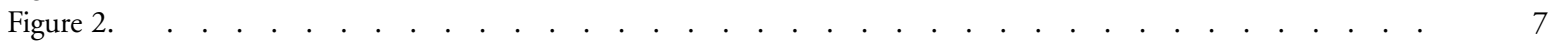

RESULTS . . . . . . . . . . . . . . . . . . . . . . . . . . . . . . . . . . . . . . . 8

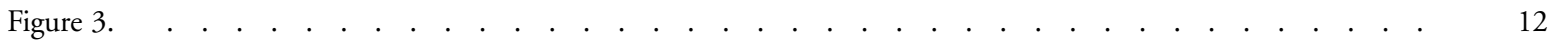

DISCUSSION . . . . . . . . . . . . . . . . . . . . . . . . . . . . . . . . . . . . . 17

AUTHORS' CONCLUSIONS . . . . . . . . . . . . . . . . . . . . . . . . . . . . . . . . . . . . . . . 19

ACKNOWLEDGEMENTS . . . . . . . . . . . . . . . . . . . . . . . . . . . . . . . . . . 19

REFERENCES . . . . . . . . . . . . . . . . . . . . . . . . . . . . . . . . . . . . . 20

CHARACTERISTICS OF STUDIES . . . . . . . . . . . . . . . . . . . . . . . . . . . . . . . . . . . . . . $\quad 27$

DATA AND ANALYSES . . . . . . . . . . . . . . . . . . . . . . . . . . . . . . . . . . . . . . . . . . . . . . 73

Analysis 1.1. Comparison 1 Invitation vs control, Outcome 1 Uptake of screening. . . . . . . . . . . . . . . . . 77

Analysis 2.1. Comparison 2 GP invitation letter vs invitation letter from other authority sources, Outcome 1 Uptake of screening.

Analysis 3.1. Comparison 3 Personal invitation vs invitation letter, Outcome 1 Uptake of screening. . . . . . . . . $\quad 80$

Analysis 4.1. Comparison 4 Letter with fixed appointment vs letter with open invitation to make an appointment, Outcome 1 Uptake of screening. . . . . . . . . . . . . . . . . . . . . . . . . . . . . . . . 81

Analysis 5.1. Comparison 5 Education vs control, Outcome 1 Uptake of screening. . . . . . . . . . . . . . . . 82

Analysis 6.1. Comparison 6 Education vs other, Outcome 1 Uptake of screening. . . . . . . . . . . . . . . . . . . . $\quad 83$

Analysis 6.2. Comparison 6 Education vs other, Outcome 2 Lay health outreach worker and media education vs media education.

Analysis 6.3. Comparison 6 Education vs other, Outcome 3 Standard invitation and printed education vs standard invitation. . . . . . . . . . . . . . . . . . . . . . . . . . . . . . . .

Analysis 7.1. Comparison 7 Counselling vs control, Outcome 1 Uptake of screening. . . . . . . . . . . . . . 85

Analysis 8.1. Comparison 8 Counselling vs other, Outcome 1 Uptake of screening. . . . . . . . . . . . . . . . . . 85

Analysis 9.1. Comparison 9 Enhanced risk assessment vs control, Outcome 1 Uptake of screening. . . . . . . . . . 86

Analysis 10.1. Comparison 10 Enhanced risk assessment vs other, Outcome 1 Uptake of screening. . . . . . . . $\quad$. 86

Analysis 11.1. Comparison 11 Access to health promotion nurse vs control, Outcome 1 Uptake of screening. . . . $\quad 87$

Analysis 12.1. Comparison 12 Photocomic vs placebo comic, Outcome 1 Uptake of screening. . . . . . . . . . . $\quad$. 87

Analysis 13.1. Comparison 13 Intensive recruitment attempts vs control, Outcome 1 Uptake of screening. . . . . $\quad$. 88

Analysis 14.1. Comparison 14 Message framing, Outcome 1 Gain versus loss message framing (Detection). . . . . $\quad 88$

Analysis 14.2. Comparison 14 Message framing, Outcome 2 Gain versus loss message framing (Prevention). $\quad . \quad$. $\quad 89$

Analysis 14.3. Comparison 14 Message framing, Outcome 3 Gain Message Framing: Prevention vs Detection. $\quad . \quad 89$

Analysis 14.4. Comparison 14 Message framing, Outcome 4 Loss Message Framing: Prevention vs Detection. . . . 99

ADDITIONAL TABLES . . . . . . . . . . . . . . . . . . . . . . . . . . . . . . . . . . 90

APPENDICES . . . . . . . . . . . . . . . . . . . . . . . . . . . . . . . . . . . . . . . . 92

WHAT'S NEW . . . . . . . . . . . . . . . . . . . . . . . . . . . . . . . . . . . . . . . . . . . 94

HISTORY . . . . . . . . . . . . . . . . . . . . . . . . . . . . . . . . . . . . . 94

CONTRIBUTIONS OF AUTHORS . . . . . . . . . . . . . . . . . . . . . . . . . . . . . . . . . . . . . . . . . . . 9.95

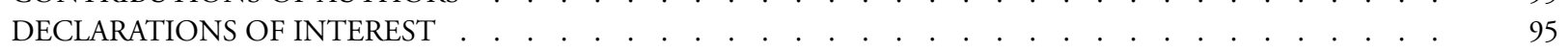

SOURCES OF SUPPORT . . . . . . . . . . . . . . . . . . . . . . . . . . . . . . . . . . . . . . . . . . . . . . 95

DIFFERENCES BETWEEN PROTOCOL AND REVIEW . . . . . . . . . . . . . . . . . . . . . . . . . 95

INDEX TERMS . . . . . . . . . . . . . . . . . . . . . . . . . . . . . . . . . . . . 95

Interventions targeted at women to encourage the uptake of cervical screening (Review)

Copyright $(201$ I The Cochrane Collaboration. Published by John Wiley \& Sons, Ltd. 


\title{
[Intervention Review]
}

\section{Interventions targeted at women to encourage the uptake of cervical screening}

\author{
Thomas Everett ${ }^{1}$, Andrew Bryant ${ }^{2}$, Michelle F Griffin ${ }^{1}$, Pierre PL Martin-Hirsch ${ }^{3}$, Carol A Forbes ${ }^{4}$, Ruth G Jepson ${ }^{5}$ \\ ${ }^{1}$ Department of Gynaecological Oncology, Addenbrooke's Hospital NHS Foundation Trust, Cambridge, UK. ${ }^{2}$ Institute of Health \\ and Society, Newcastle University, Newcastle upon Tyne, UK. ${ }^{3}$ Gynaecological Oncology Unit, Royal Preston Hospital, Lancashire \\ Teaching Hospital NHS Trust, Preston, UK. ${ }^{4}$ NHS Centre for Reviews \& Dissemination, University of York, York, UK. ${ }^{5}$ Department \\ of Nursing and Midwifery, University of Stirling, Stirling, UK \\ Contact address: Thomas Everett, Department of Gynaecological Oncology, Addenbrooke's Hospital NHS Foundation Trust, BOX \\ 242, Addenbrooke’s Hospital, Hills Road, Cambridge, CB2 0QQ, UK. thomaseverett@doctors.org.uk. \\ Editorial group: Cochrane Gynaecological Cancer Group. \\ Publication status and date: New search for studies and content updated (no change to conclusions), published in Issue 5, 2011. \\ Review content assessed as up-to-date: 28 March 2011. \\ Citation: Everett T, Bryant A, Griffin MF, Martin-Hirsch PPL, Forbes CA, Jepson RG. Interventions targeted at women to \\ encourage the uptake of cervical screening. Cochrane Database of Systematic Reviews 2011, Issue 5. Art. No.: CD002834. DOI: \\ 10.1002/14651858.CD002834.pub2.
}

Copyright (C) 2011 The Cochrane Collaboration. Published by John Wiley \& Sons, Ltd.

\begin{abstract}
A B S T R A C T
Background

World-wide, cervical cancer is the second most common cancer in women. Increasing the uptake of screening, alongside increasing informed choice is of great importance in controlling this disease through prevention and early detection.
\end{abstract}

\section{Objectives}

To assess the effectiveness of interventions aimed at women, to increase the uptake, including informed uptake, of cervical cancer screening.

\section{Search methods}

We searched the Cochrane Gynaecological Cancer Group Trials Register, Cochrane Central Register of Controlled Trials (CENTRAL), Issue 1, 2009. MEDLINE, EMBASE and LILACS databases up to March 2009. We also searched registers of clinical trials, abstracts of scientific meetings, reference lists of included studies and contacted experts in the field.

\section{Selection criteria}

Randomised controlled trials (RCTs) of interventions to increase uptake/informed uptake of cervical cancer screening.

Data collection and analysis

Two review authors independently abstracted data and assessed risk of bias. Where possible the data were synthesised in a meta-analysis.

\section{Main results}

Thirty-eight trials met our inclusion criteria. These trials assessed the effectiveness of invitational and educational interventions, counselling, risk factor assessment and procedural interventions. Heterogeneity between trials limited statistical pooling of data. Overall, however, invitations appear to be effective methods of increasing uptake. In addition, there is limited evidence to support the use of educational materials. Secondary outcomes including cost data were incompletely documented so evidence was limited. Most trials were at moderate risk of bias. Informed uptake of cervical screening was not reported in any trials. 


\section{Authors' conclusions}

There is evidence to support the use of invitation letters to increase the uptake of cervical screening. There is limited evidence to support educational interventions but it is unclear what format is most effective. The majority of the studies are from developed countries and so the relevance to developing countries is unclear.

\section{PLAIN LANGUAGE SUMMARY}

\section{Invitations and probably educational interventions increase the uptake of Pap smears}

Cervical cancer is the second most common cancer world-wide. Increasing the uptake of screening is of great importance in controlling this disease through early detection and treatment of pre-cancerous changes before malignancy evolves. Methods of encouraging women to undergo cervical screening include invitations, reminders, education, message framing, counselling, risk factor assessment, procedures and economic interventions. These were all examined in this review. Evidence supports the use of invitations, and to a lesser extent, educational materials. It is likely other methods are advantageous, but the evidence is not as strong. Further research is required.

\section{B A C K G R O U N D}

\section{Description of the condition}

Cervical cancer is the second most common cancer among women (GLOBOCAN 2008). A woman's risk of developing cervical cancer by age 65 years ranges from $0.8 \%$ in developed countries to $1.5 \%$ in developing countries. The management varies around the world dependent on resources and policy however the mainstay of treatment most commonly involves surgery requiring hysterectomy and chemotherapy or radiotherapy. In Europe and the USA, the 5 year survival rate is between $60 \%$ and $72 \%$ (EUROCARE 2003; Jemal 2008) and in England and Wales between 2001 and 2006, the 5 year survival rate was $64 \%$ (ONS 2010).

\section{Primary and secondary prevention}

Human papillomavirus (HPV) infection is believed to be an important primary cause of cancer of the cervix, with a recent study estimating the world-wide HPV prevalence in cervical cancers to be $99.7 \%$ (Walboomers 1999). In particular, two subtypes of the virus HPV (16 and 18) are present in over $80 \%$ of invasive cervical cancers. Other known risk factors for cervical cancer include smoking (Brinton 1986), the early onset of sexual activity, multiple sexual partners, the presence of other sexually transmitted diseases (STDs) (La Vecchia 1986) and the immunological status of the woman (Schneider 1983). Individuals who receive immunosuppressive therapy for organ transplants and those infected with human immunodeficiency virus (HIV) are therefore particularly at risk of developing pre-invasive disease. Primary strategies to prevent the development of cervical cancer focus on reducing these known risk factors by encouraging a healthy lifestyle, smoking cessation and the adoption of 'safer' sexual behaviours aimed at reducing the risk of HPV infection (Shepherd 2011).

The understanding the role of HPV in cervical cancer has led to the development of the HPV vaccination. An immunisation programme has now been rolled out across many countries. Initial results are promising, though longer term population studies are required to assess the wider benefit and provide guidance for future changes in screening policy. Until more data from the vaccine programmes are available and, in countries that do not have such programmes secondary prevention methods will need to be the mainstay of efforts to reduce cervical cancer. These secondary methods involve screening for the detection of abnormal or precancerous cell changes (i.e. any changes which may precede, be associated with or carry a significant risk of developing cancer).

\section{Description of the intervention}

\section{Screening}

The Papanicolau, or Pap smear, screening test is used world-wide and is primarily aimed at detecting pre-cancerous changes within the cervix (i.e. abnormalities in the cells of the cervix known as dysplasia) before they have an opportunity to progress to invasive carcinoma. More than $90 \%$ of cervical cancers develop within a small area of the cervix known as the transformation zone and disease progression from dysplasia to invasive cancer is usually slow, therefore providing the opportunity to detect and treat pre-cancerous disease. During a smear test, cells within the external and 
internal layers of the transformation zone (i.e. ecto- and endo- cervical cells) are collected and subsequently examined for abnormal cytological changes. The reliability of the technique is however dependent both on the expertise of the health professional taking the smear and the individual examining the smear. Even in the best laboratories, 5 to $15 \%$ of abnormal smears may be reported as normal (Nottingham 1998). More recently the use of liquid based cytology (LBC) has reduced the number of inadequate smears and subsequent need for recalls (Moss 2004; NICE 2003).

Since the cervical cancer screening programme in 1988, the associated mortality rate in females under 35 years in the United Kingdom has fallen (Peto 2004).

World-wide, great variation exists between countries in terms of the coverage and uptake of cervical cancer screening. In a number of countries including the UK, Finland, Australia, Sweden and Spain, national cervical cancer screening programmes have been introduced. Such screening programmes are usually aimed at those women most at risk of developing cervical cancer (i.e. usually women aged between 20 and 65 years). Recommendations vary between countries, but women are usually screened every one to five years. In many other countries Pap smear services are provided on a much more local basis, if at all.

Pap smear uptake and coverage not only vary between countries, but differences also exist within countries between different sociodemographic groups, according to factors including ethnic origin, age, education and socio-economic status. Lower uptake rates have been found to occur in those women who are older, less welleducated, from lower socio-economic groups or who reside in rural locations (Brinton 1994; Ries 1999). Certain ethnic groups have also been identified as having lower rates of Pap smear uptake, such as African-American, Hispanic and Native American in the USA and Asian women in the UK (Luke 1996; Miller 1994). In many cases therefore, interventions have been aimed at trying to increase screening amongst these groups of women. Thus there are a number of factors to consider when developing interventions to increase the uptake of Pap smear screening. These factors are likely to differ between developing and developed countries and between individual populations in a country.

\section{Encouraging the uptake of screening}

One of the major obstacles to the success of cervical cancer screening worldwide is the uptake of the programme by women. Understanding the various reasons for women not ever attending a smear or failing to continue in further rounds of screening are difficult to assess. Much work across the world has been undertaken to determine contributing factors, such as cost, anxiety, embarrassment, and fear of cancer. Women from ethnic minorities and deprived sub-groups in the population have shown consistently lower uptake over decades of screening in countries worldwide (Moser 2009; Webb 2004). This may be attributable to health literacy especially since screening literature can include complex concepts. HPV is transmitted sexually and therefore screening and cervical cancer itself can be perceived as a consequence of promiscuity and thus have negative connotations. Encouragingly though, in a recent survey of Muslim Turkish women who mostly accept talking about sex as a taboo, the majority of women felt the recommendations from health workers was the major influence in attending screening and accepting the HPV vaccination for their daughters (Ilter 2010). Given the complex nature of the factors involved a number of interventions have therefore been based on theoretical models of health behaviour, such as the Health Belief Model (Kreuter 1996; Marcus 1992) and the Transtheoretical Model (Rimer 1999). It is important to realise that because of differences between populations, interventions that are effective in one setting may not be as effective in another.

In the UK, websites such as that provided by the NHS Cervical Screening Programme can go some way to trying breaking down barriers to screening. The website provides written, audio and visual resources aimed at answering common concerns, explaining the procedure and explanation of results. Key documents are provided in a translated format covering many languages spoken by the larger minority groups in the UK.

\section{How the intervention might work}

\section{Informed consent}

The main focus of attention of cervical screening programmes is to increase the uptake of cervical screening. However, this must be done in the context of informed consent and understanding of the screening tests. It is recognised that both informed uptake and consent is important since screening can cause harm with inevitable false negatives leading to women being wrongly reassured and false positives resulting in unnecessary anxiety and further investigations and possibly even treatment. In particular, informed uptake needs to be considered especially when topical media coverage, exemplified by the cervical cancer sufferer Jade Goody in the UK, can result in such an increase in women attending screening whether required or not (an increase of 3.6 million women screened in 2008/09 compared to 3.2 million in the previous year) yet the numbers soon fall when the media interest settles (3.3. million women screened in 2009/10). (NHS Information Centre 2010).

\section{Why it is important to do this review}

The incidence of cervical cancer is reduced by $93.5 \%, 92.5 \%$, $90.8 \%, 83.6 \%$ and $64.1 \%$ if women have screening every year, every 2 years, every 3 years, every five years and every 10 years respectively; these screening intervals would mean women having $50,25,16,10$ and 5 smear tests respectively in their lifetime 
(IARC 1986). More recently, through modelling analyses, it has been shown that extending the re-screening interval from one year to every three years results in an average excess risk of about 3 per 100,000 (Sawaya 2003). In the UK women aged 25 to 50 are invited for screening every three years and those aged 50 to 64 every five years. Each year, around 3.5 million women accept screening (NHS Information Centre 2010) and this has been estimated to prevent up to 3900 cases of cervical cancer and save over 4500 lives annually in UK (Peto 2004; Sasieni 1996). However, despite its effectiveness, the uptake rate of cervical cancer screening by eligible women remains stubbornly below $80 \%$ (NHS Information Centre 2010). Information is needed to establish what can be done to increase this uptake rate, particularly in the $20 \%$ of women who are missing out on screening.

\section{O B JECT IVES}

To assess the effectiveness of interventions aimed at women, to increase the uptake, including informed uptake, of cervical cancer screening.

\section{METHODS}

\section{Criteria for considering studies for this review}

\section{Types of studies}

Randomised controlled trials (RCTs) and cluster RCTs of universal, selective or opportunistic cervical cancer screening.

\section{Types of participants}

All women eligible to participate in a cervical cancer screening programme as defined by the entry criteria for that programme. Women due or overdue were all considered for inclusion.

\section{Types of interventions}

All interventions targeted at women who are eligible for screening. Interventions aimed at communities such as mass media campaigns (Grilli 2002) and those aimed at health professionals were excluded as they are considered in other Cochrane reviews. Interventions targeted at health professionals that are covered in other Cochrane reviews include: audit and feedback (Jamtvedt 2006), educational outreach visits (O’Brien 1997), printed educational materials (Freemantle 1997), computer-generated paper reminders (Arditi 2010), manual paper reminders (Romero 2004), on-screen computer reminders (Gordon 1998), and other interventions (Hulscher 2006).

For the sub-group analyses the interventions were categorised as follows (Jepson 2000):

- Invitations

- Invitations to women due for screening (either first round or second round). Does not include women who are overdue for screening. Includes fixed or open appointments, letters, telephone calls, verbal recommendations, prompts and follow-up letters.

- Reminders

○ Reminders to women who are overdue for screening and have not responded to the first round of screening. Includes fixed or open appointments, letters, telephone calls, verbal recommendations, prompts and follow-up letters.

- Education

- Educational interventions aiming to increase knowledge of the screening programme or the disease being screened for, that do not contain a counselling component. Includes printed educational materials, audio-visual materials, group and individual teaching and home visits.

- Message Framing

- Messages about screening (either verbal or written) that are framed either positively or negatively.

- Counselling

- Counselling either face-to-face or on the telephone. Must involve a discussion of barriers to screening as well as an educational component.

- Risk Factor Assessment

$\circ$ Risk factor questionnaires and computer programmes assessing a person's risk status.

- Procedures

○ Interventions to increase screening uptake by making the screening procedure easier or more acceptable to individuals undergoing screening. Includes different screening tests for the same disease, or length of time that screening test takes, and opportunistic testing and notification of results.

- Economic

- Removal of financial barriers or economic incentives. Includes reduced cost or free screening tests, transport costs, free postage for returning tests and 'rewards' for completion of a screening test.

\section{Controls}

- Control groups are those with no intervention or no intervention other than that routinely undertaken by the local screening program.

\section{Types of outcome measures}

Trials that reported one or more of the following primary outcome measures were included: 


\section{Primary outcomes}

- Uptake or non-uptake of cervical screening as recorded by health service records (such as screening administration system, hospital or primary care physician records)

- Uptake or non-uptake of cervical screening as collected via self-report (i.e. directly reported by the participant in a telephone interview or questionnaire)

\section{Secondary outcomes}

The following intermediate and other outcomes were considered, if reported:

- Booking of appointments;

- Reported intentions to attend screening;

- Attitudes to screening;

- Knowledge of screening;

- Satisfaction with screening service;

- Costs of the interventions.

\section{Search methods for identification of studies}

Papers in all languages were sought and translations carried out when necessary.

\section{Electronic searches}

See: Cochrane Gynaecological Cancer Group methods used in reviews.

The following electronic databases were searched:

The Cochrane Central Register of Controlled Trials (CENTRAL), Issue 1, 2009. Cochrane Gynaecological Cancer Collaborative Review Group's Trial Register MEDLINE (1966 to March 2009), EMBASE (1985 to March 2009) and LILACS.

The MEDLINE, EMBASE, CENTRAL and LILACS search strategies aiming to identify RCTs comparing interventions targeted at women to encourage the uptake of cervical screening before March 2009 are presented in Appendix 1, Appendix 2, Appendix 3 and Appendix 4 respectively.

Databases were searched from January 1966 until March 2000 in the original review (based on the comprehensive search strategy developed for the HTA review (Jepson 2000)) and up to March 2009 in this updated version.

All relevant articles found were identified on PubMed and using the 'related articles' feature, a further search was carried out for newly published articles.

\section{Searching other resources}

\section{Unpublished and Grey literature}

Metaregister, Physicians Data Query, www.controlled-trials.com/ rct, www.clinicaltrials.gov and www.cancer.gov/clinicaltrials were searched for ongoing trials. The main investigators of the relevant ongoing trials were contacted for further information, as were the major co-operative trials groups active in this area.

Published and unpublished studies were included, if they met the inclusion criteria for the review.

\section{Reference lists and Correspondence}

The citation lists of included trials were checked and experts in the field contacted to identify further reports of trials.

\section{Data collection and analysis}

\section{Selection of studies}

All titles and abstracts retrieved by electronic searching were downloaded to the reference management database (Endnote), duplicates were then removed and the remaining references examined by four review authors (TE, AB, YLW, MK) independently. Those studies which clearly did not meet the inclusion criteria were excluded and copies of the full text of potentially relevant references were obtained. The eligibility of retrieved papers was assessed independently by two review authors (TE, MG). Disagreements were resolved by discussion between the two review authors and when necessary by a third review author (AB). Reasons for exclusion are documented.

\section{Data extraction and management}

For included trials, the following data were abstracted:

- Author, year of publication and journal citation (including language)

- Country

- Setting

- Inclusion and exclusion criteria

- Study design, methodology

- Study population

- Total number enrolled

- Patient characteristics

$\circ$ Age

- Total number of intervention groups

- Intervention details

- Type of intervention

- Description of intervention

- Frequency and duration of intervention

- Type of healthcare professional who provided the intervention

- Control details 
- Any other reported information other than no active intervention was given

- Risk of bias in study (see below)

- Duration of follow-up

- Outcomes - Uptake or non-uptake of cervical screening, booking of appointments, reported intentions to attend screening, attitudes to screening, knowledge of screening, satisfaction with screening service, costs of the interventions.

- For each outcome: Outcome definition;

- Unit of measurement (if relevant);

- For scales: upper and lower limits, and whether high or low score is good;

- Results: Number of participants allocated to each intervention group;

- For each outcome of interest: Sample size; Missing participants.

Data on outcomes were extracted as below:

- For dichotomous outcomes (e.g. Uptake or non-uptake), we extracted the number of women in each treatment arm who underwent screening for cervical cancer and the number of women assessed at endpoint, in order to estimate a risk ratio.

Where possible, all data extracted were those relevant to an intention-to-treat analysis, in which participants were analysed in groups to which they were assigned.

The time points at which outcomes were collected and reported was noted.

Data were abstracted independently by two reviewers (TE, AB) onto a data abstraction form specially designed for the review.
Differences between reviewers were resolved by discussion.

\section{Assessment of risk of bias in included studies}

The risk of bias in included RCTs was assessed using the Cochrane Collaboration's tool. This included assessment of:

- sequence generation

- allocation concealment

- blinding (Assessment of blinding was restricted to blinding of outcome assessors)

- incomplete outcome data: We recorded the proportion of participants whose outcomes were not reported at the end of the study and noted whether loss to follow-up was not reported. We coded a satisfactory level of loss to follow-up for each outcome as:

- $\quad$ Yes, if fewer than $20 \%$ of patients were lost to followup and reasons for loss to follow-up were similar in both treatment arms

- No, if more than $20 \%$ of patients were lost to followup or reasons for loss to follow-up differed between treatment arms

- Unclear if loss to follow-up was not reported

- selective reporting of outcomes

- other possible sources of bias

The risk of bias tool was applied independently by two review authors (TE, AB) and differences resolved by discussion. Results are presented in both a risk of bias graph and a risk of bias summary (See Figure 1; Figure 2). Results of meta-analyses were interpreted in light of the findings with respect to risk of bias.

Figure I. Methodological quality graph: review authors' judgements about each methodological quality item presented as percentages across all included studies.

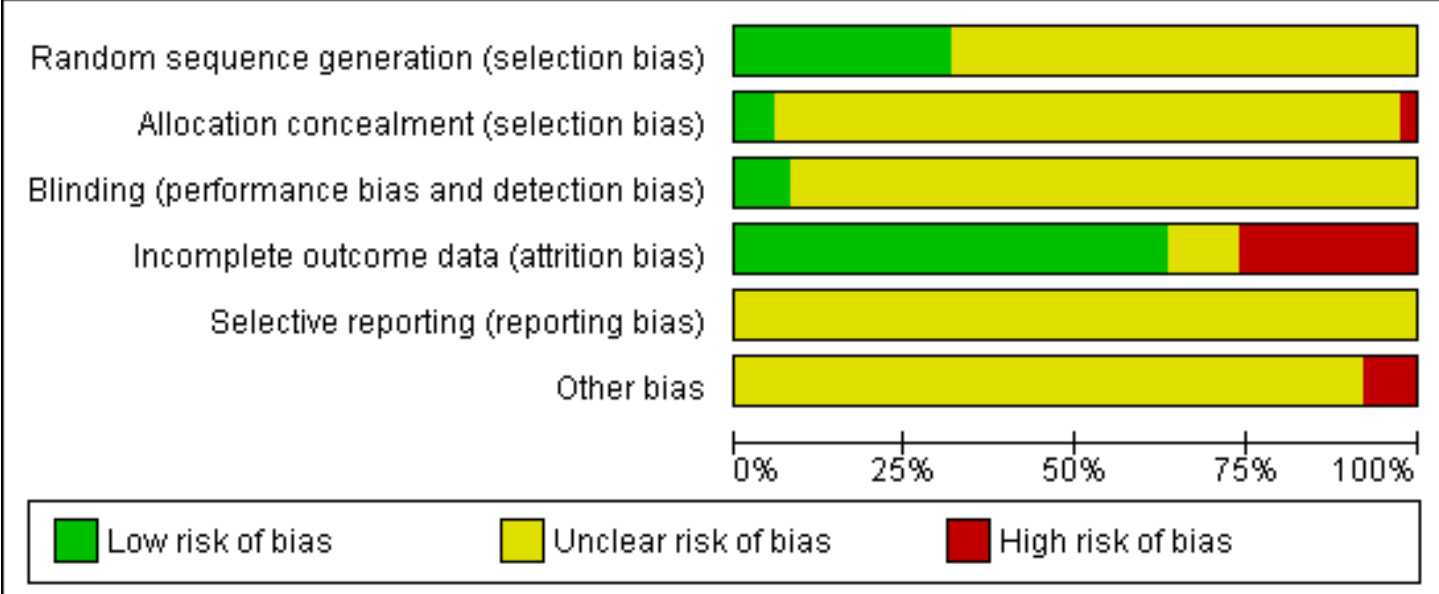


Figure 2. Methodological quality summary: review authors' judgements about each methodological quality item for each included study.

\begin{tabular}{|c|c|c|c|c|c|c|}
\hline & 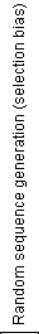 & 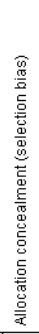 & 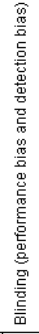 & 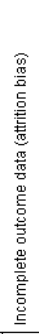 & 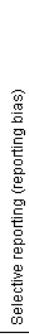 & 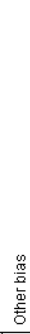 \\
\hline Adab 2003 & † & $?$ & ? & $\odot$ & $?$ & ? \\
\hline Allen 2001 & $?$ & $?$ & $?$ & ○ & $?$ & ? \\
\hline Binstock 1997 & $?$ & $?$ & $?$ & $\odot$ & $?$ & $?$ \\
\hline Bowman 1995 & $?$ & $?$ & $\odot$ & ○ & $?$ & ? \\
\hline Buehler 1997 & + & $?$ & ? & $\odot$ & $?$ & ? \\
\hline Burack 1998 & $\odot$ & $?$ & $?$ & ○ & $?$ & ? \\
\hline Burack 2003 & $?$ & $?$ & $?$ & + & ? & ? \\
\hline Byles 1994 & $?$ & $?$ & ? & $?$ & ? & ? \\
\hline Byles 1995 & $?$ & $?$ & $?$ & ? & $?$ & ? \\
\hline Byles 1996 & ? & $?$ & ? & $?$ & $?$ & ? \\
\hline Clement 1990 & + & $\theta$ & $?$ & $\odot$ & $?$ & ? \\
\hline Del Mar 1998 & $?$ & $?$ & + & + & $?$ & ? \\
\hline Eaker 2004 & $?$ & + & $?$ & (†) & $?$ & ? \\
\hline Greene 1999 & $?$ & $?$ & $?$ & $?$ & $?$ & ? \\
\hline Hunt 1998 & (†) & $?$ & $\odot$ & 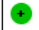 & $?$ & $?$ \\
\hline Kreuter 1996 & $?$ & $?$ & $?$ & ○ & $?$ & ? \\
\hline Lancaster 1992 & $?$ & $?$ & $?$ & 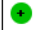 & $?$ & $?$ \\
\hline McAvoy 1991 & † & $?$ & $?$ & ๑) & $?$ & ? \\
\hline McDowell 1989 & $?$ & $?$ & $?$ & † & $?$ & ? \\
\hline Mock 2007 & $?$ & $?$ & $?$ & $\odot$ & $?$ & e \\
\hline Morrell 2005 & $?$ & $?$ & $?$ & $\odot$ & $?$ & ? \\
\hline Navarro 1995 & $?$ & $?$ & $?$ & (2) & ? & ? \\
\hline Ornstein 1991 & $?$ & $?$ & $?$ & ๑ & $?$ & ? \\
\hline Oscarsson 2007 & + & $?$ & $?$ & (- & $?$ & $?$ \\
\hline Pierce 1989 & $?$ & $?$ & $?$ & 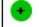 & $?$ & $?$ \\
\hline Pritchard 1995 & + & $?$ & $?$ & 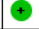 & $?$ & ? \\
\hline Rimer 1999 & $?$ & $?$ & $?$ & (2) & $?$ & ? \\
\hline Risi 2004 & $?$ & $?$ & $?$ & + & $?$ & ? \\
\hline Rivers 2005 & (†) & $?$ & $?$ & ( & $?$ & e \\
\hline Robson 1989 & † & $?$ & $?$ & $\odot$ & ? & e \\
\hline Segnan 1998 & † & $?$ & $?$ & 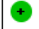 & ? & ? \\
\hline Somkin 1997 & $?$ & $?$ & $?$ & $\odot$ & ? & ? \\
\hline Stein 2005 & † & $?$ & $?$ & ○ & $?$ & ? \\
\hline Sung 1997 & $?$ & $?$ & $?$ & O & $?$ & ? \\
\hline Taylor 2002 & $?$ & $?$ & $?$ & $\odot$ & ? & ? \\
\hline Vogt 2003 & $?$ & $?$ & $?$ & ○ & $?$ & $?$ \\
\hline Ward 1991 & ? & $?$ & $?$ & $\odot$ & $?$ & ? \\
\hline Wilson 1987 & $?$ & + & $?$ & + & ? & ? \\
\hline
\end{tabular}




\section{Measures of treatment effect}

We used the following measures of the effect of treatment:

- For dichotomous outcomes (e.g. uptake or non-uptake), we used the risk ratio

\section{Dealing with missing data}

We did not impute missing outcome data for the primary outcome. If data were missing or only imputed data were reported we contacted trial authors to request data on the outcomes only among participants who were assessed.

\section{Assessment of heterogeneity}

Heterogeneity between trials was assessed by visual inspection of forest plots, by estimation of the percentage heterogeneity between trials which cannot be ascribed to sampling variation (Higgins 2003), by a formal statistical test of the significance of the heterogeneity (Deeks 2001) and, if possible, by sub-group analyses (see below). If there was evidence of substantial heterogeneity, the possible reasons for this were investigated and reported.

\section{Assessment of reporting biases}

Funnel plots corresponding to meta-analysis of the primary outcome were examined to assess the potential for small study effects. When there was evidence of small-study effects, publication bias was considered as only one of a number of possible explanations. If these plots suggested that treatment effects may not be sampled from a symmetric distribution, as assumed by the random effects model, sensitivity analyses were performed using fixed effects models.

\section{Data synthesis}

If sufficient, clinically similar studies were available their results were pooled in meta-analyses.

- For dichotomous outcomes, the risk ratios were pooled.

For trials with multiple treatment groups, the 'shared' comparison group was divided into the number of treatment groups and comparisons between each treatment group and the split comparison group were treated as independent comparisons.

A random effects model with inverse variance weighting was used for all comparisons (DerSimonian 1986).

Where interventions differed to any degree or there was other substantial heterogeneity the results were reported in a narrative. For cluster randomised controlled trials, if the analysis accounted for the cluster design then a direct estimate of the desired treatment effect was extracted e.g. RR plus $95 \%$ CI. If the analysis did not account for the cluster design, we extracted the number of clusters randomised to each intervention, the average cluster size in each intervention group and the outcome data, ignoring the cluster design, for all women in each group. Next, using an external estimate of the intracluster coefficient (ICC) a design effect was estimated. Hence, the variance of the effect estimate was inflated. It was then possible to enter the data into RevMan 5 and combine the cluster randomised trials with individually randomised trials in the same meta-analysis, using the generic inverse variance method of metaanalysis.

\section{Subgroup analysis and investigation of heterogeneity}

Subgroup analyses were performed according to the different categories of intervention type.

\section{Sensitivity analysis}

We intended to repeat the meta-analyses excluding: trials at high risk of bias; and examine very large trials separately to determine their overall influence. However, all trials were at moderate or high risk of bias so consequently we did not perform sensitivity analyses.

\section{RES U L T S}

\section{Description of studies}

See: Characteristics of included studies; Characteristics of excluded studies.

\section{Results of the search}

Over 46,000 titles and abstracts (where available) were screened for the original HTA review covering all screening tests, of which 440 full paper copies were then further assessed for inclusion in the original review. For the review update, a further 1886 titles and abstracts were screened and 78 full paper copies were then further assessed. Forty-two of these papers, specifically focused on cervical cancer screening and appeared to fulfil the inclusion criteria. In order to confirm that trials met the inclusion criteria for analysis, additional information was requested from the authors of 42 trials (37 authors). Replies were received from 20 of the trials (17 authors). In total 102 articles were retrieved in full and translated into English where appropriate and up-dated versions of relevant trials were identified. The full text screening of these 102 references excluded 64 of them for the reasons described in the table 
Characteristics of excluded studies. However 38 completed RCTs were identified that met our inclusion criteria and are described in the table Characteristics of included studies.

In total thirty eight trials, randomising a total of 159,728 women, met all of the inclusion criteria and were included in this review.

\section{Included studies}

(See Characteristics of included studies)

Thirty-eight RCT's were included in the review, including six cluster RCTs (Byles 1994; Byles 1995; Byles 1996; Mock 2007; Navarro 1995; Ornstein 1991. Sixteen of the trials were performed in the USA (Allen 2001; Binstock 1997; Burack 1998; Burack 2003; Clementz 1990; Greene 1999; Kreuter 1996; Mock 2007; Navarro 1995; Ornstein 1991; Rimer 1999; Rivers 2005; Somkin 1997; Sung 1997; Taylor 2002; Vogt 2003), nine in Australia (Bowman 1995; Byles 1994; Byles 1995; Byles 1996; Del Mar 1998; Hunt 1998; Morrell 2005; Pritchard 1995; Ward 1991), seven in the UK (Adab 2003; Lancaster 1992; McAvoy 1991; Pierce 1989; Robson 1989; Stein 2005; Wilson 1987), two in Canada (Buehler 1997; McDowell 1989), two in Sweden (Eaker 2004; Oscarsson 2007), one in South Africa (Risi 2004) and one in Italy (Segnan 1998). The majority of the trials were set in community clinics and primary care practices. However, five of the trials based in the USA were set in Health Maintainance Organisations (HMOs) (Binstock 1997; Burack 1998; Burack 2003; Somkin 1997; Vogt 2003), and two of the UK trials were based around the UK national cervical screening programme (McAvoy 1991; Wilson 1987). The trial set in Italy was also based around a national cervical screening program (Segnan 1998). In addition five trials were aimed at specific ethnic populations including Asian women (McAvoy 1991), Afro-American women (Sung 1997), Vietnamese-American women (Mock 2007), Chinese women (Taylor 2002) and Latinas (Navarro 1995). Twentyone trials had more than two arms (Binstock 1997; Bowman 1995; Burack 1998; Byles 1994; Byles 1995; Byles 1996; Greene 1999; Hunt 1998; Kreuter 1996; McAvoy 1991; McDowell 1989; Ornstein 1991; Pierce 1989; Pritchard 1995; Rimer 1999; Rivers 2005; Segnan 1998; Somkin 1997; Stein 2005; Taylor 2002; Vogt 2003); the remaining seventeen trials had only two arms and thus just one comparison.

\section{Invitations}

Seventeen trials evaluated the effectiveness of invitation letters (Binstock 1997; Byles 1994; Byles 1995; Byles 1996; Bowman 1995; Buehler 1997; Burack 1998; Clementz 1990; Del Mar 1995; Hunt 1998; Lancaster 1992; McDowell 1989; Ornstein 1991; Pierce 1989; Pritchard 1995; Segnan 1998; Wilson 1987). The trials were subdivided according to the invitation type (i.e. GP letter, letter from another authority source, face-to-face invitation, open invitation and invitation with fixed appointment).
Comparison groups included different types of invitation or a control group (usually consisting of usual care or no intervention). Two trials ( $\mathrm{n}=4370$ participants in total) evaluated invitations from different authority sources (Bowman 1995; Segnan 1998), and the use of letters with appointments to attend for screening; two additional studies also evaluated the use of letters with appointments (Pritchard 1995; Wilson 1987). Three trials ( $\mathrm{n}=3086$ participants in total) examined the use of letter with open invitations to make appointments versus control (usual care) (Bowman 1995; Pritchard 1995; Somkin 1997).

Two trials looked at telephone invitations ( $\mathrm{n}=5652$ participants in total) (Binstock 1997; McDowell 1989), whereas another study ( $\mathrm{n}=121$ participants in total) looked at face-to-face invitations from a health worker or GP (Hunt 1998).

\section{Education}

Three trials evaluated printed materials (McAvoy 1991; Bowman 1995; Rimer 1999), two were face-to-face home visit trials (McAvoy 1991, Sung 1997) and one trial ( $n=176$ participants) did not report in detail the type of educational intervention used (Greene 1999). One cluster randomised trial adequately accounted for the clustering in its analyses, but the data reported was not suitable for calculating risk ratios (Navarro 1995).

\section{Counselling}

Two trials examined the use of counselling ( $\mathrm{n}=599$ participants in total). One compared face-to-face counselling by a GP with no counselling (Ward 1991); the other compared telephone counselling and patient prompts, versus patient prompts alone (control group) and provider prompts alone (Rimer 1999).

\section{Risk Factor Assessment}

Two trials ( $\mathrm{n}=1590$ in total) evaluated risk factor assessment (Greene 1999; Kreuter 1996). Both used an enhanced risk factor assessment that involved a personally tailored assessment and discussion with the health care provider about the woman's personal risk factors for developing cervical cancer. Both interventions were based on theoretical models of behaviour, the Social Cognitive Theory and Motivational Interviewing Methods (Greene 1999) and the Health Belief Model (Kreuter 1996), with a view to changing behaviour to increase the uptake of Pap smears. One trial (Greene 1999) compared the intervention $(\mathrm{n}=97)$ to usual care $(\mathrm{n}=79)$ whereas the other trial (Kreuter 1996) $(\mathrm{n}=1317,206 /$ 1317 analysed) compared the intervention to a no intervention control group (Kreuter 1996). Similarly, this trial also compared enhanced risk factor assessment with a less intense 'typical' risk factor assessment. The typical risk factor assessment involved supplying the participant with their personal risk factor information but not discussing the information provided. 


\section{Procedures}

Only one procedure was identified; access to a health prevention nurse (Robson 1989). There were two quasi-RCTs that examined the uptake of screening where the gender of the smear taker was revealed in the invitation letter and access to a lay health worker who offered women screening with a female nurse practitioner (Hicks 1997; Margolis 1998), but no RCTs were found.

\section{Secondary outcomes}

A summary of the data relating to secondary outcomes is presented in Table 1.

One trial ( $\mathrm{n}=273$ ) used the booking of appointments for screening as an outcome measure (Greene 1999).

One trial $(\mathrm{n}=3094)$ examined participants attitudes to Pap smear screening (Byles 1995).

Five trials $(\mathrm{n}=7718$ participants in total) presented cost data (Binstock 1997; McDowell 1989; Oscarsson 2007; Stein 2005; Vogt 2003). Many of the trials used multiple intervention groups but only those groups that used an intervention aimed at women (and not healthcare providers) were included in this review.

\section{Excluded studies}

The sixty-four references excluded after assessing full paper copies are listed in the Characteristics of excluded studies table, with reasons for their exclusion. Fifteen were quasi randomised (Baele 1998; Chumworathayi 2007; Hicks 1997; Hou 2002; Hou 2005; Lantz 1995; Lantz 1996; Levine 2003; Marcus 1992; Margolis 1998; Maxwell 2003; Park 2005; Paskett 1990; Ward 1999; Yancey 1995), three studies included participants who may have been screened before receiving the intervention (Dignan 1996; Dignan 1998; Gotay 2000), ten studies used an intervention aimed at either the physician or both the physician and patient (Boissel 1995; Bonevski 1999; Campbell 1997; Cecchini 1989; Hillman 1998; Litzelman 1993; Manfredi 1998; Nguyen 2000; Roetzheim 2004; Roetzheim 2005), seven studies used an intervention or an outcome that was not strictly concerned with increasing uptake (Brewster 2002; Del Mar 1995; Holloway 2003; Katz 2007; Paul 2003; Philips 2006; Sankaranarayanan 2003;), nine studies concerned intervention aimed at improving followup of an abnormal smear results rather than initial Pap screening uptake (Engelstad 2005; Lauver 1990; Marcus 1998; Miller 1999; Paskett 1995; Peters 1999; Stewart 1994; Takacs 2004; Tomlinson 2004), four studies presented in a way that was not usable for the purposes of the review (Corkrey 2005; Hancock 2001; Lynch 2004; Newell 2002), three studies were excluded they included women over the upper age limit of most routine cervical screening programmes (Mayer 1992; Ruffin 2004; Valanis 2003) two studies did not separate attendance for cervical cancer screening from other screening tests (Mitchell 1991; Powers 1992) and ten studies did not use a randomised design (Al Saifafi 2009; German 1995;
Jenkins 1999; Karwalajtys 2007; Miller 2007; Mitchell 1997; Paskett 1999; Perkins 2007; Shelley 1991; Torres-Mejia 2000), one study (Lam 2003) presents initial data only that is included elsewhere (Mock 2007). The trial of Peters 1999 was a cluster RCT examining anxiety among women with mild dyskaryosis and the aim of the educational intervention was to reduce anxiety so scope differs to that of this review.

\section{Risk of bias in included studies}

(See Risk of Bias tables in Characteristics of included studies) All trials were at moderate risk of bias: Hunt 1998 satisfied three of the criteria that we used to assess risk of bias, whereas the other trials, at most, satisfied only two of the criteria. Eight trials failed to fulfil any of the criteria adequately (Byles 1994; Byles 1995; Byles 1996; Greene 1999; Kreuter 1996; Navarro 1995; Rimer 1999; Sung 1997).

\section{Allocation}

Twelve trials used an adequate method of generation of the sequence of random numbers to allocate women to treatment arms (Adab 2003; Buehler 1997; Burack 1998; Clementz 1990; Hunt 1998; McAvoy 1991; Oscarsson 2007; Pritchard 1995; Rivers 2005; Robson 1989; Segnan 1998; Stein 2005). The method of randomisation was unclear in the remaining twenty-six trials that did not report the method of randomisation.

In the trial of Eaker 2004 "collaborators in the trial were blinded to the women's group assignment". Concealment of allocation was satisfactory in the trial of Wilson 1987, as this trial used a centralised independent randomisation and allocation service which was protected from any potential tampering by those involved in the study. In the trial of Clementz 1990 treatment allocation was not concealed and was not reported in any of the other thirty-five trials.

\section{Blinding}

The outcome assessor was blinded to the treatment allocation in only three trials (Bowman 1995; Del Mar 1998; Hunt 1998). It was unclear in the remaining thirty-five trials whether the outcome assessor was blinded as it was not reported.

\section{Incomplete outcome data}

Loss to follow up was low in twenty-eight of the trials, with at least $80 \%$ of women being assessed at the end of the study. It was unsatisfactory in ten trials (Allen 2001; Bowman 1995; Burack 1998; Kreuter 1996; Navarro 1995; Rimer 1999; Rivers 2005; Stein 2005; Sung 1997; Vogt 2003), as less than $80 \%$ of women were assessed at endpoint in at least one of the outcomes and was 
unclear in the remaining four trials (Byles 1994; Byles 1995; Byles 1996; Greene 1999).

\section{Selective reporting}

In all thirty-eight trials it was unclear as to whether outcomes had been selectively reported as there was insufficient information to permit judgement.

\section{Other potential sources of bias}

In thirty-five trials there was insufficient information to assess whether any important additional risk of bias existed. The trial of Robson 1989 was potentially biased as it stopped early because participating doctors were not prepared to continue excluding half the practice from access to the health promotion nurse. In Rivers 2005 the women received a telephone call at 6 months to ascertain screening uptake and this may itself have acted as a prompt for non-attenders to attend for screening and as such influenced the 12 month data. Women were selected from the social networks of the lay health outreach workers in Mock 2007 and therefore may be more motivated to comply.

\section{Effects of interventions}

Interventions targeted at women to encourage the uptake of cervical screening (Review)

Copyright (@) 201 I The Cochrane Collaboration. Published by John Wiley \& Sons, Ltd.
We did not include any of the cluster RCTs (Byles 1994; Byles 1995; Byles 1996; Mock 2007; Navarro 1995; Ornstein 1991) in any of the meta analyses because it was either not possible to extract binary data, interventions or/and outcomes differed sufficiently or a satisfactory estimate of the ICC could not be obtained. We obtained values of the ICC that ranged from 0.02 to 0.29 (Hade 2010). When 0.02 was used as the ICC for the trial of Byles 1996 we got an estimated design effect of 109 due to the average cluster size being large, which considerably decreased the effective sample size. Since the unit of randomisation was postal codes we would not expect a large ICC, but do not have estimates from any pilot studies so have reported cluster RCTs as single trial narratives due to the uncertainty in reducing the effective sample size.

\section{Uptake of screening}

\section{Invitations}

\section{Invitation versus control}

A funnel plot corresponding to the invitation versus control subgroup in the above meta-analysis showed no evidence of bias in small studies (see Figure 3). Funnel plots were not computed elsewhere in the analyses as there were insufficient trials in which to draw valid conclusions. Analysis 1.1 
Figure 3. Funnel plot of comparison: I Invitation vs control, outcome: I.I Uptake of screening.

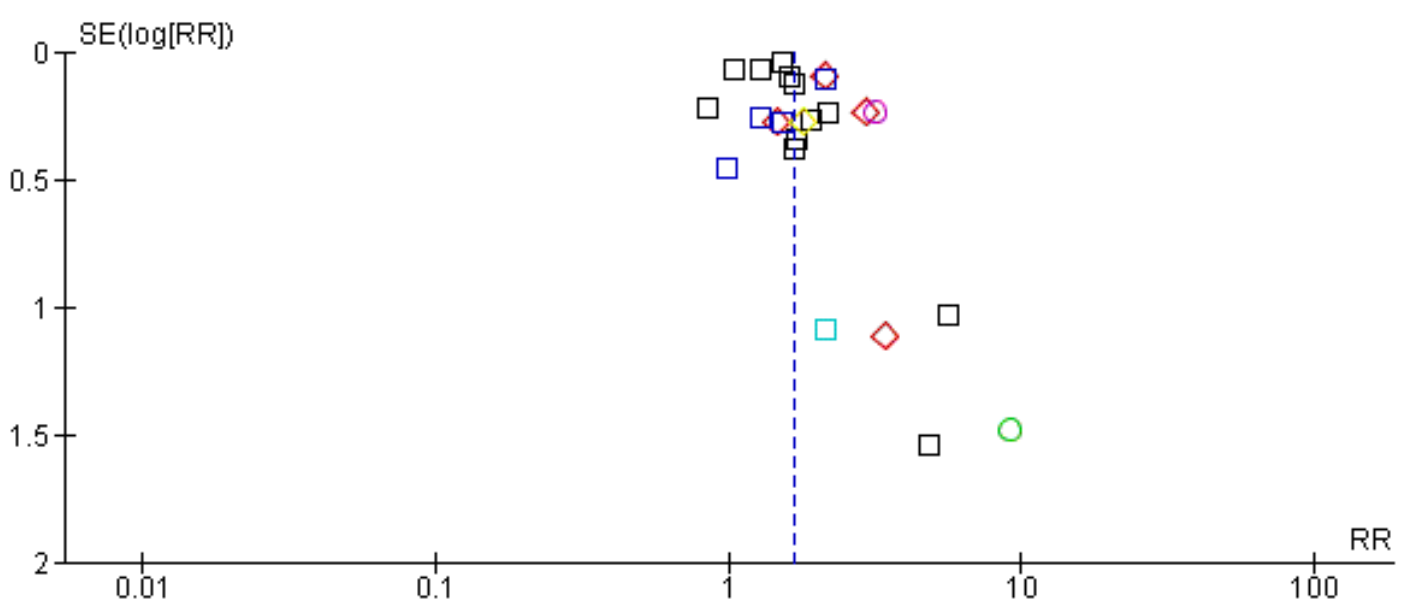

Subgroups

Invitation letter vs control

Telephone invitation ws control

Face to face invitation ws control

Letter with open invitation to make appointment vs control

Letter with fixed appointment vs control

Letter invitation with telephone follow up vs control

Celebrity letter invitation ws control

\section{Invitation letter versus control}

Meta-analysis of twelve trials (Binstock 1997; Bowman 1995; Buehler 1997; Burack 1998; Burack 2003; Del Mar 1998; Hunt 1998; Lancaster 1992; McDowell 1989; Morrell 2005; Pierce 1989; Stein 2005), assessing 99,651 participants, found that women who received invitation letters to attend cervical screening programmes had a significantly higher uptake of screening than women who received usual care or no invitation $(R R=1.44$, 95\% CI: 1.24 to 1.52 ). The percentage of the variability in effect estimates that is due to heterogeneity rather than sampling error (chance) may represent substantial heterogeneity $\left(\mathrm{I}^{2}=72 \%\right)$. (comparison 1.1.1)

\section{Telephone invitation versus control}

Meta-analysis of four trials (Binstock 1997; McDowell 1989; Stein 2005; Vogt 2003), assessing 2342 participants, found that women who received a telephone invitation had a significantly higher uptake of screening than those in the control group $(\mathrm{RR}=$ 2.16, $95 \%$ CI: 1.70 to 2.74 ). The percentage of the variability in effect estimates that is due to heterogeneity rather than chance may represent moderate heterogeneity $\left(\mathrm{I}^{2}=21 \%\right)$. (comparison 1.1.2)

\section{Face to face invitation versus control}

The trial of Hunt 1998, which assessed 121 participants, found no statistically significant difference in the uptake of screening between women who received a face to face invitation and those in the control group ( $R R=9.15$, 95\% CI: 0.50 to 166.30). However, only four out of the 121 women attended for screening. (comparison 1.1.3).

\section{Letter with open invitation to make appointment versus} control

Meta-analysis of four trials (Bowman 1995; Pritchard 1995; Somkin 1997; Vogt 2003), assessing 2998 participants, found that women who received letters with an open invitation to attend a cervical screening programme had significantly higher uptake of cervical screening than women in the control group $(\mathrm{RR}=1.61$, 95\% CI: 1.15 to 2.26 ). The percentage of the variability in effect estimates that is due to heterogeneity rather than chance may represent moderate heterogeneity $\left(\mathrm{I}^{2}=50 \%\right)$.

The cluster RCT of Byles 1996 reported results of a mass mailing campaign to promote screening. The intervention letter provided information on the screening services available in the local area and included an invitation to enrol with the Pap smear reminder 
service. In the intervention arms, women were either sent a personalised letter with the initial invitation or three years later, with the reminder invitation. A control group received no letter at all. Significant increases in screening rates were observed in those receiving a personalised letter with the initial invitation.

Similarly the Byles 1995 cluster RCT assessed the effectiveness of two direct mail strategies to encourage women to have Pap smears compared to a control. The two strategies were assessed in two geographically separated postal regions in Australia. The first intervention consisted of a personally addressed letter providing basic information about Pap smears, information on screening, advice, lists of local providers and an invitation to enrol with free Pap reminder service. The second intervention, in addition to the letter, included a multi-faceted intervention package designed to address a number of factors associated with screening behavior. The effectiveness of each strategy was assessed using a multiple group time-series design involving three postal regions. Both interventions resulted in statistically significant increases in attendances for screening over the post intervention period $(42.2 \%$ in the region receiving the simple prompt and $39.6 \%$ in the region receiving the multi-faceted approach).

The cluster RCT of Ornstein 1991 assessed the effectiveness of three interventions that aimed to encourage uptake of various screening/vaccine sessions, including a Pap smear. Patients and their physicians were randomly assigned by practice group into one of four groups which included physician reminders, patient reminders, patient and physician reminders and a control group. The authors concluded that computer based physician and patient reminder systems improved adherence to preventive services in primary care settings. In this one year study, a statistically significant decline in Pap smear adherence was confined to the physician reminder group. Small, inconsistent declines in adherence occurred in all four groups. These declines were significant only for white women. (comparison 1.1.4).

\section{Letter with fixed appointment versus control}

In the trial of Pritchard 1995, which assessed 177 participants, women who received letters with a fixed appointment to attend a cervical screening programme had a significantly higher uptake of screening than the control group $(\mathrm{RR}=1.80,95 \% \mathrm{CI}: 1.04$ to 3.11). (comparison 1.1.5).

\section{Letter invitation with telephone follow up versus control}

The trial of Vogt 2003, which assessed 276 participants, found a significant difference in the uptake of screening between women who received a face to face invitation and those in the control group ( $\mathrm{RR}=3.14$, 95\% CI: 1.97 to 5.01). (comparison 1.1.6).

\section{Celebrity invitation versus control}

The trial of Stein 2005 which assessed 316 participants, found no statistically significant difference in the uptake of screening between women who received a celebrity endorsed letter of invitation and those in the control group $(\mathrm{RR}=2.15,95 \% \mathrm{CI}: 0.25$ to 18.15). (comparison 1.1.7)

\section{GP invitation letter versus invitation letter from other authority sources}

The trial of Bowman 1995, which assessed 86 participants, found little difference between GP invitation letters and health clinic invitation letters in the uptake of cervical screening $(R R=1.69$, 95\% CI: 0.75 to 3.82 ).

In the trial of Segnan 1998, which assessed 4028 participants, women who received GP letters to attend a cervical screening programme had a significantly higher uptake of screening than those who received invitation letters from programme coordinators (RR $=1.13,95 \%$ CI: 1.05 to 1.21$)$. Analysis 2.1

\section{Personal invitation versus invitation letter}

Meta-analysis of two trials (Binstock 1997; McDowell 1989), assessing 1899 participants, found that women who received telephone invitations to attend a cervical screening programme had a significantly higher uptake of screening than women given invitation letters ( $R R=1.32,95 \% \mathrm{CI}: 1.15$ to 1.53 ). The percentage of the variability in effect estimates that is due to heterogeneity rather than chance is not important $\left(\mathrm{I}^{2}=0 \%\right)$.

The trial of Hunt 1998, which assessed 123 participants, found no statistically significant difference between face to face invitations and invitation letters in the uptake of cervical screening $(\mathrm{RR}=$ 2.10, $95 \%$ CI: 0.40 to 11.05 ). Analysis 3.1

\section{Letter with fixed appointment versus letter with open invitation to make an appointment}

Meta-analysis of four trials (Bowman 1995; Pritchard 1995; Segnan 1998; Wilson 1987), assessing 4706 participants, found that women who were given letters with a fixed appointment to attend a cervical screening programme had a significantly higher uptake of screening than women who received letters with an open invitation ( $\mathrm{RR}=1.57,95 \% \mathrm{CI} 1.43$ to 1.72 ). The percentage of the variability in effect estimates that is due to heterogeneity rather than chance is not important $\left(\mathrm{I}^{2}=0 \%\right)$. Analysis 4.1

Three way comparison of television media, television media combined with invitation letter and television media combined with GP based recruitment

The cluster RCT of Byles 1994 assessed the effectiveness of three community based strategies to promote screening for cervical cancer. A trial of each television media intervention was carried out in three postal regions in New South Wales - a rural locality, a 
country town and a major rural centre. Three control regions were selected to be demographically similar to the corresponding regions. Television media alone was associated with a significant increase in attendances for screening in the rural centre. The media/ letter based campaign was associated with a significant increase in attendances in the rural locality and rural centre. The media/GP based campaign was associated with significant increases in attendances in all three regions. All three interventions were associated with significant increases in the number of women attending for screening above those observed in the control regions. Furthermore, these increases were not restricted to women at low risk. They were also found for older women (aged 50 to 69 years) and women who had not had a Pap smear within the past three years.

\section{Education}

\section{Education versus control}

\section{Education (printed material) versus control}

Meta-analysis of three trials (Bowman 1995; McAvoy 1991; Rimer 1999), assessing 502 participants, showed little difference in the uptake of screening between women who received printed material as a form of education and those in the control group $(\mathrm{RR}=1.11$, $95 \%$ CI: 0.88 to 1.41$)$. The percentage of the variability in effect estimates that is due to heterogeneity rather than chance is not important $\left(\mathrm{I}^{2}=0 \%\right)$. Analysis 5.1

\section{Education (miscellaneous) versus control}

Meta-analysis of two trials (Greene 1999; Taylor 2002), which assessed 295 participants showed a significantly higher uptake of screening in women in the education group compared to women in the control group ( $\mathrm{RR}=1.92,95 \% \mathrm{CI} 1.24$ to 2.97 ). The percentage of the variability in effect estimates that is due to heterogeneity rather than chance is not important $\left(\mathrm{I}^{2}=0 \%\right)$. Women were given an educational exercise (format unknown) (Greene 1999) or a variety of educational materials (Taylor 2002), aimed at increasing awareness of cervical screening programme (comparison 5.1.2).

\section{Education (miscellaneous) versus control}

Meta-analysis of three trials (McAvoy 1991; Sung 1997; Taylor 2002), assessing 1318 participants, showed a significantly higher uptake of screening in women who received face to face home visits as a form of education compared to those in the control group ( $\mathrm{RR}=2.33,95 \% \mathrm{CI}: 1.04$ to 5.23$)$. The percentage of the variability in effect estimates that is due to heterogeneity rather than chance may represent considerable heterogeneity $\left(\mathrm{I}^{2}=79 \%\right)$ (comparison 5.1.3).

\section{Education versus other}

The trial of Bowman 1995, which assessed 99 participants, showed little difference in the uptake of screening between women who received printed material as a form of education and those who received a health clinic invitation letter $(\mathrm{RR}=1.08,95 \% \mathrm{CI}: 0.45$ to 2.61). Similarly there was no statistically significant difference in the uptake of screening between printed material and GP invitation letters ( $R R=0.64,95 \% \mathrm{CI}: 0.31$ to 1.32 ).

The trial of Greene 1999, which assessed 98 participants, found little difference in the uptake of cervical screening between education (format unknown) aimed at increasing awareness of cervical screening programme and enhanced risk assessment $(R R=0.87$, 95\% CI: 0.63 to 1.21 ).

The trial of McAvoy 1991, which assessed 482 participants, showed little difference in the uptake of screening between women who received printed material as a form of education and those shown educational videos or slides $(\mathrm{RR}=0.86,95 \% \mathrm{CI}$ : 0.64 to 1.14).

The trial of Allen 2001, which assessed 2944 participants, showed no significant difference in the uptake of screening between women who worked in worksites with workshops aimed at increasing cervical screening led by peer health advisors and those in the non-intervention group ( $\mathrm{RR}=1.02,95 \% \mathrm{CI}: 0.99$ to 1.05$)$. Analysis 6.1

\section{Lay health outreach worker and media education versus media education alone}

In the cluster RCT of Mock 2007, 1005 Vietnamese American women were randomised into either a lay health worker (LHW) outreach plus media based education combined intervention or a media based education only (control). Each LHW used her social network to recruit 20 women before they were randomised. Over the program period, $16 \%$ of women in the combined intervention group obtained a Pap test (increasing from $65.8 \%$ to $81.8 \% ; \mathrm{P}<0.001)$ compared with $5.4 \%$ in the media only group (increasing from $70.1 \%$ to $75.5 \%$; $\mathrm{P}<0.001$ ). The increase in the combined intervention group was significantly greater than that in the media only group $(\mathrm{Z}$ test $\mathrm{P}=0.001)$. Among women who at baseline had never had a Pap test, $46 \%$ of those in the combined intervention group obtained one during the program period $(\mathrm{P}<0.001)$ compared with $27 \%$ of those in the media only group $(\mathrm{P}<0.001)$. Again, the increase was significantly greater in the combined intervention group $(\mathrm{Z}$ test $\mathrm{P}=0.001)$. In the combined intervention group, $21.6 \%$ became up-to-date during the program period (increasing from $45.7 \%$ to $67.3 \%$; $\mathrm{P}<0.001$ ) compared with $4.8 \%$ in the media only group (increasing from $50.9 \%$ to $55.7 \%$; $\mathrm{P}=0.035$ ). The increase in being up-to-date was also significantly greater in the combined intervention group $(\mathrm{Z}$ test $\mathrm{P}=0.001$ ) (Analysis 6.2). 


\section{Standard invitation and printed education versus standard} invitation only

The trial of Eaker 2004, which assessed 12,157 participants, did not show a significant increase in the uptake of cervical in women who received both standard invitation and printed education material compared to women who received the standard invitation to attend screening ( $\mathrm{RR}=1.05,95 \% \mathrm{CI}: 0.99$ to 1.11$)$. Analysis 6.3

\section{2 week cancer screening education versus control}

In the cluster RCT of Navarro 1995, 36 lay community workers (consejeras) were recruited and trained to conduct educational group sessions. Each consejera recruited approximately 14 peers from the community to participate in the program. The consejeras were randomly assigned to either a 12 week cancer screening intervention group or a control group. The authors reported although both groups increased Pap smear use, the increase was higher for the cancer intervention group than the control group. The difference approached statistical significance using participants as the unit of analysis $(P=0.10)$, but not when consejera was the unit of analysis $(\mathrm{P}=0.37)$.

\section{Counselling}

\section{Counselling versus control}

Meta-analysis of two trials (Rimer 1999; Ward 1991), assessing 393 participants, found that women given counselling to encourage attendance of a cervical screening programme had a significantly higher uptake of screening than those given no counselling or patient prompts alone ( $\mathrm{RR}=1.23,95 \% \mathrm{CI}: 1.04$ to 1.45 ). The percentage of the variability in effect estimates that is due to heterogeneity rather than chance is not important $\left(\mathrm{I}^{2}=0 \%\right)\left(\mathrm{I}^{2}=\right.$ 0\%). Analysis 7.1

\section{Counselling versus other}

The trial of Rimer 1999, assessing 208 participants, found little difference in the uptake of cervical screening between women who received telephone counselling aimed at increasing awareness of cervical screening programme and women who received provider prompts $(\mathrm{RR}=1.13,95 \% \mathrm{CI}: 0.90$ to 1.41$)$. Analysis 8.1

\section{Risk Factor Assessment}

\section{Enhanced risk assessment versus control}

Meta-analysis of two trials (Greene 1999; Kreuter 1996), assessing 145 participants, showed little difference in the uptake of screening between women who had an enhanced risk assessment and those in the control group ( $\mathrm{RR}=1.52,95 \% \mathrm{CI}: 0.58$ to 3.95$)$. The percentage of the variability in effect estimates that is due to heterogeneity rather than chance may represent considerable heterogeneity $\left(\mathrm{I}^{2}=87 \%\right)$. The results of the two trials differed markedly where the trial of Greene 1999 showed a statistically significant increase in the number of women screened who received the enhanced risk assessment compared to control $(\mathrm{RR}=2.53$, 95\% CI: 1.42 to 4.51), whereas the Kreuter 1996 trial showed no significant difference between the two groups $(R R=0.95,95 \%$ CI: 0.64 to 1.42 ). Analysis 9.1

\section{Enhanced risk assessment versus other}

The trial of Kreuter 1996, which analysed 70 participants, found no statistically significant difference in the uptake of cervical screening between women who had an enhanced risk assessment and women who received a 'typical' risk assessment $(R R=1.20$, $95 \%$ CI: 0.79 to 1.81 ). Analysis 10.1

\section{Procedures}

\section{Access to health promotion nurse versus control}

The trial of Robson 1989), which assessed 1407 participants, found a significant increase in uptake of screening in women who had access to a health prevention nurse compared to those who did not ( $R R=1.18,95 \% \mathrm{CI}$ : 1.10 to 1.26$)$. There was substantial heterogeneity between trials $\left(I^{2}=76 \%\right)$. Analysis 11.1

\section{Photocomic book}

\section{Photocomic book verus placebo comic book}

Only one trial (Risi 2004) assessing 658 participants studied photocomic book use as a tool to promote cervical screening uptake. It found no significant difference in the uptake of cervical screening between women who had been exposed to the photocomic book aimed at promoting cervical screening uptake compared with women who been exposed to a placebo photocomic book. $(\mathrm{RR}=$ $0.96,95 \%$ CI: 0.53 to 1.73 ). Analysis 12.1

\section{Intensive recruitment}

\section{Intensive recruitment attempts versus control}

One trial (Oscarsson 2007) with 800 participants studied intensive recruitment. A significant increase in cervical screening uptake was found in women in the intensive recruitment intervention group compared with those in the control group $(\mathrm{RR}=1.59,95 \% \mathrm{CI}$ : 1.24 to 2.06 ). Analysis 13.1 


\section{Message framing}

Only one trial (Rivers 2005) assessed message framing in the uptake of cervical screening in 441 participants. No significant differences in uptake were seen. Loss-framed messages whether prevention or detection phrased and gain-framed detection compared to loss-framed detection messages both showed a non-significant decrease in uptake ( $R R=0.79,95 \%$ CI 0.48 to 1.30 ). Gainframed messages whether prevention or detection phrased and gain-framed detection compared to loss-framed prevention messages both showed a non-significant increase in uptake $(R R=1.07$, 95\% CI 0.62 to 1.83$)$. Analysis 14.1

\section{Reminders}

No trials examining the effects of reminders on cervical screening uptake were identified.

\section{Economic}

No trials with economic outcomes were identified.

\section{Informed uptake of cervical screening}

None of the trials identified in this review reported informed consent to cervical screening.

\section{Secondary outcomes}

A summary of the data relating to secondary outcomes is presented in Table 1

\section{Booking of appointments}

One trial ( $\mathrm{n}=273$ ) used the booking of appointments for screening as an outcome measure (Greene 1999). The trial population was randomly divided into three groups: usual care (women received general dietary and health information), cancer education (women received general information about cervical cancer risk factors and screening recommendations), and cognitive behavioural intervention (women received feedback about personal risk for cancer and engaged in a clinical interview to enhance self-efficacy for preventative behaviour). Women in the usual care group were more likely to schedule an appointment for a Pap smear than those who received the cognitive behavioural intervention (usual care $=79 \%$ versus cognitive behavioural intervention $=37 \%, \mathrm{P}<0.0001)$. Women in the usual care group were also more likely to attend without rescheduling the appointment (usual care $=64 \%$ versus cognitive behavioural intervention $=35 \%, \mathrm{P}<0.001)$. The booking of appointments did not differ significantly between the women who received cancer education and those who received the cognitive behavioural intervention. It was difficult to assess the quality of this study as it was only published as an abstract and not further details were available.

\section{Attitudes to screening}

One trial ( $\mathrm{n}=3094)$ examined participants attitudes to Pap smear screening (Byles 1995). The following number of 384 responding women reported receiving the intervention: invitation letter 154 (72\%), invitation letter and behavioural prompts (e.g. prompt cards) designed to address aspects believed to be associated with poor screening rates 134 (78\%) letter, 100 (58\%) card, and 109 (64\%) pamphlet; control (not applicable). The following number of women responders said they had read the material sent: 1 . 147 (69\%); 2.128 (75\%) letter, 7 (4\%) card, 101 (59\%) pamphlet; control (not applicable). In terms of those women who received the invitation letter $118 / 151$ (78\%) of the women said that they were pleased to have the intervention personally addressed to them, only $1 / 151(1 \%)$ said they were displeased and the remainder were not sure. In comparison, of those women who received the invitation letter and behavioural prompts 89/132 (68\%) were pleased, $3 / 132(2 \%)$ were displeased and the remainder were unsure. 152/155 (98\%) of the women who received the invitation letter thought that the intervention should be sent to all women, $2 / 155$ (1\%) did not and the remainder were unsure. 124/ 130 (95\%) of women who received the invitation letter and behavioural prompts thought the intervention should be sent to all women, $1 / 130(1 \%)$ did not and the remainder were unsure.

\section{Costs of the interventions}

Five trials $(\mathrm{n}=7718$ participants in total) presented cost data (Binstock 1997, McDowell 1989, Oscarsson 2007, Stein 2005, Vogt 2003). The first trial used five different intervention groups (Binstock 1997). However only those groups that used an intervention aimed at women (and not healthcare providers) were included in this review: telephone invitation, invitation letter, and a control group. The total estimated costs (\$US) per intervention group were as follows: telephone invitation $\$ 4282$, invitation letter $\$ 1918$, memo to primary provider $\$ 8933$, medical record reminder $\$ 1090$ and control group (not stated). In terms of the uptake of screening tests invitation letters produced a greater increase compared with invitation letters or the control group.

The second trial used four different intervention groups, but again not all of the interventions were aimed solely at women, some were aimed at healthcare providers (McDowell 1989). The following groups were considered in this review: GP letter invitation, telephone invitation, and control (usual care). The estimated costs (\$US) per additional Pap smear performed as compared with usual care were: GP invitation letter $\$ 14.23$, telephone intervention $\$ 11.75$ (assuming a salary of $\$ 60$ ) or $\$ 5.88$ (assuming a salary of $\$ 30$ per hour).

The trial of Stein 2005 used four different intervention groups: No intervention (Control); telephone intervention; letter from Health Authority District Cervical Screening Commisioner on behalf of National Cervical Screening Programme and letter from a well known journalist and broadcaster. Cost effectiveness analysis 
performed. Average cost per attender was $£ 145.12$ for telephone call, $£ 14.29$ for letter from commissioner and $£ 37.14$ for letter from a celebrity.

The trial of Vogt 2003 had examined the costs of each smear gained in the intervention groups above the cost of a smear in the control (usual care) group. Cost effectiveness analysis showed that for each additional Pap smear, the letter/letter intervention cost $\$ 185$, the phone/phone intervention cost $\$ 305$ and the letter/ letter intervention cost $\$ 1117$ for each additional Pap smear. Oscarsson 2007 compared intensive recruitment using multiple methods with a control groups. The cost per smear was 66.87EURO and 16.63EURO respectively. Each additional smear obtained in the trial cost 151.36EURO.

\section{DISCUSSION}

\section{Summary of main results}

Overall, invitations and educational interventions appeared to be the most effective methods of increasing the absolute uptake of cervical screening. However, heterogeneity between the trials limited the statistical pooling of data. Evidence regarding the effectiveness of other interventions such as economic incentives, procedural interventions (i.e. revealing the gender of the smear taker and using a health promotion nurse), counselling and risk factor assessment was limited by the number of included trials and their moderate or high risk of bias. Furthermore, statistical pooling of the data were often limited by the presence of substantial heterogeneity between the trials.

\section{Invitations}

In general, invitation letters were effective at encouraging women to attend for a Pap smear. Cervical cancer screening programmes in the UK, Italy, Sweden and other countries already invite women to attend via a letter, with or without appointments, as part of their national call/recall system. However, the use of such systems in developing countries may be difficult to implement where issues of migration, literacy and access to remote areas may be of concern. There was also some limited evidence that telephone invitations increased uptake, but it was unclear whether this practice was more effective than invitation letters. Telephone invitations are not routinely used in organised screening programmes such as that in the UK and would be even more difficult to implement in developing countries where access to telephones may be an issue. It was also unclear as to whether sending invitation letters with appointments was any more effective than sending invitation letters alone. However, there was some evidence to suggest that invitation letters with fixed appointments were more effective than invitations with open appointments.
Current practice in the UK and a number of other countries involves sending invitation letters both from GPs and/or Health Authorities (NHS Information Centre 2010). The effectiveness of sending letters from different authority sources was evaluated in three trials (Bowman 1995; Segnan 1998; Stein 2005). All of these trials favoured GP/local authority letters over other sources. It is not possible to say definitively which approach was more effective, due to the limited evidence from good quality trials. No trial showed a cost-effectiveness benefit of any alternative invitation method over the standard care (usually a letter). Given the effectiveness of invitation letters in encouraging uptake and that no other intervention has been shown to be more cost effective, it remains appropriate to use existing invitation approaches. It must be recognised that for this approach to be effective, robust administrative procedures must be in place and a comprehensive, accurate, up-to-date register maintained.

\section{Education}

There was insufficient evidence in the form of statistically significant findings from good quality trials to support any particular educational intervention, but overall the consensus from the trials examining educational interventions was in favour of the intervention over the no intervention/usual care control. However, heterogeneity between the trials limited the statistical pooling of data. Amongst ethnic minority groups there appeared to be some limited evidence to support the use of lay members of the community in presenting culturally-tailored information, particularly when performed "face-to-face". This may be of relevance in developing countries where remote areas and literacy may be an issue. However, the findings may vary according to ethnic group and further research is required.

Educational materials are likely to be important in increasing informed uptake, providing they cover all aspects of the screening process. For example, the Department of Health in the UK has produced a leaflet emphasising the risks and benefits and this should be included with every invitation for screening (NHS CSP 2009). No trials have attempted to measure the effectiveness of interventions at increasing the informed uptake of Pap smears.

\section{Intensive recruitment attempts}

Although only examined in a single trial, intensive recruitment techniques, including telephone interviews, letters and other promotive efforts showed a promising increase in uptake. However, the cost per extra smear gained (151.36EURO) may limit the wider application of this approach.

\section{Overall completeness and applicability of evidence}


Future intervention trials should aim to minimise barriers to uptake amongst those who choose screening, based on a full understanding of the likely benefits, limitations and potential harm. Trials should include a measure of knowledge and whether the information provided is used in the decision making process. Just as an intervention to increase uptake may be ineffective, an intervention to increase informed uptake might also be ineffective. For example, it should not be assumed that giving a leaflet on the risks and benefits of screening will necessarily increase informed uptake. It may be that some interventions, which are effective for increasing uptake (such as appointments), are not effective at increasing informed uptake, and the opposite may also be true. Similarly interventions which are effective in developed countries may not be as effective in developing countries or may present problems in terms of their implementation. At present the evidence regarding the effectiveness of interventions is dominated by studies set in developed countries and there is a need for research which is likely to be more applicable to developing nations. Future trials should also consider ongoing changes in screening technology. As new screening tests become available their potential effects on participation levels in cervical screening programmes should be considered. At present randomised controlled trials are underway to assess the effectiveness of HPV testing and its likely role in the UK cervical screening programme. However, it has been suggested that the introduction of this test may adversely effect the screening uptake rates because of the connotation of sexual promiscuity attached to a positive HPV test/abnormal Pap smear.

Research into screening uptake including the uptake of Pap smears is still expanding with new studies being published each year. However, at present there is very little research relevant to developing countries and it is difficult to state with any degree of certainty how effective the interventions discussed in this review will be in such settings.

\section{Quality of the evidence}

The review and the findings of the review are very much dependent on the validity and quality of the 38 trials reported. The risk of bias of the individual trials included in the review was assessed independently by two review authors using pre-defined checklists. Although a number of the trials were of reasonable quality and only at moderate risk of bias, a number of remaining trials suffered from methodological problems and inadequate reporting. With regards to the latter attempts were made to contact authors to clarify various points, but replies were not received in a number of trials. Of note, several trials would have been eligible if proper randomisation procedures had been followed rather than using quasirandomisation techniques. A number of trials randomised women without first assessing their eligibility so leading to the exclusion of large numbers of women post-randomisation. Many trials also failed to use appropriate analyses such as intention to intervene analyses and the appropriate consideration of the effects of clus- tering in cluster randomised trials. By not adequately accounting for the potential effects of clustering data from a number of trials it was not available for inclusion in the summary of relative risk values.

Even though risk ratios were calculated in most of the RCTs included in this review, the pooling of data was restricted because of clinical heterogeneity. Of the meta-analyses that could be performed there was quite often substantial statistical heterogeneity present. The conclusions and implications for practice are primarily based on those interventions for which there was evidence from several RCTs, i.e. invitations and educational materials. However, issues of heterogeneity and study quality should be borne in mind when interpreting these findings. A number of trials looked at other interventions but these were often either limited in number, were of questionable validity or both. To increase informed uptake, future interventions should include information on the likely harms and risks, as well as the benefits of screening. These trials should include a measure of knowledge and whether this knowledge was used in the decision to undergo screening. Furthermore, more trials are needed which target ethnic minority groups and other groups where uptake is low.

\section{Potential biases in the review process}

The comprehensive search strategy used in the review is likely to have located most of the published trials and our thorough search of the grey literature meant that every attempt had been made to obtain data from unpublished trials. Decisions on the relevance of trials were made by two reviewers in a two stage sifting process. Titles and abstracts of the search results were initially searched, then full articles were sifted of potentially relevant papers identified from the initial sift. In cases of disagreement, a third reviewer was called to decide on disputed trials. We restricted the included studies to RCTs as they provide the strongest level of evidence available. We excluded quasi-randomised trials and other non-RCTs, hence we have attempted to reduce bias in the review process.

The greatest threat to the validity of the review is likely to be the possibility of publication bias i.e. studies that did not find the treatment to have been effective may not have been published. We were unable to assess this possibility for most outcomes as most comparisons of the interventions were restricted to either a meta analysis of only a low number of trials or single trial analyses. However, the analysis of invitations versus control did not suggest that publication bias was likely to be a problem. It is acknowledged that although abstracts, full articles and unpublished reports were found (through contacting experts in the field and searching the grey literature and reference lists), some may have been missed, but this risk of publication bias is likely to be minimal. 


\section{Agreements and disagreements with other studies or reviews}

A meta-analysis performed by Tseng 2001 showed that women who received a reminder letter to attend for cervical screening were significantly more likely to attend $(\mathrm{OR}=1.64,95 \% \mathrm{CI}: 1.49$ to 1.80) than those who received no intervention. This is in agreement with the findings of this Cochrane review. A meta-analysis by Yabroff 2003 agrees with the findings of this review that letter reminders and telephone reminders are effective at increasing cervical screening uptake. The findings of this review are also in agreement with the conclusion of Yabroff 2003 that media interventions do not lead to increased Papanicolou smear use and the finding that peer or lay health worker interventions may have a marginal, though not statistically significant benefit. However, this review is not in agreement with their conclusion that "telephone reminder was associated with the largest increase in Papanicolou smear use". Whilst this review shows telephone reminders to be effective, reminder letters with a fixed appointment appeared to be more so.

\section{AUTHORS' CONCLUSIONS}

\section{Implications for practice}

There was sufficient evidence from good quality RCTs to support the use of invitation letters in increasing the uptake of Pap smears. There was also some evidence to suggest that educational interventions may increase Pap smear uptake. Overall, educational materials appeared promising, but it is unclear without evidence from additional good quality RCTs which methods (i.e. printed, video/ slide or face to face presentations) are most effective. A number of other interventions including revealing the gender of the smear taker and using a health promotion nurse appeared to be promising approaches, but their effectiveness was only examined in a limited number of trials. Likewise interventions by lay health workers appear to be promising in improving uptake, although the number of trials in this area is limited. There was no evidence on which to base implications for practice regarding the informed uptake of cervical screening. Overall, these findings relate to screening in developed countries and their relevance to developing countries is unclear.

\section{Implications for research}

The following implications are likely to be relevant to screening in developed countries:

1. Invitations and educational materials appear to be effective at increasing uptake of cervical cancer screening. Further research into the relative effectiveness and cost effectiveness of these interventions would help to inform decision-making. In particular it is unclear which types of educational intervention are the most effective.

2. Further research is required to determine the effectiveness of promising interventions such as revealing in an invitation letter the gender of the smear taker, using a health promotion nurse, the use of lay outreach health workers and intensive attempts at recruitment.

3. When designing and reporting future trials researchers should pay particular attention to the following issues: the use of an adequate method of randomisation, the blinding of those assessing study outcome measures, adequate concealment of treatment allocation, adequate follow-up of all participants included in the initial randomisation process, selective reporting of outcomes, and the use of appropriate analyses, particularly in the case of cluster RCTs. Researchers should also try to ensure the enrolment of adequate numbers of eligible participants and interventions should be reported in sufficient detail.

4. A group of women who attend for smears that are particularly at risk are those with inadequate or abnormal smears. Further research should examine the effectiveness of various methods to ensure adequate attendance at follow up for abnormal smears.

5. A concentrated effort should be made to conduct good quality trials in developing countries. In these areas, there is usually no national screening programme, cervical screening is often non-existent and Pap smear or liquid based cytology are not practical. In such situations, other screening modalities such as visual inspection with acetic acid have been shown to acceptable, feasible and safe (Sankaranarayanan 2004) and should be considered.

\section{ACKNOWLEDGEMENTS}

This review was originally based on work carried out on behalf of the NHS R\&D Health Technology Assessment Programme. The following authors contributed to the original review: Carol Forbes, Ruth Jepson and Pierre Martin-Hirsch. Andy Clegg, Ruth Lewis, Amanda Sowden and Jos Kleijnen were acknowledged for contributing to the first version of the review. The authors also paid tribute to Lisa Mather for carrying out the literature searches, Hilary Bekker for helping to develop the inclusion criteria for informed uptake, and all of the authors who kindly supplied additional information.

In the updated review we thank Chris Williams for clinical and editorial advice, Jane Hayes for designing the search strategy and Gail Quinn and Clare Jess for their contribution to the editorial process. We also thank Heather Dickinson for many helpful suggestions and Yin Ling Woo and Maria Kyrgiou for helping with the sift. 


\section{R E F E R E N C E S}

\section{References to studies included in this review}

Adab 2003 \{published data only\}

Adab P, Marshall T, Rouse A, Randhawa B, Sangha H, Bhangoo, N. Randomised controlled trial of the effect of evidence based information on women's willingness to participate in cervical cancer screening. Journal of Epidemiology and Community Health 2003;57(8):589-93.

Allen 2001 \{published data only\}

Allen JD, Stoddard AM, Mays J, Sorensen G. Promoting breast and cervical cancer screening at the workplace: results from the Woman to Woman Study. American Journal of Public Health 2001;91(4):584-90.

Binstock 1997 \{published and unpublished data\}

* Binstock MA, Geiger AM, Hackett JR, Yao JF. Pap smear outreach: a randomized controlled trial in an HMO. American Journal of Preventive Medicine 1997;13(6):425-6.

Bowman 1995 \{published data only (unpublished sought butnot used)\} * Bowman J, Sanson-Fisher R, Boyle C, Pope S, Redman $S$. A randomised controlled trial of strategies to prompt attendance for a Pap smear. Journal of Medical Screening 1995;2(4):211-8

Buehler 1997 \{published data only (unpublished sought but not used)\} * Buehler SK, Parsons WL. Effectiveness of a call/recall system in improving compliance with cervical cancer screening: a randomized controlled trial. Canadian Medical Association Journal 1997;157(5):521-6.

Burack 1998 \{published and unpublished data\}

* Burack RC, Gimotty PA, George J, McBride S, Moncrease A, Simon MS, et al.How reminders given to patients and physicians affected pap smear use in a health maintenance organization: results of a randomized controlled trial. Cancer 1998;82(12):2391-400.

Burack 2003 \{published data only\}

Burack RC, Gimotty PA, Simon M, Moncrease A, Dews P. The effect of adding Pap smear information to a mammography reminder system in an HMO: results of randomized controlled trial. Preventive Medicine 2003;36 (5):547-54.

Byles 1994 \{published and unpublished data\}

* Byles JE, Sanson-Fisher RW, Redman S, Dickinson JA,

Halpin S. Effectiveness of three community based strategies to promote screening for cervical cancer. Journal of Medical Screening 1994;1(3):150-8.

Byles 1995 \{published and unpublished data\}

* Byles JE, Redman S, Sanson-Fisher RW, Boyle C. A trial of two direct-mail strategies to encourage women to have Pap smears. Health Promotion International 1995;10:5-16.
Byles 1996 \{published and unpublished data\}

* Byles JE, Sanson-Fisher RW. Mass mailing campaigns to promote screening for cervical cancer: do they work, and do they continue to work?. Australian \& New Zealand Journal of Public Health 1996;20(3):254-60.

Clementz 1990 \{published data only (unpublished sought but not used)\}

* Clementz GL, Aldag JC, Gladfelter TT, Barclay AM, Brooks HF. A randomized study of cancer screening in a family practice setting using a recall model. Journal of Family Practice 1990;30(5):537-41.

Del Mar 1998 \{published and unpublished data\} * Del Mar C, Glasziou P, Adkins P, Hua T, Brown M. Do personalised letters in Vietnamese increase cervical cancer screening among Vietnamese women? A randomised controlled trial. Australian and New Zealand journal of Public Health 1998;22(7):824-5.

Eaker 2004 \{published data only\} Eaker S, Adami HO, Granath F, Wilander E, Sparen P. A large population-based randomized controlled trial to increase attendance at screening for cervical cancer. Cancer Epidemiology, Biomarkers \& Prevention 2004;13(3):346-54.

Greene 1999 \{published data only\}

Greene PG, Smith DE, Kratt PP, Mayo MS, Harrison R, Partridge E. Promoting cervical cancer screening in a rural minority primary care setting. Annals of Behavioral Medicine 1999;21:SO57.

Hunt 1998 \{published and unpublished data\} Hunt JM, Lawton Gless G, Straton JAY. Pap smear screening at an urban aboriginal health service: report of a practice audit and an evaluation of recruitment strategies. Australian and New Zealand Journal of Public Health 1998; 22(6):720-25.

Kreuter 1996 \{published data only (unpublished sought but not used)\}

* Kreuter M, Strecher V. Do tailored behavior change messages enhance the effectiveness of health risk appraisal? Results from a randomized trial. Health Education Research 1996;11(1):97-105.

Lancaster 1992 \{published data only (unpublished sought but not used)\}

* Lancaster G, Elton P. Does the offer of cervical screening with breast screening encourage older women to have a cervical smear test?. Journal of Epidemiology \& Community Health 1992;46(5):523-7.

McAvoy 1991 \{published data only (unpublished sought but not used)\} * McAvoy BR, Raza R. Can health education increase uptake of cervical smear testing among Asian women?. BMJ 1991;302(6780):833-6. 
McDowell 1989 \{published and unpublished data\}

* McDowell I, Newell C, Rosser W. Computerized reminders to encourage cervical screening in family practice. Journal of Family Practice 1989b;28(4):420-4.

Mock 2007 \{published data only\}

Mock J, McPhee SJ, Nguyen T, Wong C, Doan H, Lai KQ, et al.Effective lay health worker outreach and media-based education for promoting cervical cancer screening among Vietnamese American women. American Journal of Public Health 2007;97(9):1693-700.

Morrell 2005 \{published data only\} Morrell S, Taylor R, Zeckendorf S, Niciak A, Wain G, Ross J. How much does a reminder letter increase cervical screening among under-screened women in NSW? Australian \& New Zealand Journal of Public Health 2005;29 (1):78-84.

Navarro 1995 \{published data only (unpublished sought but not used)\} * Navarro AM, Senn KL, Kaplan RM, McNicholas L, Campo MC, Roppe B. Por La Vida intervention model for cancer prevention in Latinas. Monographs National Cancer Institute 1995;18:137-45.

Ornstein 1991 \{published and unpublished data\} * Ornstein SM, Garr DR, Jenkins RG, Rust PF, Arnon A. Computer-generated physician and patient reminders. Tools to improve population adherence to selected preventive services. Journal of Family Practice 1991;32(1): $82-90$.

Oscarsson 2007 \{published data only\} Oscarsson MG, Benzein EG, Wijma BE, Carlsson PG. Promotion of cervical screening among nonattendees: a partial cost-effectiveness analysis. European Journal of Cancer Prevention 2007;16(6):559-63.

Pierce 1989 \{published and unpublished data\}

* Pierce M, Lundy S, Palanisamy A, Winning S, King J. Prospective randomised controlled trial of methods of call and recall for cervical cytology screening. BMJ 1989;299 (6692):160-2.

Pritchard 1995 \{published and unpublished data\}

* Pritchard DA, Straton JA, Hyndman J. Cervical screening in general practice. Australian Journal of Public Health 1995; 19(2):167-72.

Rimer 1999 \{published data only (unpublished sought but not used)\}

* Rimer B. The impact of tailored interventions on a community health center population. Patient Education and Counselling 1999;37:125-40.

Risi 2004 \{published data only\}

Risi L, Bindman JP, Campbell OM, Imrie J, Everett K, Bradley J, et al.Media interventions to increase cervical screening uptake in South Africa: an evaluation study of effectiveness. Health Education Research 2004;19(4): 457-68.

Rivers 2005 \{published data only\}

Rivers SE, Salovey P, Pizarro DA, Pizarro J, Schneider TR.

Message framing and pap test utilization among women attending a community health clinic. Journal of Health Psychology 2005;10(1):65-77.
Robson 1989 \{published and unpublished data\}

* Robson J, Boomla K, Fitzpatrick S, Jewell AJ, Taylor $\mathrm{J}$, Self $\mathrm{J}$, et al.Using nurses for preventive activities with computer assisted follow up: a randomised controlled trial. BMJ 1989;298(6671):433-6.

Segnan 1998 \{published and unpublished data\}

* Segnan N, Senore C, Giordano L, Ponti A, Ronco G. Promoting participation in a population screening program for breast and cervical cancer: a randomized trial of different invitation strategies. Tumori 1998;84(3):348-53.

Somkin 1997 \{published and unpublished data\}

* Somkin PA, Hiatt RA, Hurley LB, Gruskin E, Ackerson

L, Larson P. The effect of patient and provider reminders on mammography and Papanicolaou smear screening in a large Health Maintenance Organization.. Archives of Internal Medicine 1997;157:1658-64.

Stein 2005 \{published data only\}

Stein K, Lewendon G, Jenkins R, Davis C. Improving uptake of cervical cancer screening in women with prolonged history of non-attendance for screening: a randomized trial of enhanced invitation methods. Journal of Medical Screening 2005;12(4):185-9.

Sung 1997 \{published data only (unpublished sought but not used)\} * Sung JFC, Blumenthal DS, Coates RJ, Williams JF, AlemaMensah E, Liff JM. Effect of a cancer screening intervention conducted by lay health workers among innercity women. American Journal of Preventive Medicine 1997; 13(1):51-57.

Taylor 2002 \{published data only\}

Taylor VM, Hislop TG, Jackson JC, Tu SP, Yasui Y, Schwartz SM, et al.A randomized controlled trial of interventions to promote cervical cancer screening among Chinese women in North America. Journal of the National Cancer Institute 2002;94(9):970-7.

Vogt 2003 \{published data only\}

Vogt TM, Glass A, Glasgow RE, La Chance PA, Lichtenstein E. The safety net: a cost-effective approach to improving breast and cervical cancer screening. Journal of Women's Health 2003;12(8):789-98.

Ward 1991 \{published and unpublished data\} * Ward JE, Boyle K, Redman S, Sanson-Fisher RW. Increasing women's compliance with opportunistic cervical cancer screening: a randomized trial. American Journal of Preventive Medicine 1991;7(5):285-91.

Wilson 1987 \{published and unpublished data\}

* Wilson A, Leeming A. Cervical cytology screening: a comparison of two call systems. BMJ 1987;295:181-82.

\section{References to studies excluded from this review}

Al Saifafi 2009 \{published data only\}

Al Sairafi, Mohamed FA. Knowledge, attitudes, and practice related to cervical cancer screening among Kuwaiti women. Medical Principles and Practice 2009;18(1):35-42.

Baele 1998 \{published data only\}

Baele J. The influence of a home-visit on the participation of Moroccan and Spanish women in cervical cancer screening: 
an intervention study [De invloed van een huisbezoek op de participatie van Marokkaanse en Spaanse vrouwen aan een bevolkigsonderzoek naar baarmoederhalskanker in Vlaams-Brabant. Een interventiestudie]. Tijdschrift voor Sociale Gezondheidszorg 1998;76:374-80.

\section{Boissel 1995 \{published data only\}}

Boissel JP, Collet JP, Alborini A, Cordel JC, Filsnoel J, Gillet J, et al.Education program for general practitioners on breast and cervical cancer screening: a randomized trial. PRE.SA.GF Collaborative Group. Revue d'épidémiologie et de santé publique 1995;43(6):541-7.

Bonevski 1999 \{published data only\}

Bonevski B, Sanson Fisher RW, Campbell E, Carruthers A, Reid AL, et al.Randomized controlled trial of a computer strategy to increase general practitioner preventive care. Preventive Medicine 1999;29(6 Pt 1):478-86.

Brewster 2002 \{published data only\} Brewster WR, Anton Culver H, Ziogas A, Largent J, Howe $S$, et al.Recruitment strategies for cervical cancer prevention study. Gynecologic Oncology 2002;85(2):250-4.

Campbell 1997 \{published data only\}

* Campbell E, Peterkin D, Abbott R, Rogers J. Encouraging underscreened women to have cervical cancer screening: the effectiveness of a computer strategy.. Preventive Medicine 1997;26:801-807.

\section{Cecchini 1989 \{published data only\}}

Cecchini S, Grazzini G, Bartoli D, Falvo I, Ciatto S. An attempt to increase compliance to cervical cancer screening through general practitioners. Tumori 1989;75(6):615-18.

Chumworathayi 2007 \{published data only\} Chumworathayi B, Yuenyao P, Luanratanakorn S, Pattamadilok J, Chalapati W, Na-Nhongkai C. Can an appointment-letter intervention increase pap smear screening in Samliem, Khon Kaen, Thailand?. Asian Pacific Journal of Cancer Prevention: Apjcp 2007;8(3):353-6.

Corkrey 2005 \{published data only\}

Corkrey R, Parkinson L, Bates L. Pressing the key pad: trial of a novel approach to health promotion advice. Preventive Medicine 2005;41(2):657-66.

Del Mar 1995 \{published data only\}

* Del Mar CB, Wright RG. Notifying women of the results of their cervical smear tests by mail: does it result in a decreased loss to follow-up of abnormal smears.. Australian Journal of Public Health 1995;19(2):211-13.

Dignan 1996 \{published data only (unpublished sought but not used)\} Dignan M, Michielutte R, Blinson K, Wells HB, Case LD, Sharp $\mathrm{P}$, et al.Effectiveness of health education to increase screening for cervical cancer among eastern-band Cherokee Indian women in North Carolina. Journal of the National Cancer Institute 1996;88(22):1670-6.

Dignan 1998 \{published data only (unpublished sought but not used)\} Dignan MB, Michielutte R, Wells BH, Sharp P, Blinson K, Case LD, et al.Health education to increase screening for cervical cancer among Lumbee Indian women in North Carolina. Health Education Research 1998;13(4):545-56.
Engelstad 2005 \{published data only\}

Engelstad LP, Stewart S, Otero-Sabogal R, Leung MS, Davis PI, Pasick RJ. The effectiveness of a community outreach intervention to improve follow-up among underserved women at highest risk for cervical cancer. Preventive Medicine 2005;41(3-4):741-8.

\section{German 1995 \{published and unpublished data\}}

* German PS, Burton LC, Shapiro S, Steinwachs DM, Tsuji I, Paglia MJ, et al.Extended coverage for preventive services for the elderly: response and results in a demonstration population. American Journal Public Health 1995;85(3): 379-86.

Gotay 2000 \{published data only\} Gotay CC, Banner RO, Matsunaga DS, Hedlund N, Enos R, Issell BF, DeCambra H. Impact of a culturally appropriate intervention on breast and cervical screening among native Hawaiian women. Preventive Medicine 2000; 31(5):529-37.

Hancock 2001 \{published data only\}

Hancock L, Sanson Fisher R, Perkins J, Corkrey R, Burton $\mathrm{R}$, Reid S. Effect of a community action intervention on cervical cancer screening rates in rural Australian towns: the CART project. Preventive Medicine 2001;32(2):109-17.

Hicks 1997 \{published and unpublished data\} Hicks C, Robinson K. Cervical screening: the impact of the gender of the smear-taker on service uptake. Health Services Management Research 1997;10 (3):187-9.

Hillman 1998 \{published data only\}

Hillman AL, Ripley K, Goldfarb N, Nuamah I, Weiner J, Lusk E. Physician financial incentives and feedback: failure to increase cancer screening in Medicaid managed care. American Journal of Public Health 1998;88(11):1699-701.

Holloway 2003 \{published data only\} Holloway RM, Wilkinson C, Peters TJ, Russell I, Cohen D, Hale J, et al.Cluster-randomised trial of risk communication to enhance informed uptake of cervical screening. British Journal of General Practice 2003;53(493):620-5.

Hou 2002 \{published data only\}

Hou SI, Fernandez ME, Baumler E, Parcel GS. Effectiveness of an intervention to increase Pap test screening among Chinese women in Taiwan. Journal of Community Health 2002;27(4):277-90.

Hou 2005 \{published data only\}

Hou SI. Stage of adoption and impact of direct-mail communications with and without phone intervention on Chinese women's cervical smear screening behavior. Preventive Medicine 2005;41(3-4):749-56.

Jenkins 1999 \{published data only\} Jenkins CN, McPhee SJ, Bird JA, Pham GQ, Nguyen $\mathrm{BH}$, Nguyen T, et al.Effect of a media-led education campaign on breast and cervical cancer screening among Vietnamese-American women. Preventive Medicine 1999; 28(4):395-406.

Karwalajtys 2007 \{published data only\} Karwalajtys T, Kaczorowski J, Lohfeld L, Laryea S, Anderson K, Roder S, Sebaldt RJ. Acceptability of reminder 
letters for Papanicolaou tests: a survey of women from 23 Family Health Networks in Ontario. Journal of Obstetrics \& Gynaecology Canada: JOGC 2007;29(10):829-34.

Katz 2007 \{published data only\} Katz ML, Tatum CM, Degraffinreid CR, Dickinson S, Paskett ED. Do cervical cancer screening rates increase in association with an intervention designed to increase mammography usage?. Journal of Women's Health 2007;16 (1):24-35.

Lam 2003 \{published data only\}

Lam TK, McPhee SJ, Mock J, Wong C, Doan HT, Nguyen $\mathrm{T}$, et al.Encouraging Vietnamese-American women to obtain Pap tests through lay health worker outreach and media education. Journal of General Internal Medicine 2003; 18(7):516-24.

Lantz 1995 \{published and unpublished data\} Lantz P, Stencil D, Lippert M, Beversdorf S, Jaros L, Remington P. Breast and cervical cancer screening in a lowincome managed care sample: the efficacy of physician letters and phone calls.. American Journal of Public Health 1995;85(6):834-36.

Lantz 1996 \{published data only\} Lantz PM, Stencil D, Lippert MT, Jaros L, Eaker ED. Implementation issues and costs associated with a proven strategy for increasing breast and cervical cancer screening among low-income women. Journal of Public Health Management and Practice: JPHMP 1996;2(3):54-9.

Lauver 1990 \{published data only\}

Lauver D, Rubin M. Message framing, dispositional optimism, and follow-up for abnormal Papanicolaou tests. Research in Nursing \& Health 1990;13(3):199-207.

\section{Levine 2003 \{published data only\}} Levine RS, Husaini BA, Emerson JS, Hull PC, Briggs NC, Moriarty CJ, et al.Using a nursing protocol to assure equitable delivery of cancer-related prevention services. Cellular \& Molecular Biology 2003;49(8):1229-32.

\section{Litzelman 1993 \{published data only\}} Litzelman DK, Dittus RS, Miller ME, Tierney WM. Requiring physicians to respond to computerized reminders improves their compliance with preventive care protocols. Journal of general internal medicine : official journal of the Society for Research and Education in Primary Care Internal Medicine 1993;8(6):311-7.

Lynch 2004 \{published data only\} Lynch FL, Whitlock EP, Valanis BG, Smith SK. Costeffectiveness of a tailored intervention to increase screening in HMO women overdue for Pap test and mammography services. Preventive Medicine 2004;38(4):403-11.

Manfredi 1998 \{published data only\}

Manfredi C, Czaja R, Freels S, Trubitt M, Warnecke R, Lacey L. Prescribe for health. Improving cancer screening in physician practices serving low-income and minority populations. Archives of Family Medicine 1998;7(4):329-37.

Marcus 1992 \{published data only (unpublished sought but not used)\} Marcus AC, Crane LA, Kaplan CP, Reading AE, Savage E, Gunning J, et al.Improving adherence to screening follow- up among women with abnormal Pap smears: results from a large clinic-based trial of three intervention strategies. Medical Care 1992;30(3):216-30.

Marcus 1998 \{published data only\}

Marcus AC, Kaplan CP, Crane LA, Berek JS, Bernstein G, Gunning JE, et al.Reducing loss-to-follow-up among women with abnormal Pap smears. Results from a randomized trial testing an intensive follow-up protocol and economic incentives. Medical Care 1998;36(3):397-410.

Margolis 1998 \{published data only (unpublished sought but not used)\}

Margolis KL, Lurie N, McGovern PG, Tyrrell M, Slater

JS. Increasing breast and cervical cancer screening in lowincome women. Journal of General Internal Medicine 1998; 13(8):515-21.

Maxwell 2003 \{published data only\}

Maxwell AE, Bastani R, Vida P, Warda US. Results of a randomized trial to increase breast and cervical cancer screening among Filipino American women. Preventive Medicine 2003;37(2):102-9.

Mayer 1992 \{published data only\}

Mayer JA, Slymen DJ, Drew JA, Wright BL, Elder JP, Williams SJ. Breast and cervical cancer screening in older women: the San Diego Medicare Preventive Health Project. Preventive Medicine 1992;21(4):395-404.

Miller 1999 \{published data only\}

Miller SM, Buzaglo JS, Simms SL, Green V, Bales C, Mangan CE, et al.Monitoring styles in women at risk for cervical cancer: implications for the framing of healthrelevant messages. Annals of behavioral medicine : a publication of the Society of Behavioral Medicine 1999;21(1): 27-34.

Miller 2007 \{published data only\}

Miller E, Lasser KE, Becker AE. Breast and cervical cancer screening for women with mental illness: patient and provider perspectives on improving linkages between primary care and mental health. Archives of Women's Mental Health 2007;10(5):189-97.

Mitchell 1991 \{published data only\}

* Mitchell H, Hirst S, Cockburn J, Reading DJ, Staples MP, Medley G. Cervical cancer screening: a comparison of recruitment strategies among older women. The Medical Journal of Australia 1991;155(2):79-82.

Mitchell 1997 \{published data only\} Mitchell H, Hirst S, Mitchell JA, Staples M, Torcello N. Effect of ethnic media on cervical cancer screening rates. Australian and New Zealand Journal of Public Health 1997; 21(3):265-7.

Newell 2002 \{published data only\}

Newell SA, Sanson Fisher RW, Girgis A, Davey HM. Can personal health record booklets improve cancer screening behaviors?. American Journal of Preventive Medicine 2002; 22(1):15-22.

Nguyen 2000 \{published data only\}

Nguyen BH, Nguyen KP, McPhee SJ, Nguyen AT, Tran DQ, Jenkins CN. Promoting cancer prevention activities 
among Vietnamese physicians in California. Journal of Cancer Education 2000;15(2):82-5.

Park 2005 \{published data only\}

Park S, Chang S, Chung C. Effects of a cognition-emotion focused program to increase public participation in Papanicolaou smear screening. Public Health Nursing 2005; 22(4):289-98.

\section{Paskett 1990 \{published and unpublished data\}}

Paskett ED, White E, Carter WB, Chu J. Improving followup after an abnormal Pap smear: a randomized controlled trial. Preventive Medicine 1990;19(6):630-41.

Paskett 1995 \{published data only\} Paskett ED, Phillips KC, Miller ME. Improving compliance among women with abnormal Papanicolaou smears. Obstetrics and Gynecology 1995;86(3):353-9.

Paskett 1999 \{published data only\}

Paskett ED, Tatum CM, D’Agostino RJr, Rushing J, Velez $\mathrm{R}$, Michielutte $\mathrm{R}$, et al.Community-based interventions to improve breast and cervical cancer screening: results of the Forsyth County Cancer Screening (FoCaS) Project. Cancer Epidemiology, Biomarkers \& Prevention 1999;8(5):453.

Paul 2003 \{published data only\}

Paul CL, Redman S, Sanson-Fisher RW. Print material content and design: is it relevant to effectiveness?. Health Education Research 2003;18(2):181-90.

Perkins 2007 \{published data only\}

Perkins RB, Langrish S, Stern LJ, Simon CJ. A communitybased education program about cervical cancer improves knowledge and screening behavior in Honduran women. Pan American Journal of Public Health 2007;22(3):187-93.

Peters 1999 \{published data only (unpublished sought but not used)\} Peters T, Somerset M, Baxter K, Wilkinson C. Anxiety among women with mild dyskaryosis: a randomized trial of an educational intervention. British Journal of General Practice 1999;49:348-52.

Philips 2006 \{published data only\}

Philips Z, Whynes DK, Avis M. Testing the construct validity of willingness to pay valuations using objective information about risk and health benefit. Health Economics 2006;15(2):195-204.

Powers 1992 \{published data only\}

Powers RL, Shumway JM. Written patient reminders improve cancer screening practices. Clinical Research 1992; 40(2):A610

Roetzheim 2004 \{published data only\}

Roetzheim RG, Christman LK, Jacobsen PB, Cantor AB, Schroeder J, Abdulla R, et al.A randomized controlled trial to increase cancer screening among attendees of community health centers. Annals of Family Medicine 2004;2(4): 294-300.

Roetzheim 2005 \{published data only\} Roetzheim RG, Christman LK, Jacobsen PB, Schroeder J, Abdulla R, Hunter S. Long-term results from a randomized controlled trial to increase cancer screening among attendees of community health centers. Annals of Family Medicine 2005;3(2):109-14

\section{Ruffin 2004 \{published data only\}}

Ruffin IVMT, Gorenflo DW, Murff HJ. Increasing cancer screening rates in primary care: No easy solutions. Journal of Clinical Outcomes Management 2004;11(12):754-55.

Sankaranarayanan 2003 \{published data only\}

Sankaranarayanan R, Rajkumar R, Arrossi S, Theresa R, Esmy PO, Mahe C, et al.Determinants of participation of women in a cervical cancer visual screening trial in rural south India. Cancer Detection \& Prevention 2003;27(6): 457-65.

Shelley 1991 \{published data only\}

Shelley JM, Irwig LM, Simpson JM, Macaskill P. Evaluation of a mass-media-led campaign to increase Pap smear screening. Health Education Research 1991;6(3):267-277.

Stewart 1994 \{published data only\}

Stewart DE, Buchegger PM, Lickrish GM, Sierra S. The effect of educational brochures on follow-up compliance in women with abnormal Papanicolaou smears. Obstetrics and Gynecology 1994;83(4):583-5.

Takacs 2004 \{published data only\}

Takacs P, Chakhtoura N, De Santis T. Video colposcopy improves adherence to follow-up compared to regular colposcopy: a randomized trial. Archives of Gynecology \& Obstetrics 2004;270(3):182-4.

Tomlinson 2004 \{published data only\}

Tomlinson A, Kyrgiou M, Paraskevaidis E, Kitchener, H, Martin-Hirsch P. Does improving communication and information for women increase attendance at colposcopy in an inner city clinic? A randomised controlled trial. European Journal of Gynaecological Oncology 2004;25(4): 445-8.

Torres-Mejia 2000 \{published data only\}

Torres Mejía G, Salmerón Castro J, Téllez Rojo MM, Lazcano Ponce EC, Juárez Márquez SA, Torres Torija I, et al.Call and recall for cervical cancer screening in a developing country: a randomised field trial. International journal of cancer. Journal international du cancer 2000;87 (6):869-73.

Valanis 2003 \{published data only\}

* Valanis B, Whitlock EE, Mullooly J, Vogt T, Smith S, Chen $\mathrm{C}$, et al.Screening rarely screened women: time-toservice and 24-month outcomes of tailored interventions.. Preventative Medicine 2003;37(5):42-50.

Ward 1999 \{published and unpublished data\}

Ward JE, Proude EM. Evaluation of doctors' reminders in emergency departments to encourage cervical screening. Australian and New Zealand Journal of Public Health 1999; 23(1):95-8.

Yancey 1995 \{published data only (unpublished sought but not used)\} Yancey AK, Tanjasiri SP, Klein M, Tunder J. Increased cancer screening behavior in women of color by culturally sensitive video exposure. Preventive Medicine 1995;24(2): $142-8$. 


\section{Additional references}

\section{Arditi 2010}

Arditi C, Walther MR, Burnand B, Wyatt J. Computergenerated paper reminders: effects on professional practice and health care outcomes. Cochrane Database of Systematic Reviews 2010, Issue 3. [DOI: 10.1002/ 14651858.CD001175]

\section{Brinton 1986}

Brinton LA, Schairer C, Haenszel W. Cigarette smoking and invasive cervical cancer. JAMA : the journal of the American Medical Association 1986;255:3265.

\section{Brinton 1994}

Brinton LA. Ways that women may possibly reduce their risk of breast cancer. Journal of National Cancer Institute 1994;86:371-2.

\section{Deeks 2001}

Deeks JJ, Altman DG, Bradburn MJ. Statistical methods for examining heterogeneity and combining results from several studies in meta-analysis. In: Egger M, Davey Smith $G$, Altman DG (eds). Systematic Reviews in Health Care: Meta-Analysis in Context (2nd edition). . London: BMJ Publication Group, 2001.

\section{DerSimonian 1986}

DerSimonian R, Laird N. Meta-analysis in clinical trials. Control Clin Trials 1986;7:177-188.

\section{EUROCARE 2003}

Sant M, Aareleid T, Berrino F, Bielska Lasota M, Carli PM, Faivre J, Grosclaude P, Hédelin G, Matsuda T, Møller H, Möller T, Verdecchia A, Capocaccia R, Gatta G, Micheli A, Santaquilani M, Roazzi P, Lisi D, and the EUROCARE Working Group. EUROCARE-3: survival of cancer patients diagnosed 1990-94 - results and commentary. Annals of Oncology 2003;14 (Supplement 5):v61-v118.

\section{Freemantle 1997}

Freemantle N, Harvey EL, Wolf F, Grimshaw JM, Grilli R, Bero LA. Printed educational materials: effects on professional practice and health care outcomes. Cochrane Database of Systematic Reviews 1997, Issue 3 Art No.: CD000172. DOI: 10.1002/14651858.CD000172. [DOI: 10.1002/14651858.CD000172]

\section{GLOBOCAN 2008}

Ferlay J, Shin HR, Bray F, Forman D, Mathers C, Parkin DM. GLOBOCAN 2008, Cancer Incidence and Mortality Worldwide: IARC CancerBase No. 10 [Internet]. Available from: http://globocan.iarc.fr 2010.

\section{Gordon 1998}

Gordon RB, Grimshaw JM, Eccles M, Rowe RE, Wyatt JC. On-screen computer reminders: effects on professional practice and health care outcomes [protocol]. Cochrane Database of Systematic Reviews 1998, Issue 2. [DOI: 10.1002/14651858.CD001096]

Grilli 2002

Grilli R, Freemantle N, Minozzi S, Domenighetti G, Finer D. Mass media interventions: effects on health services utilisation. Cochrane Database of Systematic Reviews
2002, Issue 1. [DOI: 10.1002/14651858.CD000389; : PUBMED: ]

\section{Hade 2010}

Hade EM, Murray DM, Pennell ML, Rhoda D, Paskett ED, Champion VL, Crabtree BF, Dietrich A, Dignan MB, Farmer M, Fenton J, Flocke S, Hiatt RA, Hudson SV, Mitchell M, Monahan P, Shariff-Marco S, Slone SL, Stange K, Stewart SL, Ohman Strickland PA. Intraclass Correlation Estimates for Cancer Screening Outcomes: Estimates and Applications in the Design of Group-Randomized Cancer Screening Studies. Journal of the National Cancer Institute Monograph 2010;40:97-103.

\section{Higgins 2003}

Higgins JPT, Thompson SG, Deeks JJ, Altman DG. Measuring inconsistency in meta-analyses. BMJ 2003;327: 557-560.

\section{Hulscher 2006}

Hulscher MEJL, Wensing M, Van der Weijden T, Grol R, Van Weel C. Interventions to implement prevention in primary care. Cochrane Database of Systematic Reviews 2006, Issue 1. [DOI: 10.1002/14651858.CD000362]

\section{IARC 1986}

IARC working group. Screening for squamous cervical cancer: Duration of low risk after negative results of cervical cytology and its implication for screening policies. IARC working group on evaluation of cervical cancer screening programmes. British Medical Journal 1986;293(6548): 659-664.

Ilter 2010

Ilter E, Celik A, Halioglu B, Unlugedik E, Midi A, Gundux T, Ozekici U. Women's knowledge of Pap smear test and human papillomavirus: acceptance of HPV vaccination to themselves and their daughters in an Islamic society. International Journal of Gynecological Cancer 2010;20(6): 1058-1062.

\section{Jamtvedt 2006}

Jamtvedt G, Young JM, Kristoffersen DT, O’Brien MA, Oxman AD. Audit and feedback: effects on professional practice and health care outcomes. Cochrane Database of Systematic Reviews 2006, Issue 1. [DOI: 10.1002/ 14651858.CD000259.pub2]

Jemal 2008

Jemal A, Siegel R, Ward E, Hao Y, Xu J, Murray T, Thun MJ. Cancer Statistics. CA Cancer J Clin 2008;58:71-96.

\section{Jepson 2000}

Jepson R, Clegg A, Forbes C, Lewis R, Sowden A, Kliejnen J. The determinants of screening uptake and interventions for increasing uptake: a systematic review. Health Technology Assessment 2000; Vol. 4, issue 14

\section{La Vecchia 1986}

La Vecchia C, Franceschi S, Decarli A. Sexual factors, venereal diseases and the risk of intraepithelial and invasive cervical neoplasia. Cancer 1986;58:935. 


\section{Luke 1996}

Luke K. Cervical cancer screening: meeting the needs of minority ethnic women. British Journal of Cancer 1996;74 (Suppl. XXIX):S47-50.

\section{Miller 1994}

Miller BA, Kolonel LN, Bernstein L. Raciallethnic patterns of cancer in the United States 1988-1992. Bethesda, MD: National Cancer Institute; NIH Publications, no. 96-4101, 1994.

\section{Moser 2009}

Moser K, Patnick J, Beral V. Inequalities in reported use of breast and cervical screening in Great Britain: analysis of cross sectional survey data. BMJ 2009;338:b2025.

Moss 2004

Moss SM, Gray A, Marteau T, Legood R, Henstock E, Maissi E. Evaluation of HPB/LBC cervical Screening Pilot Studies. Report to the Department of Health. http //www.cancerscreening.nhs.uk/cervical/evaluation-hpv2006feb.pdf 2004.

\section{NHS CSP 2009}

National Health Service Cervical Screening Programmes. Cervical Screening: The Facts. NHS Cervical Screening Programme http://www.cancerscreening.nhs.uk/cervical/ publications/nhscsp-the-facts.pdf 2009.

\section{NHS Information Centre 2010}

The NHS Information Centre, Public Health Indicators and Population Statistics. Cervical Screening Programme England 2009-10. http://www.ic.nhs.uk/ webfiles/publications $/ 008 \cdot$ Screening/cervscreen0910/ Final 'Report'v2'20Oct2010.pdf 2010.

\section{NICE 2003}

National Institute for Clinical Excellence. Technology Appraisal Guidance 69. Guidance on the use of liquid-based cytology for cervical screening. http://www.nice.org.uk/ nicemedia/pdf/TA69 'LBC' review' FullGuidance.pdf 2003.

\section{Nottingham 1998}

Nottingham J. Informed consent: Screening programmes need consent forms [Letter]. BMJ 1998;317(7163): 948-949.

\section{O'Brien 1997}

O'Brien MA, Oxman AD, Davis DA, Haynes RB, Freemantle N, Harvey EL. Educational outreach visits: effects on professional practice and health care outcomes. Cochrane Database of Systematic Reviews 2001, Issue 4. [DOI: 10.1002/14651858.CD000409]

\section{ONS 2010}

Walters S, Nur U, Rachet B, Gordon E, Jakomis N, Edgar G, Coleman MP. Cancer survival in England:one-year and five-year survival for 21 common cancers, by sex and age. Patients diagnosed 2003-2007 and followed up to 2008. Statistical Bulletin, Office of National Statistics 2010.

\section{Peto 2004}

Peto J, Gilham C, Fletcher O, Matthews FE. The cervical cancer epidemic that screening has prevented in the UK. The Lancet 2004;364(9430):249-56 .

\section{Ries 1999}

Ries LAG, Kosary CL, Hankey BE, editors. SEER cancer statistics review, 1973-1996. Bethesda, MD: US Department of Health and Human Services, National Cancer Institute, 1999.

\section{Romero 2004}

Romero A, Green ME, Pantoja T, Wyatt J, Grimshaw JM, Altman D. Manual paper reminders: effects on professional practice and health care outcomes [protocol]. Cochrane Database of Systematic Reviews 2004, Issue 2. [DOI: 10.1002/14651858.CD001174]

\section{Sankaranarayanan 2004}

Sankaranarayanan R, Rajkumar R, Theresa R, Esmy PO, Mahe C, Bagyalakshmi KR, Thara S, Frappart L, Lucas E, Muwonge R, Shanthakumari S, Jeevan D, Subbarao TM, Parkin DM, Cherian J. Initial results from a randomized trial of cervical visual screening in rural south India.. International Journal of Cancer 2004;109(3):461-7.

\section{Sasieni 1996}

Sasieni PD, Cuzick J, LynchFarmery E. National Coordinating Networkfor Cervical Screening Working Group. Estimating the efficacy of screening by auditing smear histories of women with and without cervical cancer. British Journal of Cancer 1996;73(8):1001-5.

Sawaya 2003

Sawaya GF, McConnell KJ, Kulasingam SL, Lawson HW, Kerlikowske K, Melnikow J, Lee NC, Gildengorin G, Myers ER, Washington AE. Risk of cervical cancer associated with extending the interval between cervical-cancer screening. New England Journal of Medicine 2003;3649(16):1501-9.

\section{Schneider 1983}

Schneider V, Kay S, Lee HM. Immunosuppression as a highrisk factor in the development or condyloma acuminatum and squamous neoplasia or the cervix. Acta Cytologica 1983; 27:220.

\section{Shepherd 2011}

Shepherd R, Weston J, Peersman G, Napuli IZ. Interventions for encouraging sexual lifestyles and behaviours intended to prevent cervical cancer. Cochrane Database of Systematic Reviews 2011, Issue 4. [DOI: 10.1002/14651858.CD001035]

\section{Tseng 2001}

Tseng DS, Cox E, Plane MB, Hla KM. Efficacy of patient letter reminders on cervical cancer screening: a metaanalysis. Journal of General Internal Medicine 2001;16(8): $563-8$.

\section{Walboomers 1999}

Walboomers, JMM. Human papillomavirus is a necessary cause of invasive cervical cancer worldwide. Journal of Pathology 1999;189(1):12-19.

\section{Webb 2004}

Webb R, Richardson J, Esmail A, Pickles A. Uptake for cervical screening by ethnicity and place-of-birth: a population-based cross-sectional study. Journal for Public Health 2004;26:293-296. 


\section{Yabroff 2003}

Yabroff KR, Mangan P, Mandelblatt J. Effectiveness of

interventions to increase Papanicolaou smear use. Journal of

the American Board of Family Practice 2003;16(3):188-203.

* Indicates the major publication for the study 
CHARACTERISTICS OF STUDIES

\section{Characteristics of included studies [ordered by study ID]}

Adab 2003

\begin{tabular}{ll} 
Methods & $\begin{array}{l}\text { Design - RCT } \\
\text { Baseline comparability - Significantly higher proportion of non-white women in the } \\
\text { intervention group. Otherwise no significant differences between study groups } \\
\text { Follow-up - Nil. }\end{array}$ \\
\hline Participants & $\begin{array}{l}\text { Country - UK } \\
\text { Setting - 3 general practices in Birmingham } \\
\text { Initial screening status - Any } \\
\text { 300 women attending their GP practice. } \\
\text { Inclusion criteria - aged } 20 \text { to } 64 \text { years; } \\
\text { Exclusion criteria - Incomplete questionnaire }\end{array}$ \\
\hline Interventions & $\begin{array}{l}\text { 1. Control leaflet based on that produced by National Health Service Cervical Screening } \\
\text { Programme, though with references to "cervical" cancer, "cervical" screening or "smear } \\
\text { test" removed } \\
\text { 2. Intervention leaflet. As above with additional information on average individual risk } \\
\text { of cervical cancer, possibility of false positive/negative results, uncertainties attached to } \\
\text { screening process, the absolute benefit associated with the screening and the cost of the } \\
\text { process to the NHS }\end{array}$ \\
\hline
\end{tabular}

Outcomes

Self-reporting of "willingness to have study screening test."

Notes

Risk of bias

\begin{tabular}{|c|c|c|}
\hline Bias & Authors' judgement & Support for judgement \\
\hline $\begin{array}{l}\text { Random sequence generation (selection } \\
\text { bias) }\end{array}$ & Low risk & $\begin{array}{l}\text { "Computer generated list of random num- } \\
\text { bers" }\end{array}$ \\
\hline Allocation concealment (selection bias) & Unclear risk & Not reported \\
\hline $\begin{array}{l}\text { Blinding (performance bias and detection } \\
\text { bias) } \\
\text { All outcomes }\end{array}$ & Unclear risk & $\begin{array}{l}\text { Participants were blinded. It is unclear if } \\
\text { outcome assessors were blinded }\end{array}$ \\
\hline $\begin{array}{l}\text { Incomplete outcome data (attrition bias) } \\
\text { All outcomes }\end{array}$ & Low risk & $\%$ analysed: $91 \%(274 / 300)$ \\
\hline Selective reporting (reporting bias) & Unclear risk & $\begin{array}{l}\text { Insufficient information to permit judge- } \\
\text { ment }\end{array}$ \\
\hline
\end{tabular}


Adab 2003 (Continued)

\begin{tabular}{|c|c|c|}
\hline Other bias & Unclear risk & $\begin{array}{l}\text { Insufficient information to assess whether } \\
\text { an important risk of bias exists }\end{array}$ \\
\hline
\end{tabular}

\begin{tabular}{|c|c|c|}
\hline Methods & \multicolumn{2}{|c|}{$\begin{array}{l}\text { Design - Cluster RCT } \\
\text { Baseline comparability - no significant differences between study groups } \\
\text { Follow-up - } 3 \text { years. }\end{array}$} \\
\hline Participants & \multicolumn{2}{|c|}{$\begin{array}{l}\text { Country - US } \\
\text { Setting - Workplace } \\
\text { Inclusion criteria - aged } 50 \text { years or older }\end{array}$} \\
\hline Interventions & \multicolumn{2}{|c|}{$\begin{array}{l}\text { 1. Workplace at worksites led by trained peer health advisors } n=1512 \\
\text { 2. No workshops } n=1431\end{array}$} \\
\hline Outcomes & \multicolumn{2}{|c|}{ Pap smear uptake - self-reported } \\
\hline Notes & \multicolumn{2}{|c|}{$\begin{array}{l}\text { Intervention lasted } 16 \text { months. Non-intervention group were provided with skills and } \\
\text { resources to replicate intervention program }\end{array}$} \\
\hline \multicolumn{3}{|l|}{ Risk of bias } \\
\hline Bias & Authors' judgement & Support for judgement \\
\hline $\begin{array}{l}\text { Random sequence generation (selection } \\
\text { bias) }\end{array}$ & Unclear risk & Not reported \\
\hline Allocation concealment (selection bias) & Unclear risk & Not reported \\
\hline $\begin{array}{l}\text { Blinding (performance bias and detection } \\
\text { bias) } \\
\text { All outcomes }\end{array}$ & Unclear risk & Not reported \\
\hline $\begin{array}{l}\text { Incomplete outcome data (attrition bias) } \\
\text { All outcomes }\end{array}$ & High risk & $\%$ analysed: 66\% (2795/4253) \\
\hline Selective reporting (reporting bias) & Unclear risk & $\begin{array}{l}\text { Insufficient information to permit judge- } \\
\text { ment }\end{array}$ \\
\hline Other bias & Unclear risk & $\begin{array}{l}\text { Insufficient information to assess whether } \\
\text { an important risk of bias exists }\end{array}$ \\
\hline
\end{tabular}




\begin{tabular}{ll}
\hline Methods & $\begin{array}{l}\text { Design - RCT } \\
\text { Baseline comparability - no significant differences between study groups } \\
\text { Follow-up - lyear }\end{array}$ \\
\hline Participants & $\begin{array}{l}\text { Country - USA } \\
\text { Setting - HMO } \\
\text { Initial screening status - overdue } \\
\text { Eligible participants were identified from the medical records of the Kaiser Permanente } \\
\text { Health Plan, South California Region (HMO). Half of those eligible ( } \mathrm{n}=7630) \text { were } \\
\text { included in the final analysis } \\
\text { Inclusion criteria - aged } 25 \text { to } 49 \text { years; enrolled in HMO for at least } 3 \text { years; likely to } \\
\text { seek outpatient care at one of the three medical centres } \\
\text { Exclusion criteria - Pap smear within the last } 3 \text { years }\end{array}$ \\
\hline Interventions & $\begin{array}{l}\text { 1. Telephone call } \mathrm{n}=1526 \\
\text { 2. Letter } \mathrm{n}=1526 \\
\text { 3. Memo to woman's primary provider } \mathrm{n}=1526 \\
\text { 4. Chart reminder affixed to outside of woman's medical record } \mathrm{n}=1526 \\
\text { 5. Control group } \mathrm{n}=1526\end{array}$ \\
\hline Outcomes & \begin{tabular}{l} 
Pap smear uptake and costs determined by administrative records \\
\hline Notes
\end{tabular} \\
\hline $\begin{array}{l}\text { No details were provided as to the selection criteria for half of the women who were } \\
\text { entered into the study }\end{array}$ \\
\hline
\end{tabular}

\section{Risk of bias}

\begin{tabular}{|c|c|c|}
\hline Bias & Authors' judgement & Support for judgement \\
\hline $\begin{array}{l}\text { Random sequence generation (selection } \\
\text { bias) }\end{array}$ & Unclear risk & Not reported \\
\hline Allocation concealment (selection bias) & Unclear risk & Not reported \\
\hline $\begin{array}{l}\text { Blinding (performance bias and detection } \\
\text { bias) } \\
\text { All outcomes }\end{array}$ & Unclear risk & Not reported \\
\hline $\begin{array}{l}\text { Incomplete outcome data (attrition bias) } \\
\text { All outcomes }\end{array}$ & Low risk & $\%$ analysed: $7630 / 7630(100 \%)$ \\
\hline Selective reporting (reporting bias) & Unclear risk & $\begin{array}{l}\text { Insufficient information to permit judge- } \\
\text { ment }\end{array}$ \\
\hline Other bias & Unclear risk & $\begin{array}{l}\text { Insufficient information to assess whether } \\
\text { an important risk of bias exists }\end{array}$ \\
\hline
\end{tabular}


Bowman 1995

\begin{tabular}{ll} 
Methods & $\begin{array}{l}\text { Design - RCT } \\
\text { Baseline comparability - no significant differences between study groups } \\
\text { Follow-up - 6 months }\end{array}$ \\
\hline Participants & $\begin{array}{l}\text { Country - Australia } \\
\text { Setting - General practice } \\
\text { Initial screening status - overdue } \\
\text { Over } 7000 \text { potentially eligible women in an Australian community were identified by a } \\
\text { random household survey (developed by the Australian Bureau of Statistics) } \\
\text { Inclusion criteria - aged } 18 \text { to } 70 \text { years } \\
\text { Exclusion criteria - not sexually active; could not speak English; infirm; not at home } \\
\text { when contacted; hysterectomy }\end{array}$ \\
\hline Interventions & $\begin{array}{l}\text { 1. GP reminder letter } \mathrm{n}=255 \\
\text { 2. Women's health clinic invitation } \mathrm{n}=220 \\
\text { 3. Pamphlet } \mathrm{n}=219\end{array}$ \\
4. Control group (not stated) $\mathrm{n}=219$
\end{tabular}

Outcomes

Pap smear uptake determined by administrative records

Notes

Comparison of self-reported uptake and administrative records of uptake indicated that women were very accurate in their self-report of screening when it had actually taken place, but inaccurate in almost a quarter of instances when they stated that it had occurred

\section{Risk of bias}

\begin{tabular}{|c|c|c|}
\hline Bias & Authors' judgement & Support for judgement \\
\hline $\begin{array}{l}\text { Random sequence generation (selection } \\
\text { bias) }\end{array}$ & Unclear risk & Not reported \\
\hline Allocation concealment (selection bias) & Unclear risk & Not reported \\
\hline $\begin{array}{l}\text { Blinding (performance bias and detection } \\
\text { bias) } \\
\text { All outcomes }\end{array}$ & Low risk & $\begin{array}{l}\text { "Interviewers were unaware of which group } \\
\text { in the study women had been assigned to" }\end{array}$ \\
\hline $\begin{array}{l}\text { Incomplete outcome data (attrition bias) } \\
\text { All outcomes }\end{array}$ & High risk & $\begin{array}{l}\text { \% analysed: } 659 / 913(72 \%) \\
\text { GP reminder letter: } 178 / 255 \quad(70 \%) \\
\text { women were analysed ("Thirty-five women } \\
\text { initially assigned to this group were ex- } \\
\text { cluded because of the non-participation of } \\
\text { their GPs"). } \\
\text { Women's health clinic invitation: } 164 / 220 \\
\text { (75\%) women were analysed } \\
\text { Pamphlet: } 162 / 219(74 \%) \text { women were } \\
\text { analysed } \\
\text { Control group: } 155 / 219(71 \%) \text { women } \\
\text { were analysed }\end{array}$ \\
\hline
\end{tabular}


Bowman 1995 (Continued)

\begin{tabular}{|c|c|c|}
\hline Selective reporting (reporting bias) & Unclear risk & $\begin{array}{l}\text { Insufficient information to permit judge- } \\
\text { ment }\end{array}$ \\
\hline Other bias & Unclear risk & $\begin{array}{l}\text { Insufficient information to assess whether } \\
\text { an important risk of bias exists }\end{array}$ \\
\hline
\end{tabular}

\section{Buehler 1997}

\begin{tabular}{ll} 
Methods & $\begin{array}{l}\text { Design - RCT } \\
\text { Baseline comparability - no significant differences between study groups } \\
\text { Follow-up - 2 months and } 6 \text { months }\end{array}$ \\
\hline Participants & $\begin{array}{l}\text { Country - Canada } \\
\text { Setting - Family medicine clinic } \\
\text { Initial screening status - due } \\
\text { Random sample of } 441 \text { women listed as patients of two clinics (one urban and one rural) } \\
\text { affiliated with the Memorial University of Newfoundland } \\
\text { Inclusion criteria - } 18 \text { to } 69 \text { years } \\
\text { Exclusion criteria - Pap smear in past } 3 \text { years; hysterectomy; moved or had records with } \\
\text { clerical errors }\end{array}$ \\
\hline Interventions & $\begin{array}{l}\text { 1. Personal letter and reminder letter } 4 \text { weeks later } \mathrm{n}=221 \\
\text { 2. Control group received no letter } \mathrm{n}=220\end{array}$ \\
\hline Outcomes & Pap smear uptake determined by administrative records \\
\hline Notes & $\begin{array}{l}\text { Sample size calculations did not take into account the lag time between taking tests and } \\
\text { registering tests, which could and did cause the loss of participants }\end{array}$ \\
\hline
\end{tabular}

Risk of bias

\begin{tabular}{|c|c|c|}
\hline Bias & Authors' judgement & Support for judgement \\
\hline $\begin{array}{l}\text { Random sequence generation (selection } \\
\text { bias) }\end{array}$ & Low risk & $\begin{array}{l}\text { "Of the } 1302 \text {... eligible women, we ran- } \\
\text { domly selected } \\
650 \text { using computer-generated numbers". } \\
\text { From the CONSORT flow diagram it ap- } \\
\text { pears that the } 441 \text { women participating in } \\
\text { the trial after exclusions were randomised } \\
\text { in a similar way }\end{array}$ \\
\hline Allocation concealment (selection bias) & Unclear risk & Not reported \\
\hline $\begin{array}{l}\text { Blinding (performance bias and detection } \\
\text { bias) } \\
\text { All outcomes }\end{array}$ & Unclear risk & Not reported \\
\hline
\end{tabular}


Buehler 1997 (Continued)

\begin{tabular}{l|l|l}
\hline $\begin{array}{l}\text { Incomplete outcome data (attrition bias) } \\
\text { All outcomes }\end{array}$ & Low risk & $\begin{array}{l}\text { \% analysed: } 88 \%(386 / 441) \\
\text { By treatment arm: } \\
\text { Personal letter and reminder letter: 178/ } \\
221(81 \%) \\
\text { Control: 208/220 (95\%) }\end{array}$ \\
\hline Selective reporting (reporting bias) & Unclear risk & $\begin{array}{l}\text { Insufficient information to permit judge- } \\
\text { ment }\end{array}$ \\
\hline Other bias & Unclear risk & $\begin{array}{l}\text { Insufficient information to assess whether } \\
\text { an important risk of bias exists }\end{array}$ \\
\hline
\end{tabular}

\section{Burack 1998}

Methods

$\begin{array}{ll} & \text { Baseline comparability - no significant differences between study groups } \\ \text { Follow-up - } 1 \text { year } \\ \text { Before randomisation women were excluded if their last smear was abnormal/insufficient } \\ \text { for cytology (n = 4708); } 140 \text { were excluded from the patient reminder intervention as } \\ \text { they discontinued HMO membership; } 2055 \text { were excluded from the physician reminder } \\ \text { intervention as they did not attend their physician }\end{array}$

Interventions
1. An invitation letter reminding women that they were due for a Pap smear (964 analysed)

2. Reminders for both physician and participants (960 analysed)

3. Reminders for the physicians ( 960 analysed)

4. Control (no reminder to either physicians or participants (964 analysed)

5801 women were randomised but only gives breakdown of women analysed by treatment arm

Pap smear uptake determined by administrative records
Unclear methodology. Two stage randomisation and large numbers of exclusions after first randomisation. Not clear how many women were originally randomised to each of the four study groups

\section{Risk of bias}


Burack 1998 (Continued)

\begin{tabular}{|c|c|c|}
\hline Bias & Authors' judgement & Support for judgement \\
\hline $\begin{array}{l}\text { Random sequence generation (selection } \\
\text { bias) }\end{array}$ & Low risk & $\begin{array}{l}\text { "A two-stage randomization procedure was } \\
\text { used ... At the beginning of the study pe- } \\
\text { riod, the } 5801 \text { women ... were randomly } \\
\text { assigned using a site specific, stratified ran- } \\
\text { domization procedure to receive or not re- } \\
\text { ceive the physician reminder intervention. } \\
\text { Strata were defined by age, previous Pap } \\
\text { smear use, and number of HMO visits } \\
\text { in the preceding year. To avoid overload- } \\
\text { ing the clinics, a separate randomization } \\
\text { was carried out to assign women to pa- } \\
\text { tient reminder intervention. Women who } \\
\text { remained eligible were selected and ran- } \\
\text { domized to patient reminder intervention } \\
\text { on a weekly basis in groups of } 156 \text { " }\end{array}$ \\
\hline Allocation concealment (selection bias) & Unclear risk & Not reported \\
\hline $\begin{array}{l}\text { Blinding (performance bias and detection } \\
\text { bias) } \\
\text { All outcomes }\end{array}$ & Unclear risk & Not reported \\
\hline $\begin{array}{l}\text { Incomplete outcome data (attrition bias) } \\
\text { All outcomes }\end{array}$ & High risk & $\%$ analysed: $66 \%(3848 / 5801)$ \\
\hline Selective reporting (reporting bias) & Unclear risk & $\begin{array}{l}\text { Insufficient information to permit judge- } \\
\text { ment }\end{array}$ \\
\hline Other bias & Unclear risk & $\begin{array}{l}\text { Insufficient information to assess whether } \\
\text { an important risk of bias exists }\end{array}$ \\
\hline
\end{tabular}

Burack 2003

Methods

Design - Cluster RCT

Baseline comparability - no significant differences between study groups

Follow-up - 1 year

\begin{tabular}{ll}
\hline Participants & Country - US, Detroit. \\
Setting - HMO \\
Initial screening status - due \\
Inclusion criteria - aged 40 years or older and had visited a primary car provider at one \\
of the study sites during the two years preceding the intervention period \\
Exclusion criteria - not reported
\end{tabular}


Burack 2003 (Continued)

\begin{tabular}{|c|c|c|}
\hline Outcomes & \multicolumn{2}{|c|}{$\begin{array}{l}\text { 1. Sent reminders for Pap smear and mammogram } n=1243 \\
\text { 2. Sent reminders for mammogram only } n=1228\end{array}$} \\
\hline Notes & \multicolumn{2}{|c|}{ Pap smear uptake? from study site records } \\
\hline \multicolumn{3}{|l|}{ Risk of bias } \\
\hline Bias & Authors' judgement & Support for judgement \\
\hline $\begin{array}{l}\text { Random sequence generation (selection } \\
\text { bias) }\end{array}$ & Unclear risk & Not reported \\
\hline Allocation concealment (selection bias) & Unclear risk & Not reported \\
\hline $\begin{array}{l}\text { Blinding (performance bias and detection } \\
\text { bias) } \\
\text { All outcomes }\end{array}$ & Unclear risk & Not reported \\
\hline $\begin{array}{l}\text { Incomplete outcome data (attrition bias) } \\
\text { All outcomes }\end{array}$ & Low risk & $\begin{array}{l}\% \text { analysed: } 100 \%(2471 / 2471) \\
\text { However, loss of participants who may have } \\
\text { moved out of area, not received reminder } \\
\text { etc is not clear }\end{array}$ \\
\hline Selective reporting (reporting bias) & Unclear risk & $\begin{array}{l}\text { Insufficient information to permit judge- } \\
\text { ment }\end{array}$ \\
\hline Other bias & Unclear risk & $\begin{array}{l}\text { Insufficient information to assess whether } \\
\text { an important risk of bias exists }\end{array}$ \\
\hline
\end{tabular}

\section{Byles 1994}

\begin{tabular}{ll} 
Methods & $\begin{array}{l}\text { Design - RCT (cluster) } \\
\text { Baseline comparability - study regions matched on census data } \\
\text { Follow-up - 3 months (TV media and letter), } 6 \text { months (GP intervention) }\end{array}$ \\
\hline Participants & $\begin{array}{l}\text { Country - Australia } \\
\text { Setting - Community } \\
\text { Initial screening status - due and overdue } \\
\text { Nine geographically discrete, regions were selected within three adjacent TV broadcasting } \\
\text { areas. The regions were randomly assigned to the study groups and data gathered on } \\
\text { eligible women through administrative records pre-and post-intervention }\end{array}$ \\
$\begin{array}{l}\text { Inclusion criteria - aged } 18 \text { to } 70 \text { years; English-speaking } \\
\text { Exclusion criteria - physically/intellectually impaired }\end{array}$ \\
\hline Interventions & $\begin{array}{l}\text { 1. TV media campaign } \mathrm{n}=\mathrm{n} / \mathrm{a} \\
\text { 2. TV media combined with invitation letter } \mathrm{n}=\mathrm{n} / \mathrm{a} \\
\text { 3. TV media combined with GP based recruitment through workshops } \mathrm{n}=\mathrm{n} / \mathrm{a} \\
\text { 4. Control } \mathrm{n}=\mathrm{n} / \mathrm{a}\end{array}$ \\
\hline
\end{tabular}


Byles 1994 (Continued)

\begin{tabular}{l|l} 
& $\begin{array}{l}\text { n/a not applicable as data was gathered from administrative records for the regions giving } \\
\text { overall Pap smear attendances during the pre- and post- intervention periods } \\
\text { In the letter intervention group using information gathered from electoral registers (reg- } \\
\text { istration was mandatory) all eligible women were sent a letter }\end{array}$ \\
\hline Outcomes & Pap smear uptake determined by administrative records \\
\hline Notes & $\begin{array}{l}\text { Analysis limited by the } 3 \text { and } 6 \text { month post-intervention follow-up periods, a longer } \\
\text { period was prevented by contamination by a state-wide media campaign. Differential } \\
\text { effects of interventions on outcome for the different regions may reflect different baseline } \\
\text { screening rates that could not be assessed during matching. Unit of allocation different } \\
\text { from unit of analysis and no appropriate account was taken of this is the analysis }\end{array}$ \\
$\begin{array}{l}\text { 1. TV media campaign } \mathrm{n}=\mathrm{n} / \mathrm{a} \\
\text { 2. TV media combined with invitation letter } \mathrm{n}=\mathrm{n} / \mathrm{a} \\
\text { 3. TV media combined with GP based recruitment through workshops } \mathrm{n}=\mathrm{n} / \mathrm{a} \\
\text { 4. Control } \mathrm{n}=\mathrm{n} / \mathrm{a}\end{array}$ \\
\hline
\end{tabular}

Risk of bias

\begin{tabular}{l|l|l}
\hline Bias & Authors' judgement & Support for judgement \\
\hline $\begin{array}{l}\text { Random sequence generation (selection } \\
\text { bias) }\end{array}$ & Unclear risk & Not reported \\
\hline $\begin{array}{l}\text { Allocation concealment (selection bias) } \\
\text { Blinding (performance bias and detection } \\
\text { bias) } \\
\text { All outcomes }\end{array}$ & Unclear risk & Not reported risk \\
\hline $\begin{array}{l}\text { Incomplete outcome data (attrition bias) } \\
\text { All outcomes }\end{array}$ & Unclear risk & Not reported \\
\hline Selective reporting (reporting bias) & Unclear risk & Not reported \\
\hline Other bias & Unclear risk & $\begin{array}{l}\text { Insufficient information to permit judge- } \\
\text { ment }\end{array}$ \\
\hline
\end{tabular}


Byles 1995

\begin{tabular}{|c|c|c|}
\hline Methods & \multicolumn{2}{|c|}{$\begin{array}{l}\text { Design - RCT (cluster) } \\
\text { Baseline comparability - study regions were matched as closely as possible using census } \\
\text { data } \\
\text { Follow-up - } 3 \text { months } \\
28 \% \text { of the letter intervention group did not recall ever receiving the intervention; not } \\
\text { clear how many women were followed-up }\end{array}$} \\
\hline Participants & \multicolumn{2}{|c|}{$\begin{array}{l}\text { Country - Australia } \\
\text { Setting - Community } \\
\text { Initial screening status - due } \\
\text { Three geographically separate postal regions were randomly allocated to different inter- } \\
\text { ventions. Data on eligible women within the regions was gathered via administrative } \\
\text { records pre- and post-intervention } \\
\text { Inclusion criteria - aged } 18 \text { to } 70 \text { years; no Pap smear in previous } 3 \text { years; Australian or } \\
\text { British citizenship } \\
\text { Exclusion criteria - not stated }\end{array}$} \\
\hline Interventions & \multicolumn{2}{|c|}{$\begin{array}{l}\text { 1. Personally addressed letter with simple information about Pap smears } \mathrm{n}=\text { ? ( } 959 \\
\text { analysed) ( } 99 \text { attended for screening) } \\
\text { 2. Personally addressed letter combined with a series of targeted behavioural prompts (e. } \\
\text { g. prompt cards) designed to address aspects believed to be associated with poor screening } \\
\text { rates } \mathrm{n}=\text { ? ( } 933 \text { analysed) ( } 95 \text { attended for screening) } \\
\text { 3. Control } \mathrm{n}=\text { ? ( } 1202 \text { analysed) ( } 97 \text { attended for screening) }\end{array}$} \\
\hline Outcomes & \multicolumn{2}{|c|}{ Pap smear uptake determined by administrative records } \\
\hline Notes & \multicolumn{2}{|c|}{$\begin{array}{l}\text { Timescale of the intervention was not stated and the } 3 \text { month follow-up period was } \\
\text { short and may have limited the results. Unit of allocation different from unit of analysis } \\
\text { and no appropriate account was taken of this in the analysis. Unclear how many women } \\
\text { were followed-up }\end{array}$} \\
\hline \multicolumn{3}{|l|}{ Risk of bias } \\
\hline Bias & Authors' judgement & Support for judgement \\
\hline $\begin{array}{l}\text { Random sequence generation (selection } \\
\text { bias) }\end{array}$ & Unclear risk & Not reported \\
\hline Allocation concealment (selection bias) & Unclear risk & Not reported \\
\hline $\begin{array}{l}\text { Blinding (performance bias and detection } \\
\text { bias) } \\
\text { All outcomes }\end{array}$ & Unclear risk & Not reported \\
\hline $\begin{array}{l}\text { Incomplete outcome data (attrition bias) } \\
\text { All outcomes }\end{array}$ & Unclear risk & Not reported \\
\hline Selective reporting (reporting bias) & Unclear risk & $\begin{array}{l}\text { Insufficient information to permit judge- } \\
\text { ment }\end{array}$ \\
\hline
\end{tabular}


Byles 1995 (Continued)

\begin{tabular}{|c|c|c|}
\hline Other bias & Unclear risk & $\begin{array}{l}\text { Insufficient information to assess whether } \\
\text { an important risk of bias exists }\end{array}$ \\
\hline
\end{tabular}

\section{Byles 1996}

\begin{tabular}{ll} 
Methods & $\begin{array}{l}\text { Design - RCT (cluster) } \\
\text { Baseline comparability - regions were matched as closely as possible using census data } \\
\text { Follow-up - 3months } \\
\text { A } 15 \% \text { adjustment of the denominator was made to account for the estimated hysterec- } \\
\text { tomy rate }\end{array}$ \\
\hline Participants & $\begin{array}{l}\text { Country - Australia } \\
\text { Setting - Community } \\
\text { Initial screening status - due and overdue } \\
\text { Nine geographically distinct postal regions were randomly allocated to one of the inter- } \\
\text { vention groups. Data about the women within the regions were gathered pre- and post- } \\
\text { intervention using administrative records } \\
\text { Inclusion criteria - aged } 18 \text { to } 70 \text { years; no Pap smear in the previous } 3 \text { years } \\
\text { Exclusion criteria - not stated }\end{array}$ \\
\hline $\begin{array}{l}\text { 1. Personalised letter advising women to attend screening and providing simple infor- } \\
\text { mation Followed up by a second mailing campaign } 3 \text { years later } \mathrm{n}=\text { ? (? analysed) }\end{array}$ \\
$\begin{array}{l}\text { 2. No letter in the first mailing but letter sent during second mailing 3years later } \mathrm{n}=? \\
\text { (? analysed) } \\
\text { 3. Control, no letter on either occasion } \mathrm{n}=\text { ? (? analysed) }\end{array}$ \\
\hline \multirow{2}{*}{\begin{tabular}{l} 
Interventions \\
\hline
\end{tabular}}
\end{tabular}

Outcomes

Pap smear uptake determined by administrative records

Notes
Previous campaigns may have had an unknown influence on the current campaign. The
iterative process used to provide estimates of expected and observed may be affected
by the limited follow-up period, questioning the reliability of the analysis. Participants
were only partially randomised (to initial letter). Unit of allocation different from unit
of analysis and no appropriate account taken of this in the analysis

Risk of bias

\begin{tabular}{|c|c|c|}
\hline Bias & Authors' judgement & Support for judgement \\
\hline $\begin{array}{l}\text { Random sequence generation (selection } \\
\text { bias) }\end{array}$ & Unclear risk & Not reported \\
\hline Allocation concealment (selection bias) & Unclear risk & Not reported \\
\hline $\begin{array}{l}\text { Blinding (performance bias and detection } \\
\text { bias) } \\
\text { All outcomes }\end{array}$ & Unclear risk & Not reported \\
\hline
\end{tabular}


Byles 1996 (Continued)

\begin{tabular}{l|l|l}
\hline $\begin{array}{l}\text { Incomplete outcome data (attrition bias) } \\
\text { All outcomes }\end{array}$ & Unclear risk & Not reported \\
\hline Selective reporting (reporting bias) & Unclear risk & $\begin{array}{l}\text { Insufficient information to permit judge- } \\
\text { ment }\end{array}$ \\
\hline Other bias & Unclear risk & $\begin{array}{l}\text { Insufficient information to assess whether } \\
\text { an important risk of bias exists }\end{array}$ \\
\hline
\end{tabular}

\section{Clementz 1990}

\begin{tabular}{|c|c|}
\hline Methods & $\begin{array}{l}\text { Design - RCT } \\
\text { Baseline comparability - no differences in any of the variables examined } \\
\text { Follow-up - } 4 \text { months }\end{array}$ \\
\hline Participants & $\begin{array}{l}\text { Country - USA } \\
\text { Setting - University family medicine clinic } \\
\text { Initial screening status - due } \\
220 \text { female patients attending ambulatory clinic } \\
\text { Inclusion criteria - aged } 50 \text { to } 69 \text { years } \\
\text { Exclusion criteria - symptomatic for cervical cancer; previously had cancer }\end{array}$ \\
\hline Interventions & $\begin{array}{l}\text { 1. Personalised GPs letter, one month before due date of tests with an educational } \\
\text { component } n=116 \\
\text { 2. Control group received usual care (not described) } n=104\end{array}$ \\
\hline Outcomes & Pap smear uptake determined by administrative records \\
\hline Notes & $\begin{array}{l}\text { Authors offered no explanation as to why the recall intervention had an adverse effect on } \\
\text { people attending cervical screening, i.e. why such an intervention would make people } \\
\text { less likely to attend. The low power of the study was attributed to imbalances between } \\
\text { the intervention and control groups. There was an additional imbalance as a result of } \\
\text { excluding patients post-randomisation }\end{array}$ \\
\hline
\end{tabular}

Risk of bias

\begin{tabular}{|c|c|c|}
\hline Bias & Authors' judgement & Support for judgement \\
\hline $\begin{array}{l}\text { Random sequence generation (selection } \\
\text { bias) }\end{array}$ & Low risk & $\begin{array}{l}\text { "Patients were then assigned by a com- } \\
\text { puter-generated random number to two } \\
\text { groups" }\end{array}$ \\
\hline Allocation concealment (selection bias) & High risk & Not reported \\
\hline $\begin{array}{l}\text { Blinding (performance bias and detection } \\
\text { bias) } \\
\text { All outcomes }\end{array}$ & Unclear risk & $\begin{array}{l}\text { "The physicians remained blinded to the } \\
\text { individual patient's status throughout the } \\
\text { study". However it was unclear whether or }\end{array}$ \\
\hline
\end{tabular}


Clementz 1990 (Continued)

not the outcome assessors were blinded

\begin{tabular}{l|l|l}
\hline $\begin{array}{l}\text { Incomplete outcome data (attrition bias) } \\
\text { All outcomes }\end{array}$ & Low risk & $\begin{array}{l}\text { \% analysed: 178/220 (81\%) } \\
\text { By treatment arms: } \\
\text { Personalised GPs letter: 102/116 (88\%) } \\
\text { Control: 76/104 (73\%) }\end{array}$ \\
\hline Selective reporting (reporting bias) & Unclear risk & $\begin{array}{l}\text { Insufficient information to permit judge- } \\
\text { ment }\end{array}$ \\
\hline Other bias & Unclear risk & $\begin{array}{l}\text { Insufficient information to assess whether } \\
\text { an important risk of bias exists }\end{array}$ \\
\hline
\end{tabular}

\section{Del Mar 1998}

\begin{tabular}{|c|c|}
\hline Methods & $\begin{array}{l}\text { Design - RCT } \\
\text { Baseline comparability - no differences in age and postcode area } \\
\text { Follow-up - } 1 \text { year }\end{array}$ \\
\hline Participants & $\begin{array}{l}\text { Country - Australia } \\
\text { Setting - Community } \\
\text { Initial screening status - due and overdue } \\
689 \text { women on the electoral roll in South Brisbane } \\
\text { Inclusion criteria - aged } 18 \text { to } 67 \text { years; Vietnamese } \\
\text { Exclusion criteria - not stated }\end{array}$ \\
\hline Interventions & $\begin{array}{l}\text { Media campaign on cervical screening introduced for whole region } 2 \text { months before } \\
\text { letters sent } \\
\text { 1. Personal letter (in Vietnamese) informing them about screening and its benefits } n= \\
359 \\
\text { 2. Control group did not receive a letter } n=330\end{array}$ \\
\hline Outcomes & Pap smear uptake determined by administrative records \\
\hline Notes & $\begin{array}{l}\text { Women in both groups were drawn from the Vietnamese community resident in one } \\
\text { area, so there is a possibility of contamination }\end{array}$ \\
\hline
\end{tabular}

\section{Risk of bias}

\begin{tabular}{lll}
\hline Bias & Authors judgement & Support for judgement \\
\hline $\begin{array}{l}\text { Random sequence generation (selection } \\
\text { bias) }\end{array}$ & Unclear risk & Not reported \\
\hline Allocation concealment (selection bias) & Unclear risk & Not reported \\
\hline $\begin{array}{l}\text { Blinding (performance bias and detection } \\
\text { bias) }\end{array}$ & Low risk & $\begin{array}{l}\text { "After each pathology service had supplied } \\
\text { the dates and results for each woman, the }\end{array}$ \\
\hline
\end{tabular}


Del Mar 1998 (Continued)

\begin{tabular}{|c|c|c|}
\hline All outcomes & & $\begin{array}{l}\text { dataset was stripped of } \\
\text { its fields of names and dates of birth, and } \\
\text { the order changed randomly so that no in- } \\
\text { dividual woman's results could be identi- } \\
\text { fied. This file was then analysed" }\end{array}$ \\
\hline $\begin{array}{l}\text { Incomplete outcome data (attrition bias) } \\
\text { All outcomes }\end{array}$ & Low risk & \% analysed: 689/689 (100\%) \\
\hline Selective reporting (reporting bias) & Unclear risk & $\begin{array}{l}\text { Insufficient information to permit judge- } \\
\text { ment }\end{array}$ \\
\hline Other bias & Unclear risk & $\begin{array}{l}\text { Insufficient information to assess whether } \\
\text { an important risk of bias exists }\end{array}$ \\
\hline
\end{tabular}

Eaker 2004

\begin{tabular}{l|l}
\hline Methods & $\begin{array}{l}\text { Design - RCT } \\
\text { Baseline comparability - no significant differences between study groups } \\
\text { Follow-up - 5months }\end{array}$ \\
\hline Participants & $\begin{array}{l}\text { Country - Sweden } \\
\text { Setting - Uppsala county, Sweden } \\
\text { Initial screening status ? Due } \\
\text { Inclusion criteria - aged } 25 \text { to } 59 \text { years, no Pap smear within past } 3 \text { years } \\
\text { Exclusion criteria - had asked to be excluded from call-recall system }\end{array}$ \\
\hline Interventions & $\begin{array}{l}\text { 1. Standard invitation } n=6140 \\
\text { 2. Modified invitation } n=6100\end{array}$ \\
\hline Outcomes & Pap smear uptake determined by national register \\
\hline Notes & $\begin{array}{l}\text { Study includes multiple sequential randomised interventions. In view of sequential effects } \\
\text { on subsequent interventions only primary intervention included in forest plot } \\
\text { Other interventions were reminder letter versus no reminder to women who had not had } \\
\text { smear at } 5 \text { months and then phone reminder versus no phone reminder at } 2 \text { months to } \\
\text { women who had still not had smear flowing reminder letter. Total follow up for whole } \\
\text { study } 12 \text { months }\end{array}$ \\
\hline
\end{tabular}

Risk of bias

\begin{tabular}{l|l|l}
\hline Bias & Authors' judgement & Support for judgement \\
\hline $\begin{array}{l}\text { Random sequence generation (selection } \\
\text { bias) }\end{array}$ & Unclear risk & Not reported \\
\hline Allocation concealment (selection bias) & Low risk & $\begin{array}{l}\text { "Collaborators in the study were blinded to } \\
\text { the women's group assignment." }\end{array}$
\end{tabular}


Eaker 2004 (Continued)

\begin{tabular}{|c|c|c|}
\hline $\begin{array}{l}\text { Blinding (performance bias and detection } \\
\text { bias) } \\
\text { All outcomes }\end{array}$ & Unclear risk & $\begin{array}{l}\text { However "Becasue the end-point was } \\
\text { whether a woman had a Pap smear or not, } \\
\text { none of the collaborators, except the re- } \\
\text { search assistants conducting the phone re- } \\
\text { minder, could influence the decision." }\end{array}$ \\
\hline $\begin{array}{l}\text { Incomplete outcome data (attrition bias) } \\
\text { All outcomes }\end{array}$ & Low risk & $\%$ analysed: $99 \%(12,157 / 12,240)$ \\
\hline Selective reporting (reporting bias) & Unclear risk & $\begin{array}{l}\text { Insufficient information to permit judge- } \\
\text { ment }\end{array}$ \\
\hline Other bias & Unclear risk & $\begin{array}{l}\text { Insufficient information to assess whether } \\
\text { an important risk of bias exists }\end{array}$ \\
\hline
\end{tabular}

\section{Greene 1999}

Methods

Design - RCT

Baseline comparability - not stated

Follow-up - 6 months

\begin{tabular}{ll}
\hline Participants & $\begin{array}{l}\text { Country - USA } \\
\text { Setting - Rural primary care in low income, minority population } \\
\text { Initial screening status - due } \\
273 \text { women presenting for outpatient care who did not have a Pap test during the } \\
\text { preceding year } \\
\text { Inclusion criteria - not stated } \\
\text { Exclusion criteria - not stated }\end{array}$ \\
\hline Interventions & $\begin{array}{l}\text { Based on Social Cognitive Theory and Motivational Interviewing Methods } \\
\text { 1. Usual care } \mathrm{n}=79 \text { (? analysed) received general dietary and health information }\end{array}$ \\
$\begin{array}{l}\text { 2. Cancer education } \mathrm{n}=97 \text { (? analysed) received general information about cervical } \\
\text { cancer risk factors and screening recommendations } \\
\text { 3. Cognitive behavioral intervention } \mathrm{n}=97 \text { (? analysed) received feedback about personal } \\
\text { risk for cancer and engaged in a clinical interview to enhance self-efficacy for preventative } \\
\text { behaviour }\end{array}$ \\
\hline Outcomes & \begin{tabular}{l} 
Pap smear uptake and booking of appointments determined by administrative records \\
\hline Notes
\end{tabular} \\
\hline $\begin{array}{l}\text { Standard clinical procedures to advocate for and provide Pap tests were not withheld } \\
\text { from any of the participants; all study participants received attention in addition to usual } \\
\text { preventative care }\end{array}$ \\
\hline
\end{tabular}

Risk of bias

Bias

Authors' judgement

Support for judgement 
Greene 1999 (Continued)

\begin{tabular}{|c|c|c|}
\hline $\begin{array}{l}\text { Random sequence generation (selection } \\
\text { bias) }\end{array}$ & Unclear risk & Not reported \\
\hline Allocation concealment (selection bias) & Unclear risk & Not reported \\
\hline $\begin{array}{l}\text { Blinding (performance bias and detection } \\
\text { bias) } \\
\text { All outcomes }\end{array}$ & Unclear risk & Not reported \\
\hline $\begin{array}{l}\text { Incomplete outcome data (attrition bias) } \\
\text { All outcomes }\end{array}$ & Unclear risk & Not reported \\
\hline Selective reporting (reporting bias) & Unclear risk & $\begin{array}{l}\text { Insufficient information to permit judge- } \\
\text { ment }\end{array}$ \\
\hline Other bias & Unclear risk & $\begin{array}{l}\text { Insufficient information to assess whether } \\
\text { an important risk of bias exists }\end{array}$ \\
\hline
\end{tabular}

\section{Hunt 1998}

\begin{tabular}{|c|c|}
\hline Methods & $\begin{array}{l}\text { Design - RCT } \\
\text { Baseline comparability - no significant differences between the study groups in terms the } \\
\text { factors investigated } \\
\text { Follow-up - } 3 \text { months } \\
97 / 119(81.5 \%) \text { of women in the personal approach group and } 37 / 125(30 \%) \text { of in the } \\
\text { letter group were not contacted. These women were included in the final analysis }\end{array}$ \\
\hline Participants & $\begin{array}{l}\text { Country - Australia } \\
\text { Setting - Community } \\
\text { Initial screening status - overdue } \\
372 \text { women identified from files at a women's clinic staffed by Aboriginal health workers } \\
\text { in Danila Bilba } \\
\text { Inclusion criteria - resident in the Darwin area; overdue for screening } \\
\text { Exclusion criteria - not stated }\end{array}$ \\
\hline Interventions & $\begin{array}{l}\text { 1. Personal approach. Women approached by Aboriginal health workers and invited for } \\
\text { screening ( } 119 \text { analysed) } \\
\text { 2. Letter. Designed by Aboriginal workers stating individual overdue for smear and } \\
\text { inviting them to attend ( } 125 \text { analysed) } \\
\text { 3. Control. Usual care with reminder tags for clinic staff attached to medical records } \\
\text { (122 analysed) } \\
372 \text { women were randomised but only gives breakdown of women analysed by treatment } \\
\text { arm }\end{array}$ \\
\hline Outcomes & Pap smear uptake determined by administrative records \\
\hline Notes & $\begin{array}{l}\text { Women were included in the final analysis even though in many cases, particularly in } \\
\text { the personal approach group, they had not received the intervention. The } 3 \mathrm{mth} \text { follow- }\end{array}$ \\
\hline
\end{tabular}




\section{Hunt 1998 (Continued)}

up period is relatively short

\begin{tabular}{|c|c|c|}
\hline Bias & Authors' judgement & Support for judgement \\
\hline $\begin{array}{l}\text { Random sequence generation (selection } \\
\text { bias) }\end{array}$ & Low risk & $\begin{array}{l}\text { "Women were randomly allocated to one } \\
\text { of three groups by matching a list of the } \\
\text { women's file numbers to a list of com- } \\
\text { puter-generated random numbers desig- } \\
\text { nating the group number }(1,2 \text { or } 3) \text { " }\end{array}$ \\
\hline Allocation concealment (selection bias) & Unclear risk & Not reported \\
\hline $\begin{array}{l}\text { Blinding (performance bias and detection } \\
\text { bias) } \\
\text { All outcomes }\end{array}$ & Low risk & $\begin{array}{l}\text { "The person reviewing the files }(\mathrm{JH}) \text { was } \\
\text { not aware } \\
\text { of the women's group allocation, and was } \\
\text { not involved in sending letters or con- } \\
\text { tacting women in the personal approach } \\
\text { group" }\end{array}$ \\
\hline $\begin{array}{l}\text { Incomplete outcome data (attrition bias) } \\
\text { All outcomes }\end{array}$ & Low risk & $\%$ analysed: $98 \%(366 / 372)$ \\
\hline Selective reporting (reporting bias) & Unclear risk & $\begin{array}{l}\text { Insufficient information to permit judge- } \\
\text { ment }\end{array}$ \\
\hline Other bias & Unclear risk & $\begin{array}{l}\text { Insufficient information to assess whether } \\
\text { an important risk of bias exists }\end{array}$ \\
\hline
\end{tabular}

\section{Kreuter 1996}

\begin{tabular}{ll} 
Methods & $\begin{array}{l}\text { Design - RCT } \\
\text { Baseline comparability - no significant differences between the study groups in terms of } \\
\text { demographic variables }\end{array}$ \\
& $\begin{array}{l}\text { Follow-up - } 6 \text { months } \\
186 / 1317 \text { failed to complete the } 6 \mathrm{mth} \text { follow-up questionnaire; } 457 / 1131 \text { were not } \\
\text { considered to be at risk or did not want to change and so were not included in the final } \\
\text { analysis }\end{array}$ \\
\hline Participants & Country - USA \\
\hline Setting - Family medical practice \\
Initial screening status - unclear \\
1317 adult patients from eight family medical practices in North Carolina, USA \\
Inclusion criteria - aged 18 to 75 years; completed baseline survey \\
Exclusion criteria - not stated
\end{tabular}


Kreuter 1996 (Continued)

\begin{tabular}{ll}
\hline Interventions & Based on Health Belief Model \\
1. Typical HRA-computerised assessment of participants' health risks and provision of \\
individualised feedback as to their calculated mortality risks $\mathrm{n}=427$ \\
2. Enhanced HRA-as previous but also assesses benefits, barriers and other psychosocial \\
factors influencing the individuals' health related behaviour in order to provide individ- \\
ualised feedback designed to facilitate self change in health behaviours $\mathrm{n}=427$ \\
3. Control-no feedback given to participants $\mathrm{n}=463$
\end{tabular}

\begin{tabular}{l|l} 
Outcomes & Pap smear uptake determined by self report via questionnaire \\
\hline Notes & $\begin{array}{l}\text { Also mentions the Precaution Adaption Model. Absolute values for the original number } \\
\text { of individuals eligible to receive the tests at baseline not stated }\end{array}$
\end{tabular}

\section{Risk of bias}

\begin{tabular}{|c|c|c|}
\hline Bias & Authors' judgement & Support for judgement \\
\hline $\begin{array}{l}\text { Random sequence generation (selection } \\
\text { bias) }\end{array}$ & Unclear risk & Not reported \\
\hline Allocation concealment (selection bias) & Unclear risk & Not reported \\
\hline $\begin{array}{l}\text { Blinding (performance bias and detection } \\
\text { bias) } \\
\text { All outcomes }\end{array}$ & Unclear risk & Not reported \\
\hline $\begin{array}{l}\text { Incomplete outcome data (attrition bias) } \\
\text { All outcomes }\end{array}$ & High risk & $\begin{array}{l}\% \text { analysed: } 126 / 1317(10 \%) \\
\text { By treatment arm: } \\
\text { Typical HRA-computerised assessment: } \\
46 / 427(11 \%) \\
\text { Enhanced HRA: } 48 / 427(11 \%) \\
\text { Control: } 32 / 463(7 \%)\end{array}$ \\
\hline Selective reporting (reporting bias) & Unclear risk & $\begin{array}{l}\text { Insufficient information to permit judge- } \\
\text { ment }\end{array}$ \\
\hline Other bias & Unclear risk & $\begin{array}{l}\text { Insufficient information to assess whether } \\
\text { an important risk of bias exists }\end{array}$ \\
\hline
\end{tabular}

\section{Lancaster 1992}

\section{Methods}

Design - RCT

Baseline comparability - no significant differences between study groups in terms of mean age

Follow-up - not stated 
Lancaster 1992 (Continued)

\begin{tabular}{|c|c|c|}
\hline Participants & \multicolumn{2}{|c|}{$\begin{array}{l}\text { Country - UK } \\
\text { Setting - General practice } \\
\text { Initial screening status - due } \\
2131 \text { women registered with general practices in North Manchester } \\
\text { Inclusion criteria - aged } 50 \text { to } 64 \text { years; resident in study area } \\
\text { Exclusion criteria - hysterectomy }\end{array}$} \\
\hline Interventions & \multicolumn{2}{|c|}{$\begin{array}{l}\text { 1. Cervical screening invitation sent with breast screening invitation } n=965 \\
\text { 2. Breast screening invitation only sent (control) } n=947\end{array}$} \\
\hline Outcomes & \multicolumn{2}{|c|}{ Pap smear uptake determined by administrative records } \\
\hline Notes & \multicolumn{2}{|c|}{$\begin{array}{l}\text { Eligibility criteria for participation in the study and for breast and cervical screening } \\
\text { were not explicit. Ineligible women were included in the initial randomisation }\end{array}$} \\
\hline \multicolumn{3}{|l|}{ Risk of bias } \\
\hline Bias & Authors' judgement & Support for judgement \\
\hline $\begin{array}{l}\text { Random sequence generation (selection } \\
\text { bias) }\end{array}$ & Unclear risk & Not reported \\
\hline Allocation concealment (selection bias) & Unclear risk & Not reported \\
\hline $\begin{array}{l}\text { Blinding (performance bias and detection } \\
\text { bias) } \\
\text { All outcomes }\end{array}$ & Unclear risk & Not reported \\
\hline $\begin{array}{l}\text { Incomplete outcome data (attrition bias) } \\
\text { All outcomes }\end{array}$ & Low risk & $\begin{array}{l}\text { \% analysed: } 1794 / 1912(94 \%) \\
\text { By treatment arm: } \\
\text { Cervical screening invitation: } 908 / 965 \\
(94 \%) \\
\text { Control: } 886 / 947(94 \%)\end{array}$ \\
\hline Selective reporting (reporting bias) & Unclear risk & $\begin{array}{l}\text { Insufficient information to permit judge- } \\
\text { ment }\end{array}$ \\
\hline Other bias & Unclear risk & $\begin{array}{l}\text { Insufficient information to assess whether } \\
\text { an important risk of bias exists }\end{array}$ \\
\hline
\end{tabular}


McAvoy 1991

\begin{tabular}{l|l}
\hline Methods & $\begin{array}{l}\text { Design - RCT } \\
\text { Baseline comparability - not stated } \\
\text { Follow-up - 2 months and } 4 \text { months } \\
\text { The overall response and consent rate was } 73 \%\end{array}$ \\
\hline Participants & $\begin{array}{l}\text { Country - UK } \\
\text { Setting - National screening programme } \\
\text { Initial screening status - overdue } \\
737 \text { randomly selected women from the Asian community in Leicester } \\
\text { Inclusion criteria - resident of Leicester; aged } 18 \text { to } 52 \text { years; not recorded as having had } \\
\text { a smear test }\end{array}$ \\
\hline Exclusion criteria - not stated \\
\hline Interventions & $\begin{array}{l}\text { 1. Home visit and a multilingual video } \mathrm{n}=263 \\
\text { 2. Home visit, multilingual leaflet and fact sheet } \mathrm{n}=219 \\
\text { 3. Posted multilingual leaflet and fact sheet } \mathrm{n}=131 \\
\text { 4. Control group received no intervention } \mathrm{n}=124\end{array}$ \\
\hline Outcomes & \begin{tabular}{l} 
Pap smear uptake determined by administrative records \\
\hline Notes
\end{tabular} \\
\hline $\begin{array}{l}\text { Sample may not be representative of the general population as it uses only Asian partici- } \\
\text { pants and originates from a previous study on use of health services. The sample had an } \\
\text { over- representation of Moslems }\end{array}$ \\
\hline
\end{tabular}

\section{Risk of bias}

\begin{tabular}{|c|c|c|}
\hline Bias & Authors' judgement & Support for judgement \\
\hline $\begin{array}{l}\text { Random sequence generation (selection } \\
\text { bias) }\end{array}$ & Low risk & $\begin{array}{l}\text { The study appears to have used a min- } \\
\text { imisation technique, where an attempt was } \\
\text { made to minimise the imbalance between } \\
\text { the number of patients in each treatment } \\
\text { group over a number of factors; "The final } \\
\text { sample was stratified by age, religion, post- } \\
\text { code area, and by participation in the pre- } \\
\text { vious study (either as respondents or non- } \\
\text { respondents) and then divided into four } \\
\text { groups" }\end{array}$ \\
\hline Allocation concealment (selection bias) & Unclear risk & Not reported \\
\hline $\begin{array}{l}\text { Blinding (performance bias and detection } \\
\text { bias) } \\
\text { All outcomes }\end{array}$ & Unclear risk & Not reported \\
\hline $\begin{array}{l}\text { Incomplete outcome data (attrition bias) } \\
\text { All outcomes }\end{array}$ & Low risk & \% analysed: $737 / 737(100 \%)$ \\
\hline
\end{tabular}


McAvoy 1991 (Continued)

\begin{tabular}{|c|c|c|}
\hline Selective reporting (reporting bias) & Unclear risk & $\begin{array}{l}\text { Insufficient information to permit judge- } \\
\text { ment }\end{array}$ \\
\hline Other bias & Unclear risk & $\begin{array}{l}\text { Insufficient information to assess whether } \\
\text { an important risk of bias exists }\end{array}$ \\
\hline
\end{tabular}

\section{McDowell 1989}

\begin{tabular}{ll}
\hline Methods & $\begin{array}{l}\text { Design - RCT } \\
\text { Baseline comparability - no significant differences between study groups in terms of } \\
\text { marital status and age } \\
\text { Follow-up - 1 year } \\
447 / 2034 \text { women who were not due for screening were excluded pre-randomisation }\end{array}$ \\
\hline Participants & $\begin{array}{l}\text { Country - Canada } \\
\text { Setting - Hospital } \\
\text { Initial screening status - due and overdue } \\
\text { 2034 female patients attending a hospital-based family medical center in Ottawa } \\
\text { Inclusion criteria - aged } 18 \text { to } 35 \text { years; no previous smear in past year } \\
\text { Exclusion criteria - not stated }\end{array}$ \\
\hline Interventions & $\begin{array}{l}\text { 1. GP letter and reminder letter after } 21 \text { days } n=367 \\
\text { 2. Physician reminder } n=332 \\
\text { 3. Telephone call } n=377 \\
\text { 4. Control group } n=330\end{array}$ \\
\hline Outcomes & \begin{tabular}{l} 
Pap smear uptake and costs determined by administrative records \\
\hline Notes
\end{tabular} \\
\hline $\begin{array}{l}\text { Study also incorporated } 628 / 2034 \text { women who were assigned to a practice control group, } \\
\text { but these women were not randomly assigned. By not assessing the eligibility of women } \\
\text { (ie whether they had a smear in the preceding year) a number of women were excluded } \\
\text { from the study post- randomisation }\end{array}$ \\
\hline
\end{tabular}

\section{Risk of bias}

\begin{tabular}{l|ll}
\hline Bias & Authors' judgement & Support for judgement \\
\hline $\begin{array}{l}\text { Random sequence generation (selection } \\
\text { bias) }\end{array}$ & Unclear risk & Not reported \\
\hline $\begin{array}{l}\text { Allocation concealment (selection bias) } \\
\text { Blinding (performance bias and detection } \\
\text { bias) } \\
\text { All outcomes }\end{array}$ & Unclear risk & Not reported \\
\hline $\begin{array}{l}\text { Incomplete outcome data (attrition bias) } \\
\text { All outcomes }\end{array}$ & Low risk & Not reported \\
\hline
\end{tabular}


McDowell 1989 (Continued)

\begin{tabular}{|c|c|c|}
\hline Selective reporting (reporting bias) & Unclear risk & $\begin{array}{l}\text { Insufficient information to permit judge- } \\
\text { ment }\end{array}$ \\
\hline Other bias & Unclear risk & $\begin{array}{l}\text { Insufficient information to assess whether } \\
\text { an important risk of bias exists }\end{array}$ \\
\hline
\end{tabular}

\section{Mock 2007}

\begin{tabular}{ll}
\hline Methods & $\begin{array}{l}\text { Design - Cluster RCT } \\
\text { Baseline comparability - No significant differences between study groups } \\
\text { Follow-up - “3 to 4 months”. }\end{array}$ \\
\hline Participants & $\begin{array}{l}\text { Country - US, Santa Clara County, California } \\
\text { Setting - Vietnamese-American community } \\
\text { Initial screening status - due } \\
\text { Inclusion criteria - aged } 18 \text { years or older living in Santa Clara county, California } \\
\text { Exclusion criteria - Not reported }\end{array}$ \\
\hline
\end{tabular}

Interventions

1. Lay health worker intervention involving presentations about cervical cancer, question and answer sessions, and regular contact with participants to explain and access to and scheduling of appointments. Also had media intervention $(n=491)$.

2. Media intervention only. Television, radio and print advertisements targeted at the Vietnamese-American female population $(\mathrm{n}=477)$

\begin{tabular}{l|l} 
Outcomes & Pap smear uptake - self-reported post-intervention questionnaire \\
\hline Notes & $\begin{array}{l}\text { Women selected from the social networks of the lay health outreach workers and therefore } \\
\text { may be more motivated to comply }\end{array}$ \\
\hline
\end{tabular}

\section{Risk of bias}

\begin{tabular}{l|ll}
\hline Bias & Authors' judgement & Support for judgement \\
\hline $\begin{array}{l}\text { Random sequence generation (selection } \\
\text { bias) }\end{array}$ & Unclear risk & Not reported \\
\hline Allocation concealment (selection bias) & Unclear risk & Not reported \\
\hline $\begin{array}{l}\text { Blinding (performance bias and detection } \\
\text { bias) } \\
\text { All outcomes }\end{array}$ & Unclear risk & Not reported \\
\hline $\begin{array}{l}\text { Incomplete outcome data (attrition bias) } \\
\text { All outcomes }\end{array}$ & Low risk & \% analysed: 96.3\% (968/1005) \\
\hline \begin{tabular}{l} 
Selective reporting (reporting bias) \\
\hline
\end{tabular} & Unclear risk & $\begin{array}{l}\text { Insufficient information to permit judge- } \\
\text { ment }\end{array}$
\end{tabular}


Mock 2007 (Continued)

\begin{tabular}{|l|l|l|l|l|l}
\hline Other bias & High risk & $\begin{array}{l}\text { Women selected from the social networks } \\
\text { of the lay health outreach workers and } \\
\text { therefore may be more motivated to com- } \\
\text { ply }\end{array}$ \\
\hline
\end{tabular}

\section{Morrell 2005}

\begin{tabular}{|c|c|c|}
\hline Methods & \multicolumn{2}{|c|}{$\begin{array}{l}\text { Design - RCT } \\
\text { Baseline comparability - not reported } \\
\text { Follow-up - } 90 \text { days }\end{array}$} \\
\hline Participants & \multicolumn{2}{|c|}{$\begin{array}{l}\text { Country - Australia } \\
\text { Setting - Community } \\
\text { Initial screening status - due } \\
90,000 \text { women who had not had a Pap smear for } \geq 48 \text { months } \\
\text { Inclusion criteria - age } 20 \text { to } 69 \text { years, not had smear in past } 48 \text { months, on New South } \\
\text { Wales Pap Test Register } \\
\text { Exclusion criteria - not stated }\end{array}$} \\
\hline Interventions & \multicolumn{2}{|c|}{$\begin{array}{l}\text { 1. No intervention } \\
\text { 2. Letter identical to that usually sent out to women at } 27 \text { months after latest Pap smear } \\
\text { or letter giving a similar message, but phrased in a tone more sympathetic to other factors } \\
\text { going on in the woman's life that might have stopped her from having the test to date }\end{array}$} \\
\hline Outcomes & \multicolumn{2}{|c|}{ Pap smear as recorded on New South Wales Pap Test Register } \\
\hline Notes & \multicolumn{2}{|c|}{ Both letter styles were analysed together } \\
\hline \multicolumn{3}{|l|}{ Risk of bias } \\
\hline Bias & Authors' judgement & Support for judgement \\
\hline $\begin{array}{l}\text { Random sequence generation (selection } \\
\text { bias) }\end{array}$ & Unclear risk & Not reported \\
\hline Allocation concealment (selection bias) & Unclear risk & Not reported \\
\hline $\begin{array}{l}\text { Blinding (performance bias and detection } \\
\text { bias) } \\
\text { All outcomes }\end{array}$ & Unclear risk & Not reported \\
\hline $\begin{array}{l}\text { Incomplete outcome data (attrition bias) } \\
\text { All outcomes }\end{array}$ & Low risk & \% analysed: $99 \%(89,699 / 90,247)$ \\
\hline Selective reporting (reporting bias) & Unclear risk & $\begin{array}{l}\text { Insufficient information to permit judge- } \\
\text { ment }\end{array}$ \\
\hline
\end{tabular}


Morrell 2005 (Continued)

\begin{tabular}{|c|c|c|}
\hline Other bias & Unclear risk & $\begin{array}{l}\text { Insufficient information to assess whether } \\
\text { an important risk of bias exists }\end{array}$ \\
\hline
\end{tabular}

\section{Navarro 1995}

\begin{tabular}{|c|c|}
\hline Methods & $\begin{array}{l}\text { Design - RCT (cluster) } \\
\text { Baseline comparability - only one statistically significant difference found, the propor- } \\
\text { tion of women who were employed ( } 17.5 \% \text { control versus } 8.9 \% \text { intervention), but not } \\
\text { regarded as a threat to internal validity } \\
\text { Follow-up - } 6 \text { months } \\
\text { Outcome measure - self-report via interview }\end{array}$ \\
\hline Participants & $\begin{array}{l}\text { Country - USA } \\
\text { Setting - Community } \\
\text { Initial screening status - unclear } \\
500 \text { Latinas in groups of } 10 \text { to } 15 \text { were recruited through 'consejeras' (traditional lay } \\
\text { health workers in the Latino community) and randomly assigned according to their } \\
\text { consejeras to either the intervention or control } \\
\text { Inclusion criteria - not stated } \\
\text { Exclusion criteria - not stated }\end{array}$ \\
\hline Interventions & $\begin{array}{l}\text { Based on Cognitive Social Learning Theory } \\
\text { 1. Por La Vida }(P L V) \text { programme with consejeras }(n=18) \text { taking } 12 \text { weekly educational } \\
\text { sessions with the groups of women } n=274 \\
\text { 2. Control, no PLV programme instead consejeras }(n=18) \text { participated in a'Community } \\
\text { Living Skills' program } n=238\end{array}$ \\
\hline Outcomes & Pap smear uptake determined by self-report via interview \\
\hline Notes & $\begin{array}{l}\text { The generalisability may be limited as the study focuses on US Latinas of low socio- } \\
\text { economic status who have a low level of acculturation. The differences between the } \\
\text { control (Community Living Skills) and intervention (PLV) programmes were not very } \\
\text { clear. Unit of allocation different from unit of analysis but appropriate analysis using } \\
\text { clusters not individuals was performed. The results were presented using both the women } \\
\text { and the Consejera as the units of analysis. The authors state that the results were limited } \\
\text { as the test completion rates for both the pre- and post-test are lower than desired }\end{array}$ \\
\hline
\end{tabular}

Risk of bias

\begin{tabular}{l|ll}
\hline Bias & Authors' judgement & Support for judgement \\
\hline $\begin{array}{l}\text { Random sequence generation (selection } \\
\text { bias) }\end{array}$ & Unclear risk & Not reported \\
\hline $\begin{array}{l}\text { Allocation concealment (selection bias) } \\
\text { Unclear risk }\end{array}$ & Unceported
\end{tabular}


Navarro 1995 (Continued)

\begin{tabular}{|c|c|c|}
\hline $\begin{array}{l}\text { Blinding (performance bias and detection } \\
\text { bias) } \\
\text { All outcomes }\end{array}$ & Unclear risk & Not reported \\
\hline $\begin{array}{l}\text { Incomplete outcome data (attrition bias) } \\
\text { All outcomes }\end{array}$ & High risk & $\begin{array}{l}\text { \% analysed: } 71 \%(361 / 512) \\
\text { PLV programme: } 199 / 274(73 \%) \\
\text { Control: } 162 / 238(68 \%)\end{array}$ \\
\hline Selective reporting (reporting bias) & Unclear risk & $\begin{array}{l}\text { Insufficient information to permit judge- } \\
\text { ment }\end{array}$ \\
\hline Other bias & Unclear risk & $\begin{array}{l}\text { Insufficient information to assess whether } \\
\text { an important risk of bias exists }\end{array}$ \\
\hline
\end{tabular}

\section{Ornstein 1991}

\begin{tabular}{|c|c|}
\hline Methods & $\begin{array}{l}\text { Design - RCT (cluster) } \\
\text { Baseline comparability - study groups differed significantly }(\mathrm{P}=0.0001) \text { in terms of race, } \\
\text { type of insurance and visit frequency } \\
\text { Follow-up - } 1 \text { year } \\
818 / 3833 \text { in the letter intervention groups (letter only; letter + physician reminder) did } \\
\text { not receive the letters }\end{array}$ \\
\hline Participants & $\begin{array}{l}\text { Country - USA } \\
\text { Setting - Family medicine clinic } \\
\text { Initial screening status - due } \\
7,397 \text { participants and } 49 \text { physicians from a university-based medical centre participated } \\
\text { in the study } \\
\text { Inclusion criteria - aged } 18 \text { years and over; not screened in previous } 2 \text { years; 'active' } \\
\text { patient of the family medicine centre (ie had visited clinic in previous } 2 \text { years) } \\
\text { Exclusion criteria - not stated }\end{array}$ \\
\hline Interventions & $\begin{array}{l}\text { 1. Physicians received computerised reminders } \mathrm{n}=1988 \text { participants, } 14 \text { physicians } \\
\text { 2. Participants were sent an invitation to attend followed by another personalised re- } \\
\text { minder letter ( } 6 \text { months later }) \mathrm{n}=1925 \text { participants, } 12 \text { physicians } \\
\text { 3. Both physician and participant reminders } \mathrm{n}=1908 \text { participants, } 13 \text { physicians } \\
\text { 4. Control group, no intervention } \mathrm{n}=1576 \text { participants, } 10 \text { physicians }\end{array}$ \\
\hline Outcomes & Pap smear uptake determined by administrative records \\
\hline Notes & $\begin{array}{l}\text { A number of biases were reported. The study was limited to analyses of attending partic- } \\
\text { ipants; physicians in the } 4 \text { groups were in the same building (blinding was not possible } \\
\text { and the Hawthorne effect may have contributed to some of the improvements); there } \\
\text { were baseline differences in participant characteristics; the unit of allocation (practice } \\
\text { group) was different from unit of analysis (participant) }\end{array}$ \\
\hline
\end{tabular}

\section{Risk of bias}


Ornstein 1991 (Continued)

\begin{tabular}{l|l|l}
\hline Bias & Authors' judgement & Support for judgement \\
\hline $\begin{array}{l}\text { Random sequence generation (selection } \\
\text { bias) }\end{array}$ & Unclear risk & Not reported \\
\hline $\begin{array}{l}\text { Allocation concealment (selection bias) } \\
\text { Blinding (performance bias and detection } \\
\text { bias) } \\
\text { All outcomes }\end{array}$ & Unclear risk & Not reported \\
\hline $\begin{array}{l}\text { Incomplete outcome data (attrition bias) } \\
\text { All outcomes }\end{array}$ & Low risk & Not reported \\
\hline Selective reporting (reporting bias) & Unclear risk & \% analysed: 100\% (7397/7397) \\
\hline \begin{tabular}{l} 
Other bias \\
\hline
\end{tabular} & Unclear risk & $\begin{array}{l}\text { Insufficient information to permit judge- } \\
\text { ment }\end{array}$ \\
\hline
\end{tabular}

\section{Oscarsson 2007}

\begin{tabular}{l|l} 
Methods & $\begin{array}{l}\text { Design - RCT } \\
\text { Baseline comparability - not reported } \\
\text { Follow-up - 1year }\end{array}$ \\
\hline Participants & $\begin{array}{l}\text { Country - Sweden } \\
\text { Setting - Community } \\
\text { Initial screening status - Unclear } \\
800 \text { women selected at random } \\
\text { Inclusion criteria - aged } 28 \text { to } 65 \text { years, resident in Kalmar County, Sweden, no registered } \\
\text { cervical smear during the last } 5 \text { years. } \\
\text { Exclusion criteria - not stated }\end{array}$ \\
\hline Interventions & $\begin{array}{l}\text { 1. Control. No intervention. } \mathrm{n}=400 \\
\text { 2. Intervention included invitation letters, telephone interviews and promotive efforts } \\
\text { for having a cervical smear taken. } \mathrm{n}=400\end{array}$ \\
\hline Outcomes & Pap smear uptake taken from National Populaition Register \\
\hline Notes & $\begin{array}{l}\text { Cost of extra Pap smear gained was calculated 151.36EURO. Smears cost 66.87EURO } \\
\text { each in the intervention group and 16.63EURO in the control group }\end{array}$ \\
\hline Risk of bias & \\
\hline
\end{tabular}

Bias

Authors' judgement

Support for judgement 
Oscarsson 2007 (Continued)

\begin{tabular}{|c|c|c|}
\hline $\begin{array}{l}\text { Random sequence generation (selection } \\
\text { bias) }\end{array}$ & Low risk & $\begin{array}{l}\text { "A computer randomly selected } 400 \\
\text { women to serve as a study group and an- } \\
\text { other } 400 \text { women to serve as a control } \\
\text { group." }\end{array}$ \\
\hline Allocation concealment (selection bias) & Unclear risk & Not reported \\
\hline $\begin{array}{l}\text { Blinding (performance bias and detection } \\
\text { bias) } \\
\text { All outcomes }\end{array}$ & Unclear risk & Not reported \\
\hline $\begin{array}{l}\text { Incomplete outcome data (attrition bias) } \\
\text { All outcomes }\end{array}$ & Low risk & $\%$ analysed:100\% (800/800) \\
\hline Selective reporting (reporting bias) & Unclear risk & $\begin{array}{l}\text { Insufficient information to permit judge- } \\
\text { ment }\end{array}$ \\
\hline Other bias & Unclear risk & $\begin{array}{l}\text { Insufficient information to assess whether } \\
\text { an important risk of bias exists }\end{array}$ \\
\hline
\end{tabular}

\section{Pierce 1989}

Methods

Design - RCT

Baseline comparability - no significant differences were identified between the study groups for any of the characteristics examined

Follow-up - 1 year

$27 \%(38 / 142)$ of women in tagged group did not receive the intervention as they did not consult their doctor during the study period. 61 women were removed from practice list during the study: screening group $(n=24)$, tagged notes group $(n=20)$, control group $(\mathrm{n}=17), \mathrm{n}=3$ died and $\mathrm{n}=58$ left the practices

\begin{tabular}{ll}
\hline Participants & Country - UK \\
& Setting - General practice \\
& Initial screening status - due \\
$146 / 1232$ women registered with a general practice \\
Inclusion criteria - eligible for a smear test \\
Exclusion criteria - smear in past 5 years; hysterectomy; already on call-recall list \\
\hline \multirow{2}{*}{ Interventions } & 1. Letter asking women to have a smear $\mathrm{n}=140$ \\
& 2. Physician reminder $\mathrm{n}=142$ \\
& 3. Control group $\mathrm{n}=134$ \\
\hline
\end{tabular}

Outcomes

Pap smear uptake determined by administrative records

Notes

Risk of bias 
Pierce 1989 (Continued)

\begin{tabular}{l|l|l}
\hline Bias & Authors judgement & Support for judgement \\
\hline $\begin{array}{l}\text { Random sequence generation (selection } \\
\text { bias) }\end{array}$ & Unclear risk & Not reported \\
\hline $\begin{array}{l}\text { Allocation concealment (selection bias) } \\
\text { Blinding (performance bias and detection } \\
\text { bias) } \\
\text { All outcomes }\end{array}$ & Unclear risk & Not reported \\
\hline $\begin{array}{l}\text { Incomplete outcome data (attrition bias) } \\
\text { All outcomes }\end{array}$ & Low risk & Not reported \\
\hline Selective reporting (reporting bias) & Unclear risk & \% analysed: 100\% (416/416) \\
\hline \begin{tabular}{l} 
Other bias \\
\hline
\end{tabular} & Unclear risk & $\begin{array}{l}\text { Insufficient information to permit judge- } \\
\text { ment }\end{array}$ \\
\hline
\end{tabular}

Pritchard 1995

\begin{tabular}{|c|c|}
\hline Methods & $\begin{array}{l}\text { Design - RCT } \\
\text { Baseline comparability - no statistically significant differences between study groups and } \\
\text { all women who attended the practice during the study period for age, country of birth, } \\
\text { marital status and education } \\
\text { Follow-up - } 1 \text { year } \\
22 \text { women in the intervention groups had hysterectomies but were retained in the anal- } \\
\text { yses; } 60 \% \text { of women in the tagged notes group did not receive the intervention }\end{array}$ \\
\hline Participants & $\begin{array}{l}\text { Country - Australia } \\
\text { Setting - General practice } \\
\text { Initial screening status - due } \\
757 / 2139 \text { women at a university general practice in a socio-economically disadvantaged } \\
\text { area of Perth } \\
\text { Inclusion criteria - women aged } 36 \text { to } 69 \text { years } \\
\text { Exclusion criteria - Pap smear in past } 2 \text { years; hysterectomy; no attendance at practice } \\
\text { for } 3 \text { years or more; known to attend another practice; terminally ill }\end{array}$ \\
\hline Interventions & $\begin{array}{l}\text { 1. Physician reminder (tagged notes) group } n=198 \\
\text { 2. Letter with invitation to make an appointment } n=206 \\
\text { 3. Letter with fixed appointment } n=168 \\
\text { 4. Control group (usual care) } n=185\end{array}$ \\
\hline Outcomes & Pap smear uptake determined by administrative records \\
\hline Notes & $\begin{array}{l}\text { Follow-up period was } 1 \text { year and recommended screening interval } 2 \text { years, so some } \\
\text { women may have been screened after study period but within recommended interval }\end{array}$ \\
\hline
\end{tabular}


Pritchard 1995 (Continued)

\begin{tabular}{|c|c|c|}
\hline Bias & Authors' judgement & Support for judgement \\
\hline $\begin{array}{l}\text { Random sequence generation (selection } \\
\text { bias) }\end{array}$ & Low risk & $\begin{array}{l}\text { "Eligible women were randomly allocated } \\
\text { to one of four groups using a table of ran- } \\
\text { dom numbers" }\end{array}$ \\
\hline Allocation concealment (selection bias) & Unclear risk & Not reported \\
\hline $\begin{array}{l}\text { Blinding (performance bias and detection } \\
\text { bias) } \\
\text { All outcomes }\end{array}$ & Unclear risk & Not reported \\
\hline $\begin{array}{l}\text { Incomplete outcome data (attrition bias) } \\
\text { All outcomes }\end{array}$ & Low risk & $\%$ analysed: $100 \%(757 / 757)$ \\
\hline Selective reporting (reporting bias) & Unclear risk & $\begin{array}{l}\text { Insufficient information to permit judge- } \\
\text { ment }\end{array}$ \\
\hline Other bias & Unclear risk & $\begin{array}{l}\text { Insufficient information to assess whether } \\
\text { an important risk of bias exists }\end{array}$ \\
\hline
\end{tabular}

\section{Rimer 1999}

\begin{tabular}{|c|c|}
\hline Methods & $\begin{array}{l}\text { Design - RCT } \\
\text { Baseline comparability - not stated } \\
\text { Follow-up - } 16 \text { months } \\
37 / 889 \text { women died before the follow up interview, and a further } 24 \% \text { could not be } \\
\text { reached due to disconnected phones, } 2 \% \text { were not eligible for follow-up interview due } \\
\text { to health reasons and } 2 \% \text { refused to participate }\end{array}$ \\
\hline Participants & $\begin{array}{l}\text { Country - USA } \\
\text { Setting - Community health centre } \\
\text { Initial screening status - unclear } \\
\text { Adult users (over the age of } 18 \text { years) of the Lincoln Community Health Centre (which } \\
\text { serves } 30 \% \text { of the Black population and is the most important provider of care for low- } \\
\text { income } \\
\text { Inclusion criteria - aged } 18 \text { years or over; client of medical center who had visited center } \\
\text { in previous } 18 \text { months } \\
\text { Exclusion criteria - not stated }\end{array}$ \\
\hline Interventions & $\begin{array}{l}\text { Based on Transtheoretical Model } \\
\text { 1. Provider prompting intervention only ( } 202 \text { analysed) } \\
\text { 2. Provider prompting and tailored educational print communications ( } 204 \text { analysed) } \\
\text { 3. Provider prompting, tailored educational print communications and tailored tele- } \\
\text { phone counselling ( } 213 \text { analysed) } \\
1318 \text { participants (men and women) of whom } 889 \text { eligible women were randomised, }\end{array}$ \\
\hline
\end{tabular}


Rimer 1999 (Continued)

but study only gives breakdown of women analysed by treatment arm

\begin{tabular}{l|l}
\hline Outcomes & Pap smear uptake determined by self-report via questionnaire \\
\hline Notes & $\begin{array}{l}\text { The information presented seem to be part of a larger study looking at the uptake } \\
\text { of cancer screening in general, although only data on female participants attending } \\
\text { mammography, Pap smear and CBE were presented. The use of a telephone to collect } \\
\text { information about participants, as well as part of the interventions may not have been } \\
\text { appropriate as the study looked at screening behaviour among low income participants, } \\
\text { many of whom had to be excluded because their telephone line had been disconnected. } \\
\text { Difficult to assess which part of the invention is effective }\end{array}$ \\
\hline
\end{tabular}

\section{Risk of bias}

\begin{tabular}{l|l|l}
\hline Bias & Authors' judgement & Support for judgement \\
\hline $\begin{array}{l}\text { Random sequence generation (selection } \\
\text { bias) }\end{array}$ & Unclear risk & Not reported \\
\hline $\begin{array}{l}\text { Allocation concealment (selection bias) } \\
\text { Blinding (performance bias and detection } \\
\text { bias) } \\
\text { All outcomes }\end{array}$ & Unclear risk risk & Not reported \\
\hline $\begin{array}{l}\text { Incomplete outcome data (attrition bias) } \\
\text { All outcomes }\end{array}$ & High risk & Not reported \\
\hline Selective reporting (reporting bias) & Unclear risk & \% analysed: 70\% (619/889) \\
\hline \begin{tabular}{l} 
Other bias \\
\hline
\end{tabular} & Unclear risk & $\begin{array}{l}\text { Insufficient information to permit judge- } \\
\text { ment }\end{array}$ \\
\hline
\end{tabular}

Risi 2004

\begin{tabular}{ll} 
Methods & $\begin{array}{l}\text { Design - RCT } \\
\text { Baseline comparability - not reported } \\
\text { Follow-up - } 6 \text { months }\end{array}$ \\
\hline Participants & $\begin{array}{l}\text { Country - South Africa } \\
\text { Setting - Community. Peri-urban squatter community near Cape Town } \\
658 \text { women }\end{array}$ \\
& $\begin{array}{l}\text { Initial screening status - unclear } \\
\text { Inclusion criteria: Women aged } 35 \text { to } 65 \text { years resident in Khayelitsha who gave verbal } \\
\text { consent. } \\
\text { Exclusion criteria - not stated }\end{array}$ \\
\hline
\end{tabular}


Risi 2004 (Continued)

\begin{tabular}{l|l} 
Interventions & $\begin{array}{l}\text { 1. Photo-comic with a storyline including scenarios based on cervical screening and } \\
\text { common reasons for not participating in screening programme. } \mathrm{n}=289 \\
\text { 2. Photo-comic containing no health care messages. } \mathrm{n}=389\end{array}$ \\
\hline Outcomes & Self-reported Pap smear uptake \\
\hline Notes & $\begin{array}{l}\text { After photo-comic intervention, a radio intervention involving similar storylines to the } \\
\text { intervention comic was broadcast. This part of the study was not randomised and is not } \\
\text { included in the analysis in this review }\end{array}$ \\
\hline
\end{tabular}

Risk of bias

\begin{tabular}{|c|c|c|}
\hline Bias & Authors' judgement & Support for judgement \\
\hline $\begin{array}{l}\text { Random sequence generation (selection } \\
\text { bias) }\end{array}$ & Unclear risk & Not reported \\
\hline Allocation concealment (selection bias) & Unclear risk & $\begin{array}{l}\text { "Sealed envelope containing a randomly } \\
\text { allocated photo-comic was provided." No } \\
\text { comment regarding opacity of envelope } \\
\text { made }\end{array}$ \\
\hline $\begin{array}{l}\text { Blinding (performance bias and detection } \\
\text { bias) } \\
\text { All outcomes }\end{array}$ & Unclear risk & Not reported \\
\hline $\begin{array}{l}\text { Incomplete outcome data (attrition bias) } \\
\text { All outcomes }\end{array}$ & Low risk & $\begin{array}{l}>99.8 \% \text { analysed. One subject lost to fol- } \\
\text { low up }\end{array}$ \\
\hline Selective reporting (reporting bias) & Unclear risk & $\begin{array}{l}\text { Insufficient information to permit judge- } \\
\text { ment }\end{array}$ \\
\hline Other bias & Unclear risk & $\begin{array}{l}\text { Insufficient information to assess whether } \\
\text { an important risk of bias exists }\end{array}$ \\
\hline
\end{tabular}

Rivers 2005

\begin{tabular}{ll}
\hline Methods & $\begin{array}{l}\text { Design - RCT } \\
\text { Baseline comparability - Baseline demographics of all women reported, but not broken } \\
\text { down into intervention arms } \\
\text { Follow-up - } 12 \text { months }\end{array}$ \\
\hline Participants & $\begin{array}{l}\text { Country - USA } \\
\text { Setting - Urban community health clinic } \\
441 \text { women participated. Women were approached in the waiting room when attending } \\
\text { the clinic. Women attending for obstetric or gynaecological reasons were not approached. } \\
\text { Initial screening status - unclear } \\
\text { Inclusion criteria: Women aged } 18 \text { to } 65 \text { years. }\end{array}$ \\
\hline
\end{tabular}


Rivers 2005 (Continued)

Exclusion criteria - not stated

\begin{tabular}{l|l}
\hline Interventions & $\begin{array}{l}\text { 1. } 10 \text { minute video focusing on prevention of cervical cancer. Message gain-framed } \\
\text { 2. } 10 \text { minute video focusing on prevention of cervical cancer. Message loss-framed } \\
\text { 3. } 10 \text { minute video focusing on detection of cervical cancer. Message gain-framed } \\
\text { 4. } 10 \text { minute video focusing on detection of cervical cancer. Message loss-framed }\end{array}$ \\
\hline Outcomes & Self-reported uptake of Pap smear \\
\hline Notes & \\
\hline
\end{tabular}

Risk of bias

\begin{tabular}{|c|c|c|}
\hline Bias & Authors' judgement & Support for judgement \\
\hline $\begin{array}{l}\text { Random sequence generation (selection } \\
\text { bias) }\end{array}$ & Low risk & $\begin{array}{l}\text { Computer generated table of randomly } \\
\text { sorted combinations of conditions }\end{array}$ \\
\hline Allocation concealment (selection bias) & Unclear risk & Not reported \\
\hline $\begin{array}{l}\text { Blinding (performance bias and detection } \\
\text { bias) } \\
\text { All outcomes }\end{array}$ & Unclear risk & Not reported \\
\hline $\begin{array}{l}\text { Incomplete outcome data (attrition bias) } \\
\text { All outcomes }\end{array}$ & High risk & $\%$ analysed: $78 \%(343 / 441)$ \\
\hline Selective reporting (reporting bias) & Unclear risk & $\begin{array}{l}\text { Insufficient information to permit judge- } \\
\text { ment }\end{array}$ \\
\hline Other bias & High risk & $\begin{array}{l}\text { Telephone call at } 6 \text { months may have acted } \\
\text { as a prompt to uptake and influence } 12 \\
\text { month data } \\
\text { Number of recruits assigned to each inter- } \\
\text { vention is not stated. We have assumed a } 1 \text { : } \\
\text { 1:1:1 ratio with } 110 \text { in each intervention }\end{array}$ \\
\hline
\end{tabular}

Robson 1989

Methods

Interventions targeted at women to encourage the uptake of cervical screening (Review)

Copyright (C) 201 I The Cochrane Collaboration. Published by John Wiley \& Sons, Ltd.
Design - RCT

Baseline comparability - no significant differences were found between the study groups in terms of the variables examined

Follow-up - 2 years

Women with hysterectomies were excluded from analyses. Trial discontinued after 2 years (versus 3 years), as GPs were no longer willing to exclude half the patients from accessing the health promotion nurse 
Robson 1989 (Continued)

\begin{tabular}{ll}
\hline Participants & $\begin{array}{l}\text { Country - UK } \\
\text { Setting - General practice } \\
\text { Initial screening status - due } \\
\text { Men and women registered with a general practice in inner London (UK) } \\
\text { Inclusion criteria - aged } 30 \text { to } 65 \text { years; registered with practice and living in area } \\
\text { Exclusion criteria - hysterectomy }\end{array}$ \\
\hline Interventions & $\begin{array}{l}\text { 1. Patients had open access to a health promotion nurse and had their risk factors assessed } \\
\text { and followed up by both their GP and the nurse } \mathrm{n}=799 \\
\text { 2. Control, usual care (i.e. managed by GP alone) } \mathrm{n}=806\end{array}$ \\
\hline Outcomes & Pap smear uptake determined by administrative records \\
\hline Notes & \\
\hline
\end{tabular}

\section{Risk of bias}

\begin{tabular}{|c|c|c|}
\hline Bias & Authors' judgement & Support for judgement \\
\hline $\begin{array}{l}\text { Random sequence generation (selection } \\
\text { bias) }\end{array}$ & Low risk & $\begin{array}{l}\text { "Patients ... were included and randomly } \\
\text { allocated } \\
\text { (with random number tables) to control or } \\
\text { intervention } \\
\text { groups". }\end{array}$ \\
\hline Allocation concealment (selection bias) & Unclear risk & Not reported \\
\hline $\begin{array}{l}\text { Blinding (performance bias and detection } \\
\text { bias) } \\
\text { All outcomes }\end{array}$ & Unclear risk & Not reported \\
\hline $\begin{array}{l}\text { Incomplete outcome data (attrition bias) } \\
\text { All outcomes }\end{array}$ & Low risk & $\%$ analysed: $1605 / 1605(100 \%)$ \\
\hline Selective reporting (reporting bias) & Unclear risk & $\begin{array}{l}\text { Insufficient information to permit judge- } \\
\text { ment }\end{array}$ \\
\hline Other bias & High risk & $\begin{array}{l}\text { "Although the trial had been designed to } \\
\text { last three } \\
\text { years, it was stopped after two years because } \\
\text { participating } \\
\text { doctors were not prepared to continue ex- } \\
\text { cluding half the practice from access to the } \\
\text { health promotion nurse" }\end{array}$ \\
\hline
\end{tabular}


Segnan 1998

\begin{tabular}{|c|c|c|}
\hline Methods & \multicolumn{2}{|c|}{$\begin{array}{l}\text { Design - RCT } \\
\text { Baseline comparability - no significant differences were found between the study groups } \\
\text { in terms of the variables examined } \\
\text { Follow-up - } 1 \text { year }\end{array}$} \\
\hline Participants & \multicolumn{2}{|c|}{$\begin{array}{l}\text { Country - Italy } \\
\text { Setting - GP practice in national screening programme } \\
\text { Initial screening status - due } \\
8385 \text { women attending GPs in Turin who were part of the population based screening } \\
\text { programme ('Prevenzione Serena') } \\
\text { Inclusion criteria - aged } 25 \text { to } 64 \text { years; resident of Turin } \\
\text { Exclusion criteria - previously diagnosed cervical cancer;suffering from terminal illness } \\
\text { or severe psychiatric symptoms }\end{array}$} \\
\hline Interventions & \multicolumn{2}{|c|}{$\begin{array}{l}\text { 1. Personal letter signed by GP with prefixed appointment (Control) } n=2100 \\
\text { 2. Personal letter, signed by GP prompting appointment, } n=2093 \\
\text { 3. Personal letter signed by program co-ordinator with prefixed appointment } n=2094 \\
\text { 4. Personal letter with extended text signed by GP with prefixed appointment } n=2098\end{array}$} \\
\hline Outcomes & \multicolumn{2}{|c|}{ Pap smear uptake determined by administrative records } \\
\hline \multicolumn{3}{|l|}{ Notes } \\
\hline \multicolumn{3}{|l|}{ Risk of bias } \\
\hline Bias & Authors' judgement & Support for judgement \\
\hline $\begin{array}{l}\text { Random sequence generation (selection } \\
\text { bias) }\end{array}$ & Low risk & $\begin{array}{l}\text { "Assignment to the different groups was } \\
\text { performed automatically, following a ran- } \\
\text { domised block design (block=GP)" }\end{array}$ \\
\hline Allocation concealment (selection bias) & Unclear risk & Not reported \\
\hline $\begin{array}{l}\text { Blinding (performance bias and detection } \\
\text { bias) } \\
\text { All outcomes }\end{array}$ & Unclear risk & Not reported \\
\hline $\begin{array}{l}\text { Incomplete outcome data (attrition bias) } \\
\text { All outcomes }\end{array}$ & Low risk & $\%$ analysed: $100 \%(8385 / 8385)$ \\
\hline Selective reporting (reporting bias) & Unclear risk & $\begin{array}{l}\text { Insufficient information to permit judge- } \\
\text { ment }\end{array}$ \\
\hline Other bias & Unclear risk & $\begin{array}{l}\text { Insufficient information to assess whether } \\
\text { an important risk of bias exists }\end{array}$ \\
\hline
\end{tabular}


Somkin 1997

\begin{tabular}{|c|c|c|}
\hline Methods & \multicolumn{2}{|c|}{$\begin{array}{l}\text { Design - RCT } \\
\text { Baseline comparability - no differences between study groups in terms of age } \\
\text { Follow-up - } 6 \text { months }\end{array}$} \\
\hline Participants & \multicolumn{2}{|c|}{$\begin{array}{l}\text { Country - USA } \\
\text { Setting - HMO } \\
\text { Initial screening status - due } \\
7077 \text { female HMO members } \\
\text { Inclusion criteria - aged } 20 \text { to } 64 \text { years; no prior Pap smear in the previous } 36 \text { months; } \\
\text { residents of study area; were continuously enrolled as a member of the HMO for the } \\
\text { previous } 36 \text { months } \\
\text { Exclusion criteria - not stated }\end{array}$} \\
\hline Interventions & \multicolumn{2}{|c|}{$\begin{array}{l}\text { 1. Letter inviting women to make an appointment } n=1188 \\
\text { 2. Physician reminder and letter to patient inviting appointment } n=1188 \\
\text { 3. Usual care (required a referral from physician) } n=1188\end{array}$} \\
\hline Outcomes & \multicolumn{2}{|c|}{ Pap smear uptake determined by administrative records } \\
\hline Notes & \multicolumn{2}{|c|}{$\begin{array}{l}\text { The authors list the following study limitations: smears obtained outside the HMO were } \\
\text { not recorded; the chart reminder intervention required the health provider to review the } \\
\text { chart; the study had insufficient power to detect interactions effects between interventions } \\
\text { and covariates, and within strata }\end{array}$} \\
\hline \multicolumn{3}{|l|}{ Risk of bias } \\
\hline Bias & Authors' judgement & Support for judgement \\
\hline $\begin{array}{l}\text { Random sequence generation (selection } \\
\text { bias) }\end{array}$ & Unclear risk & Not reported \\
\hline Allocation concealment (selection bias) & Unclear risk & Not reported \\
\hline $\begin{array}{l}\text { Blinding (performance bias and detection } \\
\text { bias) } \\
\text { All outcomes }\end{array}$ & Unclear risk & Not reported \\
\hline $\begin{array}{l}\text { Incomplete outcome data (attrition bias) } \\
\text { All outcomes }\end{array}$ & Low risk & $\%$ analysed: $100 \%(3564 / 3564)$ \\
\hline Selective reporting (reporting bias) & Unclear risk & $\begin{array}{l}\text { Insufficient information to permit judge- } \\
\text { ment }\end{array}$ \\
\hline Other bias & Unclear risk & $\begin{array}{l}\text { Insufficient information to assess whether } \\
\text { an important risk of bias exists }\end{array}$ \\
\hline
\end{tabular}


Stein 2005

\begin{tabular}{|c|c|c|}
\hline Methods & \multicolumn{2}{|c|}{$\begin{array}{l}\text { Design - RCT } \\
\text { Baseline comparability - no differences between study groups in terms of age } \\
\text { Follow-up - 3months }\end{array}$} \\
\hline Participants & \multicolumn{2}{|c|}{$\begin{array}{l}\text { Country - UK } \\
\text { Setting - Community. Devon, UK. } \\
\text { Initial screening status - overdue. } 1140 \text { women. No record of screening in past } 15 \text { years } \\
\text { Inclusion criteria - aged } 39 \text { to } 64 \text { years; no record of screening in past } 15 \text { years } \\
\text { Exclusion criteria - deceased, not resident in Devon, undergone hysterectomy, severe } \\
\text { learning disability }\end{array}$} \\
\hline Interventions & \multicolumn{2}{|c|}{$\begin{array}{l}\text { 1. Control. No Intervention. } \mathrm{n}=285 \\
\text { 2. Telephone call. Telephone call from experienced research nurse using a prepared script. } \\
\text { Maxiumum of three attempts were made on consecutive days. } \mathrm{n}=285 \\
\text { 3. Letter from Health Authority District Cervical Screening Commisioner on behalf of } \\
\text { National Cervical Screening Programme. } \mathrm{n}=285 \\
\text { 4. Letter from a well known journalist and broadcaster (Claire Rayner) who is also Chair } \\
\text { of the Patients Association. } \mathrm{n}=285\end{array}$} \\
\hline Outcomes & \multicolumn{2}{|c|}{$\begin{array}{l}\text { Pap smear uptake as recorded on the Devon Patient and Practitioners Services Agency } \\
\text { database }\end{array}$} \\
\hline Notes & \multicolumn{2}{|c|}{$\begin{array}{l}\text { Cost effectiveness analysis also performed. Average cost per attender was } £ 145.12 \text { for } \\
\text { telephone call, } £ 14.29 \text { for letter from commissioner and } £ 37.14 \text { for letter from celebrity }\end{array}$} \\
\hline \multicolumn{3}{|l|}{ Risk of bias } \\
\hline Bias & Authors' judgement & Support for judgement \\
\hline $\begin{array}{l}\text { Random sequence generation (selection } \\
\text { bias) }\end{array}$ & Low risk & $\begin{array}{l}\text { "The sample was drawn randomly from the } \\
\text { sampling frame using Microsoft Excel." }\end{array}$ \\
\hline Allocation concealment (selection bias) & Unclear risk & Not reported \\
\hline $\begin{array}{l}\text { Blinding (performance bias and detection } \\
\text { bias) } \\
\text { All outcomes }\end{array}$ & Unclear risk & Not reported \\
\hline $\begin{array}{l}\text { Incomplete outcome data (attrition bias) } \\
\text { All outcomes }\end{array}$ & High risk & \% analysed: $73 \%(304 / 1140)$ \\
\hline Selective reporting (reporting bias) & Unclear risk & $\begin{array}{l}\text { Insufficient information to permit judge- } \\
\text { ment }\end{array}$ \\
\hline Other bias & Unclear risk & $\begin{array}{l}\text { Insufficient information to assess whether } \\
\text { an important risk of bias exists }\end{array}$ \\
\hline
\end{tabular}




\begin{tabular}{|c|c|c|}
\hline Methods & \multicolumn{2}{|c|}{$\begin{array}{l}\text { Design - RCT } \\
\text { Baseline comparability - no significant differences between study groups in terms of } \\
\text { those variables examined } \\
\text { Follow-up - } 6 \text { months }\end{array}$} \\
\hline Participants & \multicolumn{2}{|c|}{$\begin{array}{l}\text { Country - USA } \\
\text { Setting - Community } \\
\text { Initial screening status - due } \\
321 \text { low income African- American women from an inner-city community health centre } \\
\text { Inclusion criteria - African- American; aged } 18 \text { years or older } \\
\text { Exclusion criteria - hysterectomy; history of cervical cancer }\end{array}$} \\
\hline Interventions & \multicolumn{2}{|c|}{$\begin{array}{l}\text { 1. Lay health workers visited women three times to provide a culturally sensitive educa- } \\
\text { tional program emphasising need for screening through printed material and video } \mathrm{n}= \\
163 \\
\text { 2. Control group received educational information on completion of follow-up } \mathrm{n}=158\end{array}$} \\
\hline Outcomes & \multicolumn{2}{|c|}{ Pap smear uptake determined by self-report via interview } \\
\hline Notes & \multicolumn{2}{|c|}{$\begin{array}{l}\text { Loss to follow-up and Hawthorne effect may have biased the effects of the intervention, } \\
\text { however an intention to intervene analysis was also carried out with the aim of providing } \\
\text { a conservative estimate of the effect size }\end{array}$} \\
\hline \multicolumn{3}{|l|}{ Risk of bias } \\
\hline Bias & Authors' judgement & Support for judgement \\
\hline $\begin{array}{l}\text { Random sequence generation (selection } \\
\text { bias) }\end{array}$ & Unclear risk & Not reported \\
\hline Allocation concealment (selection bias) & Unclear risk & Not reported \\
\hline $\begin{array}{l}\text { Blinding (performance bias and detection } \\
\text { bias) } \\
\text { All outcomes }\end{array}$ & Unclear risk & Not reported \\
\hline $\begin{array}{l}\text { Incomplete outcome data (attrition bias) } \\
\text { All outcomes }\end{array}$ & High risk & $\begin{array}{l}\text { \% analysed: } 61 \%(195 / 321) \\
\text { Lay health workers: } 93 / 163(57 \%) \\
\text { Control: } 102 / 158(65 \%)\end{array}$ \\
\hline Selective reporting (reporting bias) & Unclear risk & $\begin{array}{l}\text { Insufficient information to permit judge- } \\
\text { ment }\end{array}$ \\
\hline Other bias & Unclear risk & $\begin{array}{l}\text { Insufficient information to assess whether } \\
\text { an important risk of bias exists }\end{array}$ \\
\hline
\end{tabular}


Taylor 2002

\begin{tabular}{|c|c|c|}
\hline Methods & \multicolumn{2}{|c|}{$\begin{array}{l}\text { Design - RCT } \\
\text { Baseline comparability - no significant differences between study groups in terms of } \\
\text { those variables examined } \\
\text { Follow-up - 6months }\end{array}$} \\
\hline Participants & \multicolumn{2}{|c|}{$\begin{array}{l}\text { Country - USA } \\
\text { Setting - Chinese Community in Seattle and Washington } \\
\text { Initial screening status - Due } \\
\text { Inclusion criteria - } 20 \text { to } 69 \text { years, spoke Cantonese, Mandarin or English; no history } \\
\text { of cervical cancer; not had hysterectomy; not had smear in last } 2 \text { years and/or did not } \\
\text { intend to have Pap smear in the next } 2 \text { years }\end{array}$} \\
\hline Interventions & \multicolumn{2}{|c|}{$\begin{array}{l}\text { 1. Outreach worker intervention: Home visit including videos, motivational pamphlet, } \\
\text { tailored counselling, fact sheet and educational brochure. Follow up with telephone call } \\
\text { with tailored counselling. Assistance also provided to arrange and attend appointment } \\
\text { 2. Direct mail intervention: Packet including video, motivational pamphlet, fact sheet } \\
\text { and educational brochure } \\
\text { 3. Usual care }\end{array}$} \\
\hline Outcomes & \multicolumn{2}{|c|}{$\begin{array}{l}\text { Pap smear within previous } 2 \text { years. Self reported by questionnaire and cross-checked with } \\
\text { medical records where possible }\end{array}$} \\
\hline Notes & \multicolumn{2}{|c|}{$\begin{array}{l}\text { "Groups of women were randomly assigned every month over the } 6 \text {-month period." } \\
\text { Our understanding is that this refers to accrual date rather than referring the quasi- } \\
\text { randomisation } \\
\text { Intention to have smear in next } 2 \text { years also recorded. }\end{array}$} \\
\hline \multicolumn{3}{|l|}{ Risk of bias } \\
\hline Bias & Authors' judgement & Support for judgement \\
\hline $\begin{array}{l}\text { Random sequence generation (selection } \\
\text { bias) }\end{array}$ & Unclear risk & Not reported \\
\hline Allocation concealment (selection bias) & Unclear risk & Not reported \\
\hline $\begin{array}{l}\text { Blinding (performance bias and detection } \\
\text { bias) } \\
\text { All outcomes }\end{array}$ & Unclear risk & Not reported \\
\hline $\begin{array}{l}\text { Incomplete outcome data (attrition bias) } \\
\text { All outcomes }\end{array}$ & Low risk & $\begin{array}{l}\% \text { analysed: } 83 \%(402 / 482) \text { for all out- } \\
\text { comes }\end{array}$ \\
\hline Selective reporting (reporting bias) & Unclear risk & $\begin{array}{l}\text { Insufficient information to permit judge- } \\
\text { ment }\end{array}$ \\
\hline Other bias & Unclear risk & $\begin{array}{l}\text { Insufficient information to assess whether } \\
\text { an important risk of bias exists }\end{array}$ \\
\hline
\end{tabular}




\begin{tabular}{ll} 
Methods & $\begin{array}{l}\text { Design - RCT } \\
\text { Baseline comparability - no significant differences between study groups in terms of } \\
\text { those variables examined } \\
\text { Follow-up - } 12 \text { weeks }\end{array}$ \\
\hline Participants & $\begin{array}{l}\text { Country - USA } \\
\text { Setting - Managed care organisation (NWKP) in Portland, Oregon } \\
\text { Initial screening status - Due } \\
\text { Inclusion criteria - } 18 \text { to } 70 \text { years; } 3 \text { years continuous membership of NWKP; no history } \\
\text { of cervical cancer or cervical dysplasia; not had hysterectomy; not had Pap smear in past } \\
\text { 3 years } \\
\text { Exclusion criteria - women who no longer had a valid local address or phone }\end{array}$ \\
\hline Interventions & $\begin{array}{l}\text { 1. Usual care control } \\
\text { who had not attended for screening within } 6 \text { weeks were sent a further letter emphasising } \\
\text { the importance of screening and providing a number to call }\end{array}$ \\
$\begin{array}{l}\text { 3. Letter/phone intervention: Letter and brochure as above. Women who had not at- } \\
\text { tended for screening within } 6 \text { weeks received a telephone call by study interventionist } \\
\text { who offered to schedule appointments, answer questions, address barriers and concerns } \\
\text { and discussing the importance of screening } \\
\text { 4. Phone/phone intervention: Subjects in this group received two sequential telephone } \\
\text { calls, the second coming } 6 \text { weeks after the first if they had not been screened in the } \\
\text { interim. Contents of the initial letter and phone scripts were similar. Follow-up telephone } \\
\text { calls were by study interventionist, as above }\end{array}$ \\
\hline
\end{tabular}

\begin{tabular}{l|l} 
Outcomes & Pap smear uptake as recorded on care organisation pathology database \\
\hline Notes & $\begin{array}{l}\text { Cost effectiveness analysis also performed. The letter/letter intervention produced one } \\
\text { additional Pap smear for } \$ 185 . \text { The phone/phone intervention cost } \$ 305 \text { and the letter/ } \\
\text { phone intervention cost } \$ 1117 \text { for each additional Pap smear }\end{array}$
\end{tabular}

\section{Risk of bias}

\begin{tabular}{l|l|l}
\hline Bias & Authors' judgement & Support for judgement \\
\hline $\begin{array}{l}\text { Random sequence generation } \\
\text { bias) }\end{array}$ & Unclear risk & Not reported \\
\hline $\begin{array}{l}\text { Allocation concealment (selection bias) } \\
\text { Blinding (performance bias and detection } \\
\text { bias) }\end{array}$ & Unclear risk & Not reported \\
\hline $\begin{array}{l}\text { All outcomes } \\
\text { Incomplete outcome data (attrition bias) }\end{array}$ & High risk & Not reported \\
\hline \begin{tabular}{l} 
All outcomes \\
\hline
\end{tabular} & & $\%$ analysed: $72 \%(866 / 1200)$
\end{tabular}


Vogt 2003 (Continued)

\begin{tabular}{|c|c|c|}
\hline Selective reporting (reporting bias) & Unclear risk & $\begin{array}{l}\text { Insufficient information to permit judge- } \\
\text { ment }\end{array}$ \\
\hline Other bias & Unclear risk & $\begin{array}{l}\text { Insufficient information to assess whether } \\
\text { an important risk of bias exists }\end{array}$ \\
\hline
\end{tabular}

\section{Ward 1991}

\begin{tabular}{ll} 
Methods & Design - RCT \\
Baseline comparability - no significant differences between the study groups in terms of \\
factors studied \\
Follow-up - 1month \\
\hline
\end{tabular}

\begin{tabular}{|c|c|}
\hline Participants & $\begin{array}{l}\text { Country - Australia } \\
\text { Setting - General practice } \\
\text { Initial screening status - due } \\
204 \text { female patients of } 16 \text { GPs in the inner metropolitan region of Sydney } \\
\text { Inclusion criteria - women: aged } 20 \text { to } 65 \text { years; provided consent } \\
\text { physicians: provided consent; complied with study procedures } \\
\text { Exclusion criteria - women: pregnant; had smear in past year; attending for smear that } \\
\text { day; hysterectomy; never sexually active with male partner; insufficient command of } \\
\text { English to complete questionnaire } \\
\text { physicians: worked < } 20 \text { hrs/week; were on leave/sick leave at time or recruitment; were } \\
\text { expected to take leave during the study period; did not have the equipment to take smears }\end{array}$ \\
\hline Interventions & $\begin{array}{l}\text { 1. Minimal intervention: GP advised eligible women of need for smear and offered to } \\
\text { perform it immediately. Those not consenting advised to make appointment for smear } \\
\text { within a week } n=99 \\
\text { 2. Maximal intervention: GP advised woman of need for smear and offered to perform it } \\
\text { immediately; GP attempted to persuade those not consenting during that consultation } \\
\text { by exploring barriers and reasons for self-exclusions. If still did not consent, GP advised } \\
\text { making an appointment for smear within a week } n=103\end{array}$ \\
\hline
\end{tabular}

Pap smear uptake determined by administrative records

Fidelity of intervention implementation could not be checked; audiotapes were available for only a few consultations. One of the audiotapes recorded a time of 6 sec taken to give the maximal intervention (shortest time in minimal intervention was 10sec)

\section{Risk of bias}

\begin{tabular}{lll}
\hline Bias & Authors' judgement & Support for judgement \\
\hline $\begin{array}{l}\text { Random sequence generation (selection } \\
\text { bias) }\end{array}$ & Unclear risk & Not reported \\
\hline Allocation concealment (selection bias) & Unclear risk & Not reported
\end{tabular}




\section{Ward 1991 (Continued)}

\begin{tabular}{|c|c|c|}
\hline $\begin{array}{l}\text { Blinding (performance bias and detection } \\
\text { bias) } \\
\text { All outcomes }\end{array}$ & Unclear risk & Not reported \\
\hline $\begin{array}{l}\text { Incomplete outcome data (attrition bias) } \\
\text { All outcomes }\end{array}$ & Low risk & $\begin{array}{l}\text { \% analysed: } 91 \%(184 / 202) \\
\text { By treatment arm: } \\
\text { Minimal intervention: } 95 / 99(96 \%) \\
\text { Maximal intervention: 89/103 (86\%) }\end{array}$ \\
\hline Selective reporting (reporting bias) & Unclear risk & $\begin{array}{l}\text { Insufficient information to permit judge- } \\
\text { ment }\end{array}$ \\
\hline Other bias & Unclear risk & $\begin{array}{l}\text { Insufficient information to assess whether } \\
\text { an important risk of bias exists }\end{array}$ \\
\hline
\end{tabular}

Wilson 1987

\begin{tabular}{|c|c|c|}
\hline Methods & \multicolumn{2}{|c|}{$\begin{array}{l}\text { Design - RCT } \\
\text { Baseline comparability - no significant differences between the study groups in terms of } \\
\text { mean age } \\
\text { Follow-up - } 3 \text { weeks from final invitation letter }\end{array}$} \\
\hline Participants & \multicolumn{2}{|c|}{$\begin{array}{l}\text { Country - UK } \\
\text { Setting - National Screening Programme } \\
\text { Initial screening status - due, recorded as never having a smear } \\
250 \text { randomly selected women from five general practices ( } 50 \text { women per practice) in } \\
\text { the Nottingham Health Authority area } \\
\text { Inclusion criteria - aged } 45 \text { to } 65 \text { years; no record of having a previous smear } \\
\text { Exclusion criteria - hysterectomy or other medical condition }\end{array}$} \\
\hline Interventions & \multicolumn{2}{|c|}{$\begin{array}{l}\text { 1. Letter of invitation to make an appointment }+ \text { two reminders, } n=125 \\
\text { 2. Sent an appointment }+ \text { two reminders, } n=125\end{array}$} \\
\hline Outcomes & \multicolumn{2}{|c|}{ Pap smear uptake determined by administrative records } \\
\hline Notes & \multicolumn{2}{|c|}{$\begin{array}{l}\text { Only published as a letter. Final numbers of study participants is small compared to the } \\
\text { initial study population ( } 588 \text { women who fulfilled the study criteria were not included) }\end{array}$} \\
\hline \multicolumn{3}{|l|}{ Risk of bias } \\
\hline Bias & Authors' judgement & Support for judgement \\
\hline $\begin{array}{l}\text { Random sequence generation (selection } \\
\text { bias) }\end{array}$ & Unclear risk & Not reported \\
\hline Allocation concealment (selection bias) & Low risk & Centralised allocation was used \\
\hline
\end{tabular}


Wilson 1987 (Continued)

\begin{tabular}{|c|c|c|}
\hline $\begin{array}{l}\text { Blinding (performance bias and detection } \\
\text { bias) } \\
\text { All outcomes }\end{array}$ & Unclear risk & Not reported \\
\hline $\begin{array}{l}\text { Incomplete outcome data (attrition bias) } \\
\text { All outcomes }\end{array}$ & Low risk & $\begin{array}{l}\% \text { analysed: } 96 \%(240 / 250) \\
\text { By treatment arm: } \\
\text { Letter invitation: } 122 / 125(98 \%) \\
\text { Appointment: } 118 / 125(94 \%)\end{array}$ \\
\hline Selective reporting (reporting bias) & Unclear risk & $\begin{array}{l}\text { Insufficient information to permit judge- } \\
\text { ment }\end{array}$ \\
\hline Other bias & Unclear risk & $\begin{array}{l}\text { Insufficient information to assess whether } \\
\text { an important risk of bias exists }\end{array}$ \\
\hline
\end{tabular}

\section{Characteristics of excluded studies [ordered by study ID]}

\begin{tabular}{|c|c|}
\hline Study & Reason for exclusion \\
\hline Al Saifafi 2009 & Not RCT. Questionairre responses only. \\
\hline Baele 1998 & Quasi-RCT \\
\hline Boissel 1995 & Interventions targeted at General Practitioners rather than woman \\
\hline Bonevski 1999 & Interventions targeted at General Practitioners rather than woman \\
\hline Brewster 2002 & Comparisons of study recruitment strategies not of screening uptake \\
\hline Campbell 1997 & $\begin{array}{l}\text { Intervention aimed at both the participants and the physician and data does not allow effects of the two } \\
\text { components to be examined independently. Interventions aimed at physicians are excluded from this } \\
\text { review }\end{array}$ \\
\hline Cecchini 1989 & Interventions targeted at "promoting general practitioners' cooperation" and not at women \\
\hline Chumworathayi 2007 & Quasi-RCT \\
\hline Corkrey 2005 & $\begin{array}{l}\text { Number of uptake cases in each group is not reported. Increase uptake of } 0.43 \% \text { reported in intervention } \\
\text { group but no P-value or } 95 \% \mathrm{CI} \text { reported }\end{array}$ \\
\hline Del Mar 1995 & $\begin{array}{l}\text { Intervention more concerned with obtaining more up to date addresses for participants rather than strictly } \\
\text { increasing the uptake of screening }\end{array}$ \\
\hline
\end{tabular}


(Continued)

\begin{tabular}{|c|c|}
\hline Dignan 1996 & $\begin{array}{l}\text { Attendance for screening over the previous year was measured, but data were gathered only } 6 \text { months post } \\
\text { intervention. Therefore, it is unclear how the intervention affected uptake as participants may have been } \\
\text { screened prior to receiving the intervention }\end{array}$ \\
\hline Dignan 1998 & $\begin{array}{l}\text { Attendance for screening over the previous year was measured, but data were gathered only } 6 \text { months post } \\
\text { intervention. Therefore, it is unclear how the intervention affected uptake as participants may have been } \\
\text { screened prior to receiving the intervention }\end{array}$ \\
\hline Engelstad 2005 & Intervention aimed at improving follow-up following abnormal results rather than initial screening uptake \\
\hline German 1995 & $\begin{array}{l}\text { The study examines the effect of the intervention on the uptake of overall preventive visits and the data is } \\
\text { not specifically broken down into individual screening tests and procedures }\end{array}$ \\
\hline Gotay 2000 & $\begin{array}{l}\text { Outcome reported as "Ever had Pap test". This only captures new uptake rather than total uptake at follow } \\
\text { up }\end{array}$ \\
\hline Hancock 2001 & Not possible to extract relevant data for purposes of this review \\
\hline Hicks 1997 & Quasi-RCT \\
\hline Hillman 1998 & Interventions targeted at GP practices and not at women. \\
\hline Holloway 2003 & Outcomes reported at timing interval of smear uptake rather than number of women reporting uptake \\
\hline Hou 2002 & Quasi-RCT \\
\hline Hou 2005 & Quasi-RCT \\
\hline Jenkins 1999 & Not an RCT \\
\hline Karwalajtys 2007 & Not RCT \\
\hline Katz 2007 & Intervention was aimed at increasing mammography uptake \\
\hline Lam 2003 & Initial data only. Full data included in Mock 2007. \\
\hline Lantz 1995 & Quasi-RCT \\
\hline Lantz 1996 & Quasi-RCT \\
\hline Lauver 1990 & Intervention aimed at improving follow-up following abnormal results rather than initial screening uptake \\
\hline Levine 2003 & Quasi-RCT \\
\hline Litzelman 1993 & Interventions targeted at physicians to improve uptake and not at women \\
\hline
\end{tabular}


(Continued)

\begin{tabular}{ll} 
Lynch 2004 & $\begin{array}{l}\text { Cost effectiveness study. Data reported as uptake of both cervical screening and mammography and not } \\
\text { reported separately }\end{array}$ \\
\hline Manfredi 1998 & Interventions targeted at physicians to improve uptake and not at women \\
\hline Marcus 1992 & Cluster quasi-RCT \\
\hline Marcus 1998 & Intervention aimed at improving follow-up following abnormal results rather than initial screening uptake \\
\hline Margolis 1998 & Quasi-RCT \\
\hline
\end{tabular}

Maxwell 2003 Quasi-RCT. “....[women] wanted to attend the same group session, 5-10 women were randomised to one study condition and the next group of 5-10 women to the other."

\begin{tabular}{|c|c|}
\hline Mayer 1992 & $\begin{array}{l}\text { Age range is } 65 \text { years and older and therefore does not represent the generally accepted age group for cervical } \\
\text { screening programmes }\end{array}$ \\
\hline Miller 1999 & Intervention aimed at improving follow-up following abnormal results rather than initial screening uptake \\
\hline Miller 2007 & Not RCT. Qualitative study \\
\hline Mitchell 1991 & $\begin{array}{l}\text { Not an RCT: The educational campaign was not randomly assigned and } 2000 \text { women were only randomly } \\
\text { selected within each of the campaign study groups to receive the personal invitation letter }\end{array}$ \\
\hline Mitchell 1997 & Not RCT \\
\hline Newell 2002 & RCT. However data is not presented in a way that is interpretable for purposes of the review \\
\hline Nguyen 2000 & Interventions targeted at physicians to improve uptake and not at women \\
\hline Park 2005 & LIkely Quasi-RCT. “...randomly assigned to the experimental or control group in order of contact...” \\
\hline Paskett 1990 & Quasi-RCT \\
\hline Paskett 1995 & Intervention aimed at improving follow-up following abnormal results rather than initial screening uptake \\
\hline Paskett 1999 & Not RCT. “..mixed cohort/cross-sectional design.” \\
\hline Paul 2003 & Outcome was enrolment to Pap smear reminder service \\
\hline Perkins 2007 & Not RCT. Cross-sectional study. \\
\hline Peters 1999 & $\begin{array}{l}\text { Cluster RCT examining anxiety among women with mild dyskaryosis and the aim of the educational } \\
\text { intervention was to reduce anxiety so scope differs to that of this review }\end{array}$ \\
\hline Philips 2006 & Outcome is "willingness to pay" rather than screening uptake \\
\hline
\end{tabular}


(Continued)

\begin{tabular}{|c|c|}
\hline Powers 1992 & $\begin{array}{l}\text { Study examined attendance for a number of screening tests and did not separate data according to the type } \\
\text { of test }\end{array}$ \\
\hline Roetzheim 2004 & Interventions targeted at clinic staff and not at women. \\
\hline Roetzheim 2005 & Interventions targeted at attempting "to change systematically the behaviours of all office staff" \\
\hline Ruffin 2004 & $\begin{array}{l}\text { Age range is } 50 \text { years and older and therefore does not represent a majority of the generally accepted age } \\
\text { group for cervical screening programmes } \\
\text { Loss to follow up was reported by practice, but not in terms of numbers of recruits or treatments arms } \\
\text { Percentage uptake rates of } 2 \text { and } 3 \text { year follow up does not use baseline as a reference point }\end{array}$ \\
\hline Sankaranarayanan 2003 & Outcome is "effectiveness of VIA screening" not uptake of screening \\
\hline Shelley 1991 & Not RCT \\
\hline Stewart 1994 & Intervention aimed at improving follow-up following abnormal results rather than initial screening uptake \\
\hline Takacs 2004 & Intervention aimed at improving follow-up following abnormal results rather than initial screening uptake \\
\hline Tomlinson 2004 & Intervention aimed at improving follow-up following abnormal results rather than initial screening uptake \\
\hline Torres-Mejia 2000 & Recruits were "systematically assigned." Not RCT \\
\hline Valanis 2003 & $\begin{array}{l}\text { Age range is } 50-69 \text { years and therefore does not represent a majority of the generally accepted age group } \\
\text { for cervical screening programmes }\end{array}$ \\
\hline Ward 1999 & Quasi-RCT \\
\hline Yancey 1995 & Quasi-RCT \\
\hline
\end{tabular}


DATA AND ANALYSES

Comparison 1. Invitation vs control

\begin{tabular}{|c|c|c|c|c|}
\hline Outcome or subgroup title & $\begin{array}{l}\text { No. of } \\
\text { studies }\end{array}$ & $\begin{array}{c}\text { No. of } \\
\text { participants }\end{array}$ & Statistical method & Effect size \\
\hline 1 Uptake of screening & 15 & 105881 & Risk Ratio (IV, Random, 95\% CI) & $1.65[1.44,1.90]$ \\
\hline 1.1 Invitation letter vs control & 12 & 99651 & Risk Ratio (IV, Random, 95\% CI) & $1.44[1.24,1.67]$ \\
\hline $\begin{array}{l}1.2 \text { Telephone invitation vs } \\
\text { control }\end{array}$ & 4 & 2342 & Risk Ratio (IV, Random, 95\% CI) & $2.16[1.70,2.74]$ \\
\hline $\begin{array}{l}1.3 \text { Face to face invitation vs } \\
\text { control }\end{array}$ & 1 & 121 & Risk Ratio (IV, Random, 95\% CI) & $9.15[0.50,166.30]$ \\
\hline $\begin{array}{l}1.4 \text { Letter with open invitation } \\
\text { to make appointment vs } \\
\text { control }\end{array}$ & 4 & 2998 & Risk Ratio (IV, Random, 95\% CI) & $1.61[1.15,2.26]$ \\
\hline $\begin{array}{l}\text { 1.5 Letter with fixed } \\
\text { appointment vs control }\end{array}$ & 1 & 177 & Risk Ratio (IV, Random, 95\% CI) & $1.80[1.04,3.11]$ \\
\hline $\begin{array}{l}\text { 1.6 Letter invitation with } \\
\text { telephone follow up vs control }\end{array}$ & 1 & 276 & Risk Ratio (IV, Random, 95\% CI) & $3.14[1.97,5.01]$ \\
\hline $\begin{array}{l}1.7 \text { Celebrity letter invitation } \\
\text { vs control }\end{array}$ & 1 & 316 & Risk Ratio (IV, Random, 95\% CI) & $2.15[0.25,18.15]$ \\
\hline
\end{tabular}

Comparison 2. GP invitation letter vs invitation letter from other authority sources

\begin{tabular}{|c|c|c|c|c|}
\hline Outcome or subgroup title & $\begin{array}{l}\text { No. of } \\
\text { studies }\end{array}$ & $\begin{array}{c}\text { No. of } \\
\text { participants }\end{array}$ & Statistical method & Effect size \\
\hline 1 Uptake of screening & 2 & & Risk Ratio (IV, Random, 95\% CI) & Totals not selected \\
\hline $\begin{array}{l}\text { 1.1 GP invitation letter vs } \\
\text { health clinic invitation letter }\end{array}$ & 1 & & Risk Ratio (IV, Random, 95\% CI) & $0.0[0.0,0.0]$ \\
\hline $\begin{array}{l}\text { 1.2 GP invitation letter } \\
\text { vs invitation letter from } \\
\text { programme coordinator }\end{array}$ & 1 & & Risk Ratio (IV, Random, 95\% CI) & $0.0[0.0,0.0]$ \\
\hline
\end{tabular}


Comparison 3. Personal invitation vs invitation letter

\begin{tabular}{lcccc} 
Outcome or subgroup title & $\begin{array}{c}\text { No. of } \\
\text { studies }\end{array}$ & $\begin{array}{c}\text { No. of } \\
\text { participants }\end{array}$ & Statistical method & Effect size \\
\hline $\begin{array}{l}1 \text { Uptake of screening } \\
\quad 1.1 \text { Telephone invitation vs }\end{array}$ & 2 & 1899 & $\begin{array}{l}\text { Risk Ratio (IV, Random, 95\% CI) } \\
\text { Risk Ratio (IV, Random, 95\% CI) }\end{array}$ & $\begin{array}{l}\text { Subtotals only } \\
\text { invitation letter } \\
\quad \begin{array}{l}1.2 \text { Face-to-face invitation vs } \\
\text { invitation letter }\end{array}\end{array}$ \\
\hline
\end{tabular}

Comparison 4. Letter with fixed appointment vs letter with open invitation to make an appointment

\begin{tabular}{lcccc} 
Outcome or subgroup title & $\begin{array}{c}\text { No. of } \\
\text { studies }\end{array}$ & $\begin{array}{c}\text { No. of } \\
\text { participants }\end{array}$ & Statistical method & Effect size \\
\hline 1 Uptake of screening & 4 & 4706 & Risk Ratio (IV, Random, 95\% CI) & $1.57[1.43,1.72]$ \\
\hline
\end{tabular}

Comparison 5. Education vs control

\begin{tabular}{|c|c|c|c|c|}
\hline Outcome or subgroup title & $\begin{array}{l}\text { No. of } \\
\text { studies }\end{array}$ & $\begin{array}{c}\text { No. of } \\
\text { participants }\end{array}$ & Statistical method & Effect size \\
\hline 1 Uptake of screening & 6 & & Risk Ratio (IV, Random, 95\% CI) & Subtotals only \\
\hline $\begin{array}{l}1.1 \text { Education (printed } \\
\text { material) vs control }\end{array}$ & 3 & 502 & Risk Ratio (IV, Random, 95\% CI) & $1.11[0.88,1.41]$ \\
\hline $\begin{array}{l}1.2 \text { Education (miscellaneous) } \\
\text { vs control }\end{array}$ & 2 & 295 & Risk Ratio (IV, Random, 95\% CI) & $1.92[1.24,2.97]$ \\
\hline $\begin{array}{l}1.3 \text { Education (face-to-face } \\
\text { home visits) vs control }\end{array}$ & 3 & 1318 & Risk Ratio (IV, Random, 95\% CI) & $2.33[1.04,5.23]$ \\
\hline
\end{tabular}

Comparison 6. Education vs other

\begin{tabular}{|c|c|c|c|c|}
\hline Outcome or subgroup title & $\begin{array}{l}\text { No. of } \\
\text { studies }\end{array}$ & $\begin{array}{c}\text { No. of } \\
\text { participants }\end{array}$ & Statistical method & Effect size \\
\hline 1 Uptake of screening & 4 & & Risk Ratio (IV, Random, 95\% CI) & Totals not selected \\
\hline $\begin{array}{l}1.1 \text { Education (printed } \\
\text { material) vs health clinic } \\
\text { invitation letter }\end{array}$ & 1 & & Risk Ratio (IV, Random, 95\% CI) & $0.0[0.0,0.0]$ \\
\hline $\begin{array}{l}1.2 \text { Education (printed } \\
\text { material) vs GP invitation letter }\end{array}$ & 1 & & Risk Ratio (IV, Random, 95\% CI) & $0.0[0.0,0.0]$ \\
\hline
\end{tabular}


1.3 Education (format unknown) vs enhanced risk assessment

1.4 Education (printed material) vs education (video/slide)

1.5 Intensive peer health advice vs other

2 Lay health outreach worker and media education vs media education

3 Standard invitation and printed education vs standard invitation

\section{Comparison 7. Counselling vs control}

\begin{tabular}{lcccc} 
Outcome or subgroup title & $\begin{array}{c}\text { No. of } \\
\text { studies }\end{array}$ & $\begin{array}{c}\text { No. of } \\
\text { participants }\end{array}$ & Statistical method & Effect size \\
\hline $\begin{array}{l}\text { 1 Uptake of screening } \\
\quad 2\end{array}$ & 393 & Risk Ratio (IV, Random, 95\% CI) & $1.23[1.04,1.45]$ \\
$\begin{array}{l}1.1 \text { Face-to-face counselling vs } \\
\text { control }\end{array}$ & 1 & 184 & Risk Ratio (IV, Random, 95\% CI) & $1.23[0.98,1.55]$ \\
$\quad \begin{array}{l}1.2 \text { Telephone counselling vs } \\
\text { control }\end{array}$ & 1 & 209 & Risk Ratio (IV, Random, 95\% CI) & $1.22[0.97,1.55]$ \\
\hline
\end{tabular}

Comparison 8. Counselling vs other

\begin{tabular}{|c|c|c|c|c|}
\hline Outcome or subgroup title & $\begin{array}{l}\text { No. of } \\
\text { studies }\end{array}$ & $\begin{array}{l}\text { No. of } \\
\text { participants }\end{array}$ & Statistical method & Effect size \\
\hline 1 Uptake of screening & 1 & & Risk Ratio (IV, Random, 95\% CI) & Totals not selected \\
\hline $\begin{array}{l}1.1 \text { Telephone counselling vs } \\
\text { provider prompts }\end{array}$ & 1 & & Risk Ratio (IV, Random, 95\% CI) & $0.0[0.0,0.0]$ \\
\hline
\end{tabular}


Comparison 9. Enhanced risk assessment vs control

\begin{tabular}{lcccc} 
Outcome or subgroup title & $\begin{array}{c}\text { No. of } \\
\text { studies }\end{array}$ & $\begin{array}{c}\text { No. of } \\
\text { participants }\end{array}$ & Statistical method & Effect size \\
\hline 1 Uptake of screening & 2 & 145 & Risk Ratio (IV, Random, 95\% CI) & $1.52[0.58,3.95]$ \\
\hline
\end{tabular}

Comparison 10. Enhanced risk assessment vs other

\begin{tabular}{lcccc} 
Outcome or subgroup title & $\begin{array}{c}\text { No. of } \\
\text { studies }\end{array}$ & $\begin{array}{c}\text { No. of } \\
\text { participants }\end{array}$ & Statistical method & Effect size \\
\hline 1 Uptake of screening & 1 & & Risk Ratio (IV, Random, 95\% CI) & Totals not selected \\
\hline
\end{tabular}

Comparison 11. Access to health promotion nurse vs control

\begin{tabular}{|c|c|c|c|c|}
\hline Outcome or subgroup title & $\begin{array}{l}\text { No. of } \\
\text { studies }\end{array}$ & $\begin{array}{c}\text { No. of } \\
\text { participants }\end{array}$ & Statistical method & Effect size \\
\hline 1 Uptake of screening & 1 & & Risk Ratio (IV, Random, 95\% CI) & Subtotals only \\
\hline
\end{tabular}

Comparison 12. Photocomic vs placebo comic

\begin{tabular}{|c|c|c|c|c|}
\hline Outcome or subgroup title & $\begin{array}{l}\text { No. of } \\
\text { studies }\end{array}$ & $\begin{array}{c}\text { No. of } \\
\text { participants }\end{array}$ & Statistical method & Effect size \\
\hline 1 Uptake of screening & 1 & & Risk Ratio (IV, Random, 95\% CI) & Subtotals only \\
\hline
\end{tabular}

Comparison 13. Intensive recruitment attempts vs control

\begin{tabular}{|c|c|c|c|c|}
\hline Outcome or subgroup title & $\begin{array}{l}\text { No. of } \\
\text { studies }\end{array}$ & $\begin{array}{c}\text { No. of } \\
\text { participants }\end{array}$ & Statistical method & Effect size \\
\hline 1 Uptake of screening & 1 & & Risk Ratio (IV, Random, 95\% CI) & Subtotals only \\
\hline
\end{tabular}




\begin{tabular}{|c|c|c|c|c|}
\hline Outcome or subgroup title & $\begin{array}{l}\text { No. of } \\
\text { studies }\end{array}$ & $\begin{array}{c}\text { No. of } \\
\text { participants }\end{array}$ & Statistical method & Effect size \\
\hline $\begin{array}{l}1 \text { Gain versus loss message framing } \\
\text { (Detection) }\end{array}$ & 1 & & Risk Ratio (IV, Random, 95\% CI) & Subtotals only \\
\hline $\begin{array}{l}2 \text { Gain versus loss message framing } \\
\text { (Prevention) }\end{array}$ & 1 & & Risk Ratio (IV, Random, 95\% CI) & Subtotals only \\
\hline $\begin{array}{l}3 \text { Gain Message Framing: } \\
\text { Prevention vs Detection }\end{array}$ & 1 & & Risk Ratio (IV, Random, 95\% CI) & Subtotals only \\
\hline $\begin{array}{l}4 \text { Loss Message Framing: } \\
\text { Prevention vs Detection }\end{array}$ & 1 & & Risk Ratio (IV, Random, 95\% CI) & Subtotals only \\
\hline
\end{tabular}

\section{Analysis I.I. Comparison I Invitation vs control, Outcome I Uptake of screening.}

Review: Interventions targeted at women to encourage the uptake of cervical screening

Comparison: I Invitation vs control

Outcome: I Uptake of screening

\begin{tabular}{|c|c|c|c|c|c|c|c|}
\hline \multirow[t]{2}{*}{ Study or subgroup } & Invitation & Control & \multicolumn{3}{|r|}{ Risk Ratio } & Weight & Risk Ratio \\
\hline & $\mathrm{n} / \mathrm{N}$ & $\mathrm{n} / \mathrm{N}$ & \multicolumn{3}{|c|}{ IV,Random,95\% Cl } & & IV,Random,95\% Cl \\
\hline \multicolumn{8}{|l|}{ I Invitation letter vs control } \\
\hline Binstock 1997 & $202 / 763$ & $125 / 763$ & & & 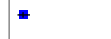 & $7.5 \%$ & $1.62[1.32,1.97]$ \\
\hline Bowman 1995 & $13 / 45$ & $9 / 52$ & & & + & $2.4 \%$ & $1.67[0.79,3.53]$ \\
\hline Buehler 1997 & $19 / 178$ & $13 / 208$ & & & - & $2.8 \%$ & I.7| $[0.87,3.36]$ \\
\hline Burack 1998 & $280 / 964$ & $270 / 964$ & & & 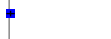 & $8.2 \%$ & $1.04[0.90,1.19]$ \\
\hline Burack 2003 & $371 / 1243$ & $284 / 1228$ & & & - & $8.3 \%$ & $1.29[1.13,1.47]$ \\
\hline Del Mar 1998 & $36 / 359$ & $39 / 330$ & & & + & $4.8 \%$ & $0.85[0.55,1.30]$ \\
\hline Hunt 1998 & $2 / 63$ & $0 / 61$ & & & & $0.2 \%$ & $4.84[0.24,98.88]$ \\
\hline Lancaster 1992 & $151 / 908$ & $89 / 886$ & & & 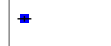 & $7.0 \%$ & $1.66[1.30,2.12]$ \\
\hline McDowell 1989 & $38 / 184$ & $18 / 165$ & & & + & $3.9 \%$ & $1.89[1.13,3.18]$ \\
\hline Morrell 2005 & $2630 / 59780$ & $868 / 29919$ & & & - & $8.7 \%$ & $1.52[1.41,1.64]$ \\
\hline Pierce 1989 & $45 / 140$ & $20 / 134$ & & & + & $4.3 \%$ & $2.15[1.35,3.45]$ \\
\hline Stein 2005 & $13 / 219$ & ।/95 & & & & $0.4 \%$ & $5.64[0.75,42.50]$ \\
\hline \multirow[t]{3}{*}{ Subtotal (95\% CI) } & 64846 & 34805 & & & - & $58.5 \%$ & $1.44[1.24,1.67]$ \\
\hline & & & 0.01 & 0.1 & 10 & 100 & \\
\hline & & & Favour & Contr & Favours & vitation & \\
\hline
\end{tabular}




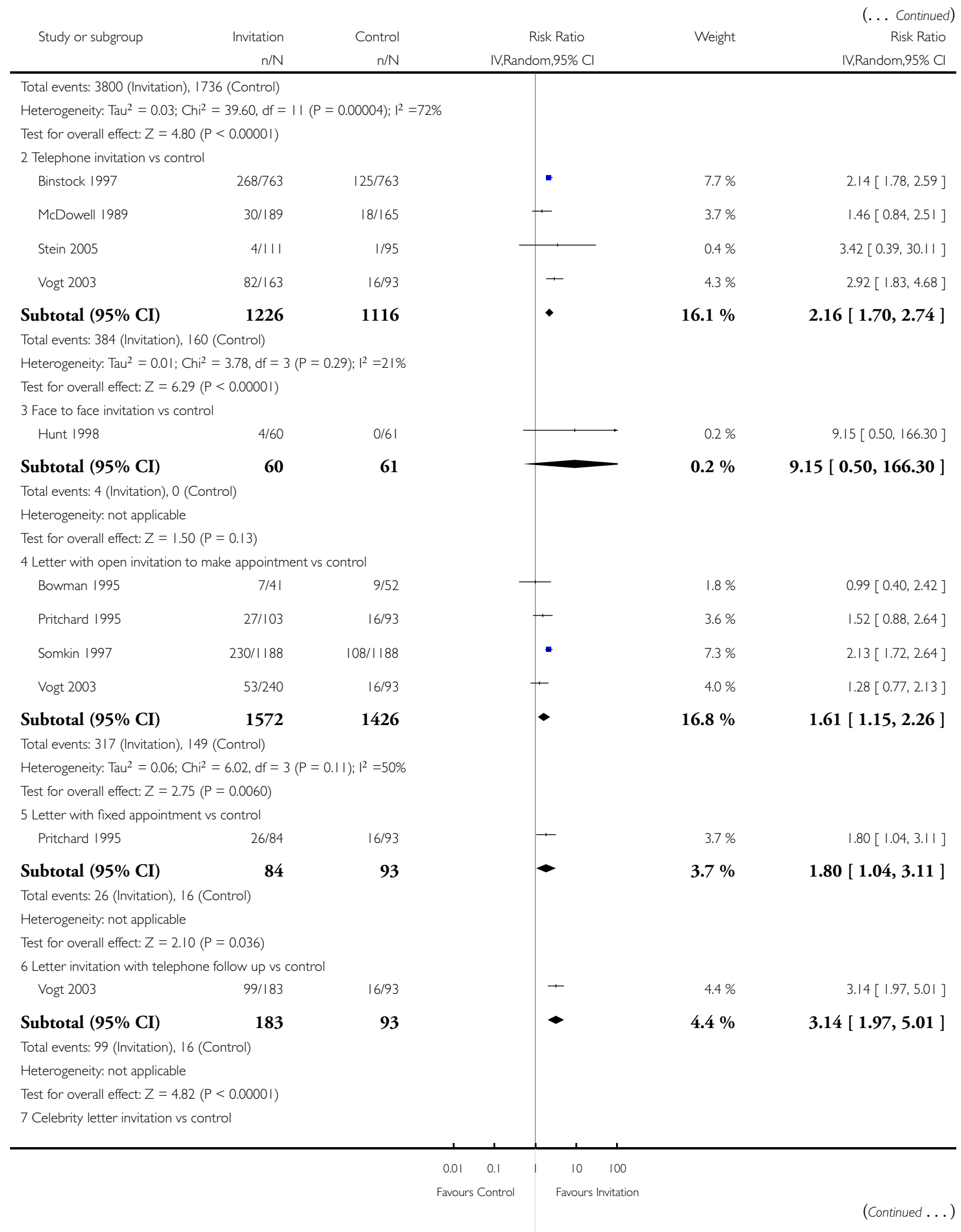




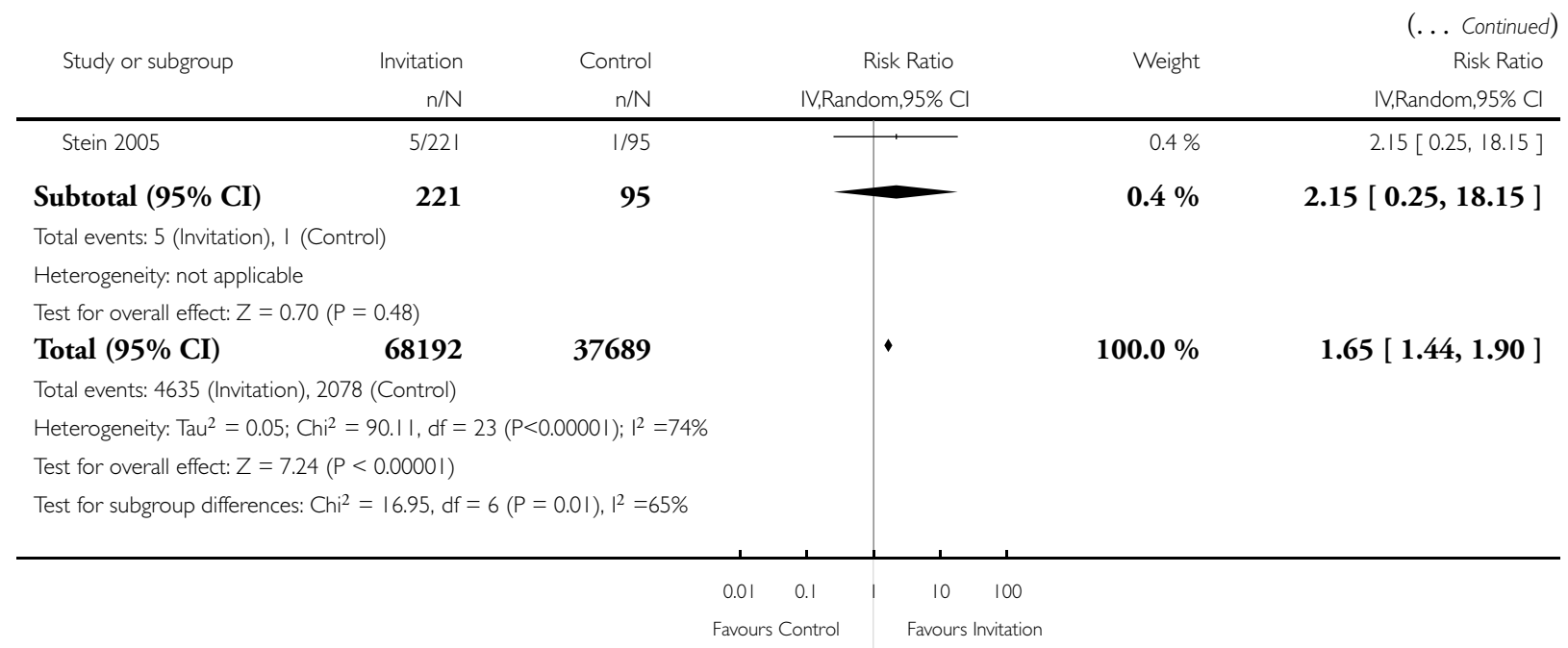

\section{Analysis 2.1. Comparison 2 GP invitation letter vs invitation letter from other authority sources, Outcome I Uptake of screening.}

Review: Interventions targeted at women to encourage the uptake of cervical screening

Comparison: 2 GP invitation letter vs invitation letter from other authority sources

Outcome: I Uptake of screening

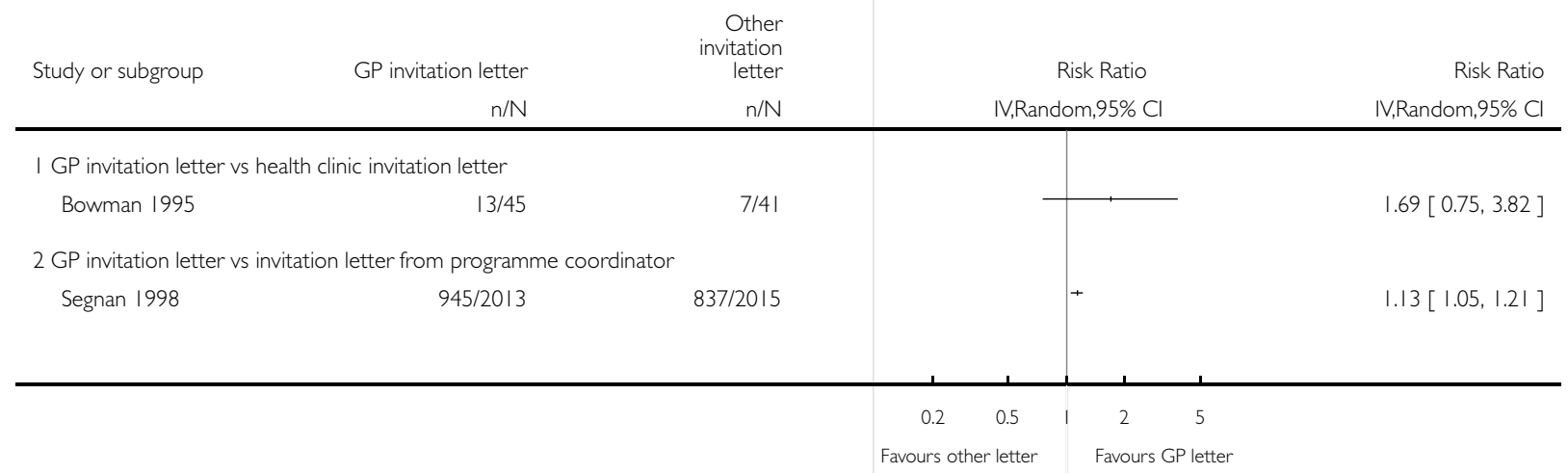


Analysis 3.I. Comparison 3 Personal invitation vs invitation letter, Outcome I Uptake of screening.

Review: Interventions targeted at women to encourage the uptake of cervical screening

Comparison: 3 Personal invitation vs invitation letter

Outcome: I Uptake of screening

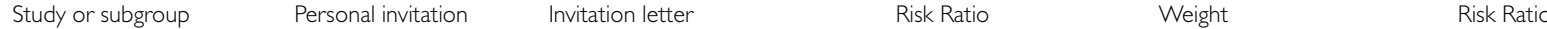

$\mathrm{n} / \mathrm{N} \quad \mathrm{n} / \mathrm{N} \quad$ IV,Random,95\% Cl IV,Random,95\% Cl

I Telephone invitation vs invitation letter

Binstock $1997 \quad 268 / 763 \quad 202 / 763$

McDowell $1989 \quad 38 / 184 \quad 30 / 18$

Subtotal (95\% CI)

$947 \quad 952$

\begin{tabular}{l|l} 
& \\
7 & $+763 \%$
\end{tabular}

Total events: 306 (Personal invitation), 232 (Invitation letter)

Heterogeneity: $\operatorname{Tau}^{2}=0.0 ; \mathrm{Chi}^{2}=0.0 \mathrm{I}, \mathrm{df}=\mathrm{I}(\mathrm{P}=0.93) ; \mathrm{I}^{2}=0.0 \%$

Test for overall effect: $Z=3.82(P=0.00013)$

2 Face-to-face invitation vs invitation letter

Hunt 1998

$4 / 60$

$2 / 63$

60

63

Subtotal (95\% CI)

letter)

Total events: 4 (Personal invitati
Heterogeneity: not applicable

Test for overall effect: $Z=0.88(P=0.38)$

$11.0 \%$

$100.0 \%$

$\checkmark$

$1.32[1.15,1.53]$

$1.30[0.84,2.01]$
$1.33[1.14,1.55]$

$100.0 \%$

$2.10[0.40,11.05]$

$100.0 \% \quad 2.10[0.40,11.05]$ 
Analysis 4.I. Comparison 4 Letter with fixed appointment vs letter with open invitation to make an appointment, Outcome I Uptake of screening.

Review: Interventions targeted at women to encourage the uptake of cervical screening

Comparison: 4 Letter with fixed appointment vs letter with open invitation to make an appointment

Outcome: I Uptake of screening

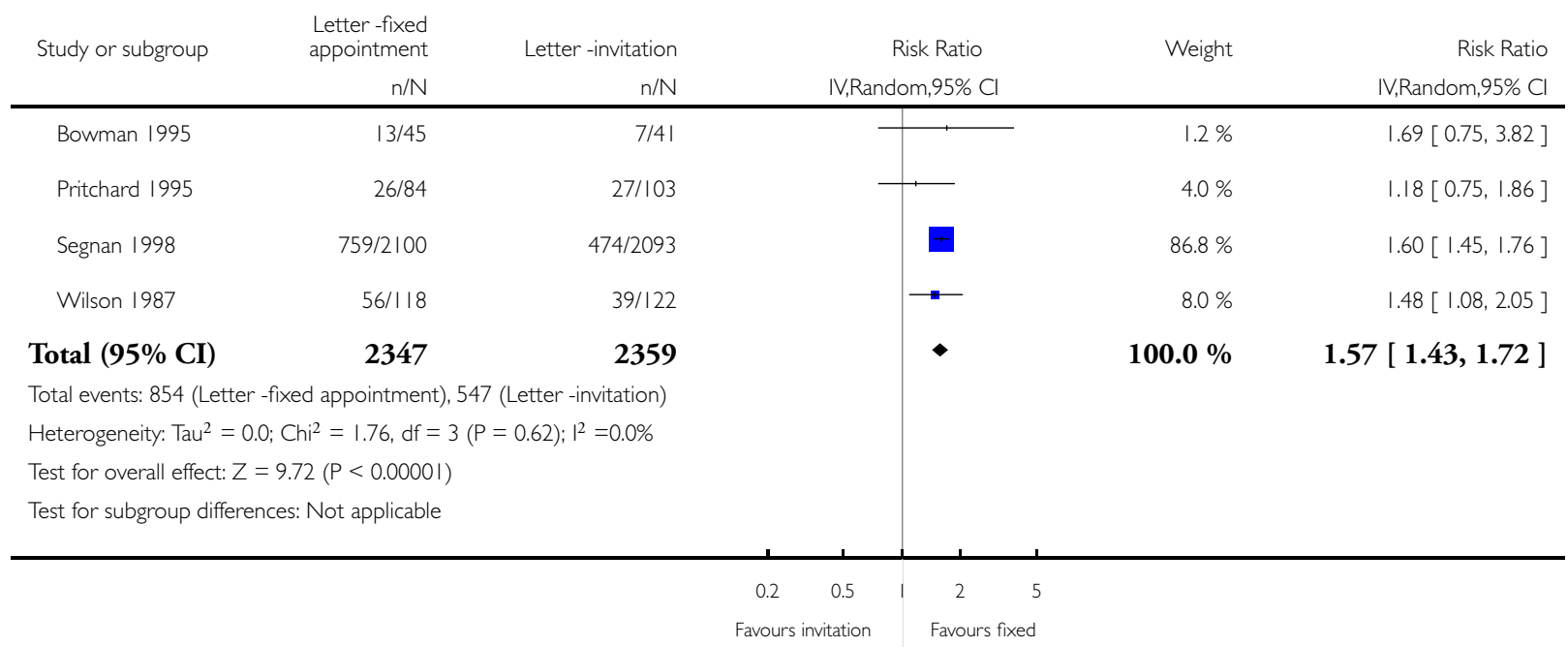




\section{Analysis 5.I. Comparison 5 Education vs control, Outcome I Uptake of screening.}

Review: Interventions targeted at women to encourage the uptake of cervical screening

Comparison: 5 Education vs control

Outcome: I Uptake of screening

Study or subgroup Education Control Risk Ratio Weight

$\mathrm{n} / \mathrm{N} \quad \mathrm{n} / \mathrm{N} \quad$ IV,Random, $95 \% \mathrm{Cl}$ IVandom,95\% Cl

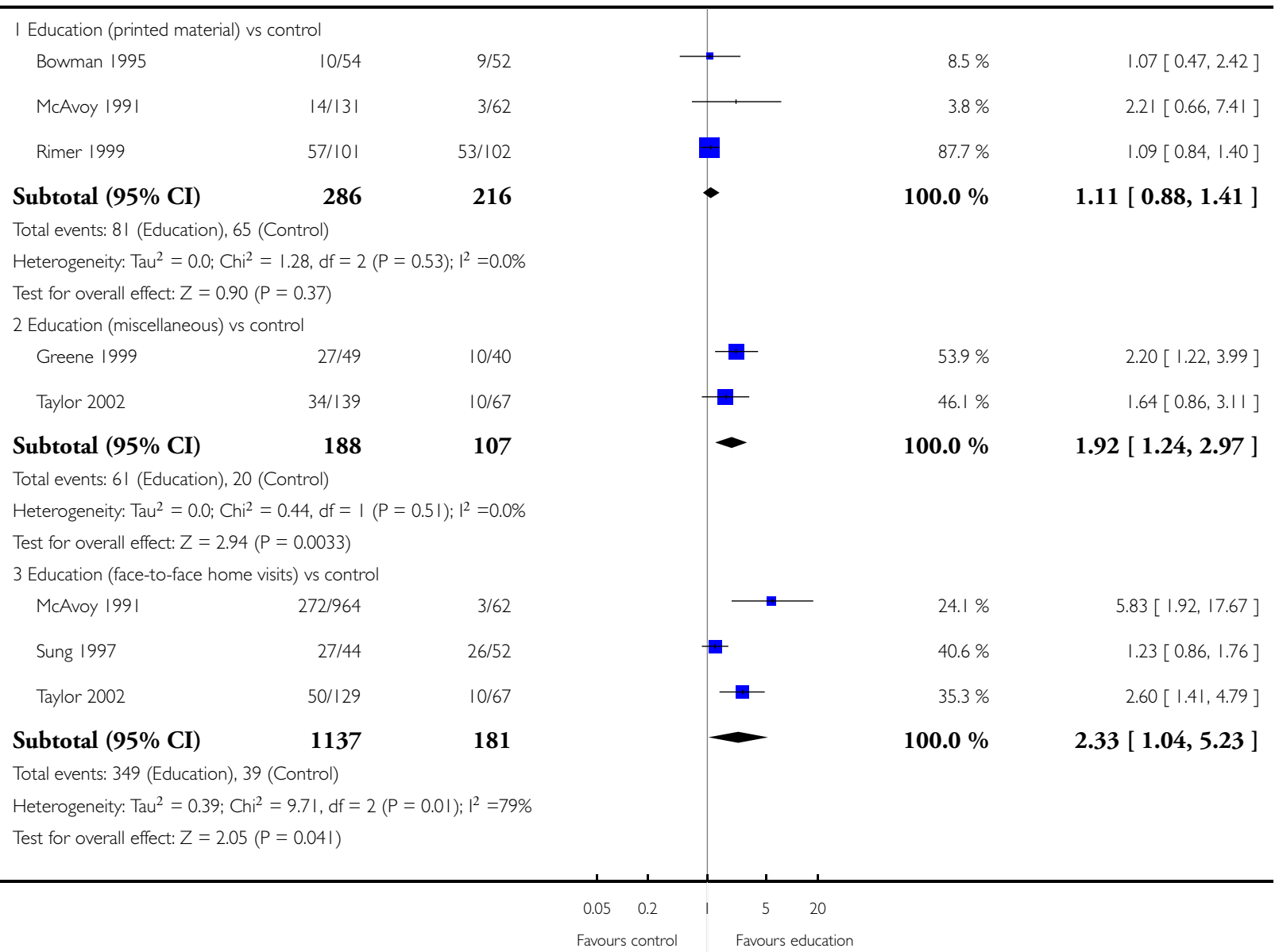




\section{Analysis 6.I. Comparison 6 Education vs other, Outcome I Uptake of screening.}

Review: Interventions targeted at women to encourage the uptake of cervical screening

Comparison: 6 Education vs other

Outcome: I Uptake of screening

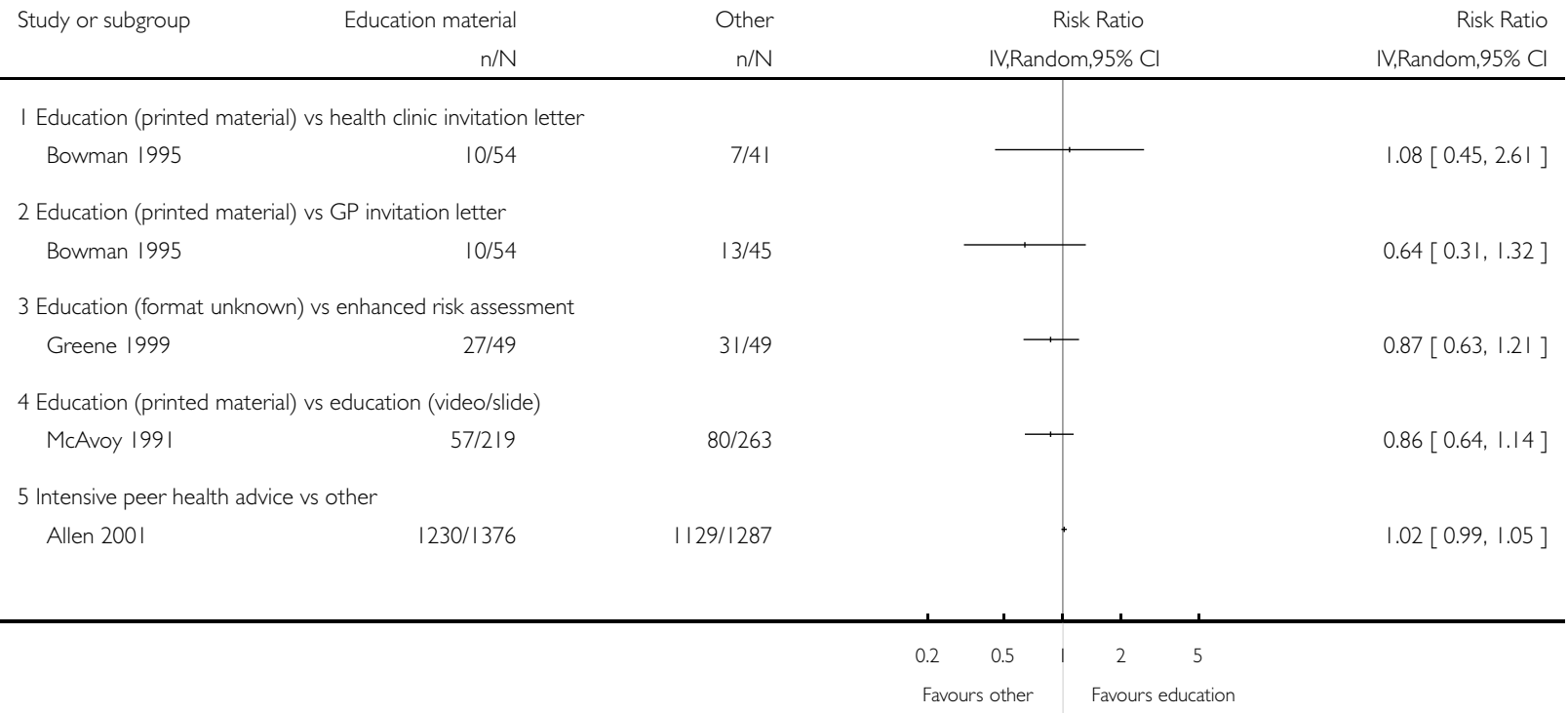

\section{Analysis 6.2. Comparison 6 Education vs other, Outcome 2 Lay health outreach worker and media} education vs media education.

Review: Interventions targeted at women to encourage the uptake of cervical screening

Comparison: 6 Education vs other

Outcome: 2 Lay health outreach worker and media education vs media education

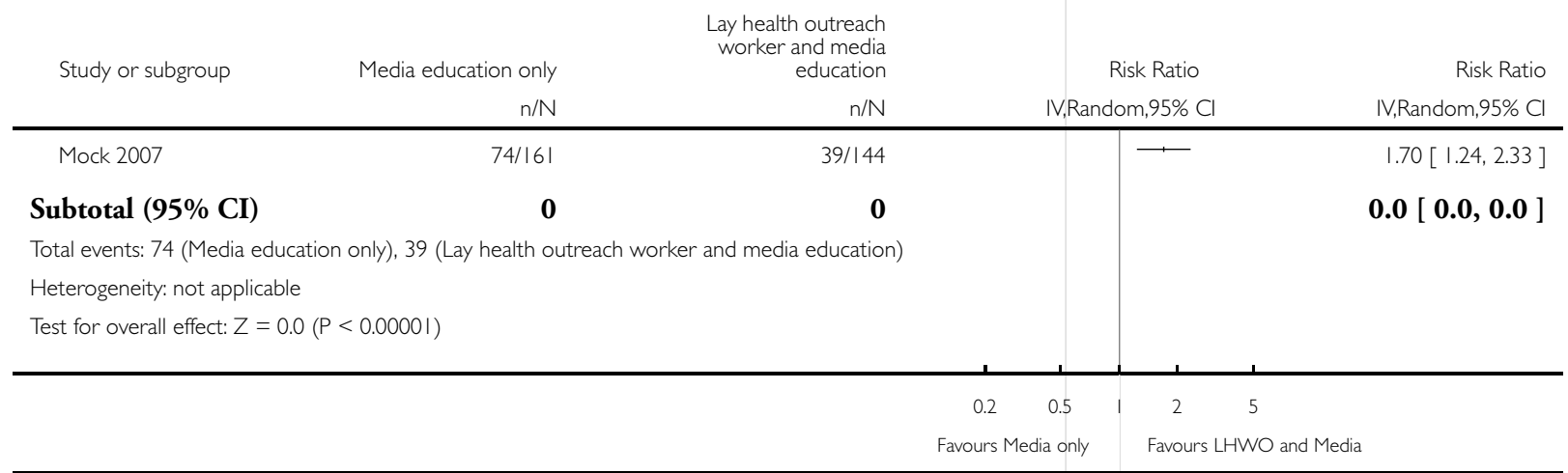




\section{Analysis 6.3. Comparison 6 Education vs other, Outcome 3 Standard invitation and printed education vs}

standard invitation.

Review: Interventions targeted at women to encourage the uptake of cervical screening

Comparison: 6 Education vs other

Outcome: 3 Standard invitation and printed education vs standard invitation

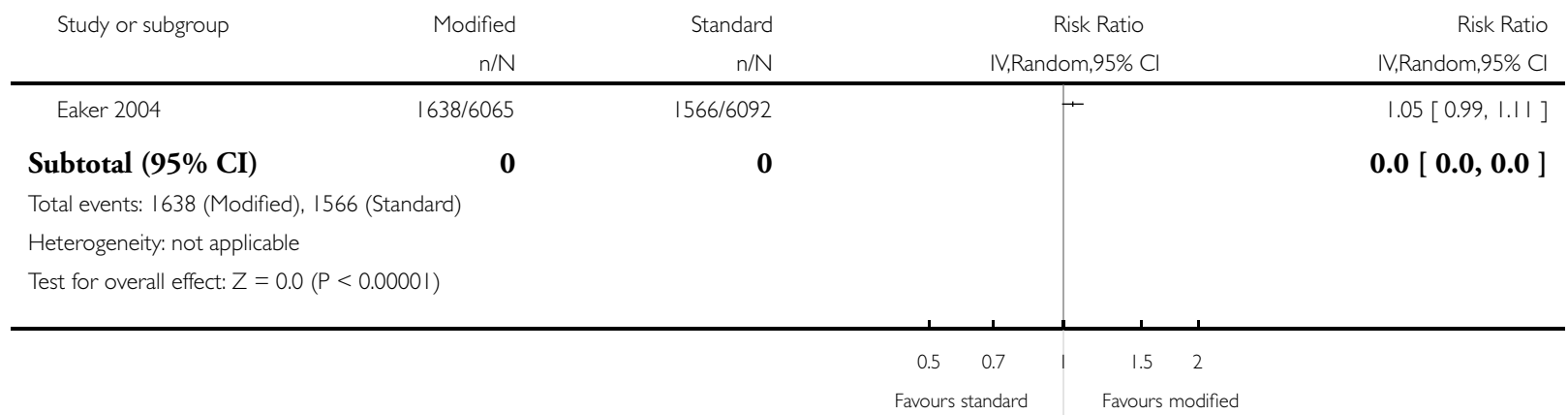




\section{Analysis 7.I. Comparison 7 Counselling vs control, Outcome I Uptake of screening.}

Review: Interventions targeted at women to encourage the uptake of cervical screening

Comparison: 7 Counselling vs control

Outcome: I Uptake of screening

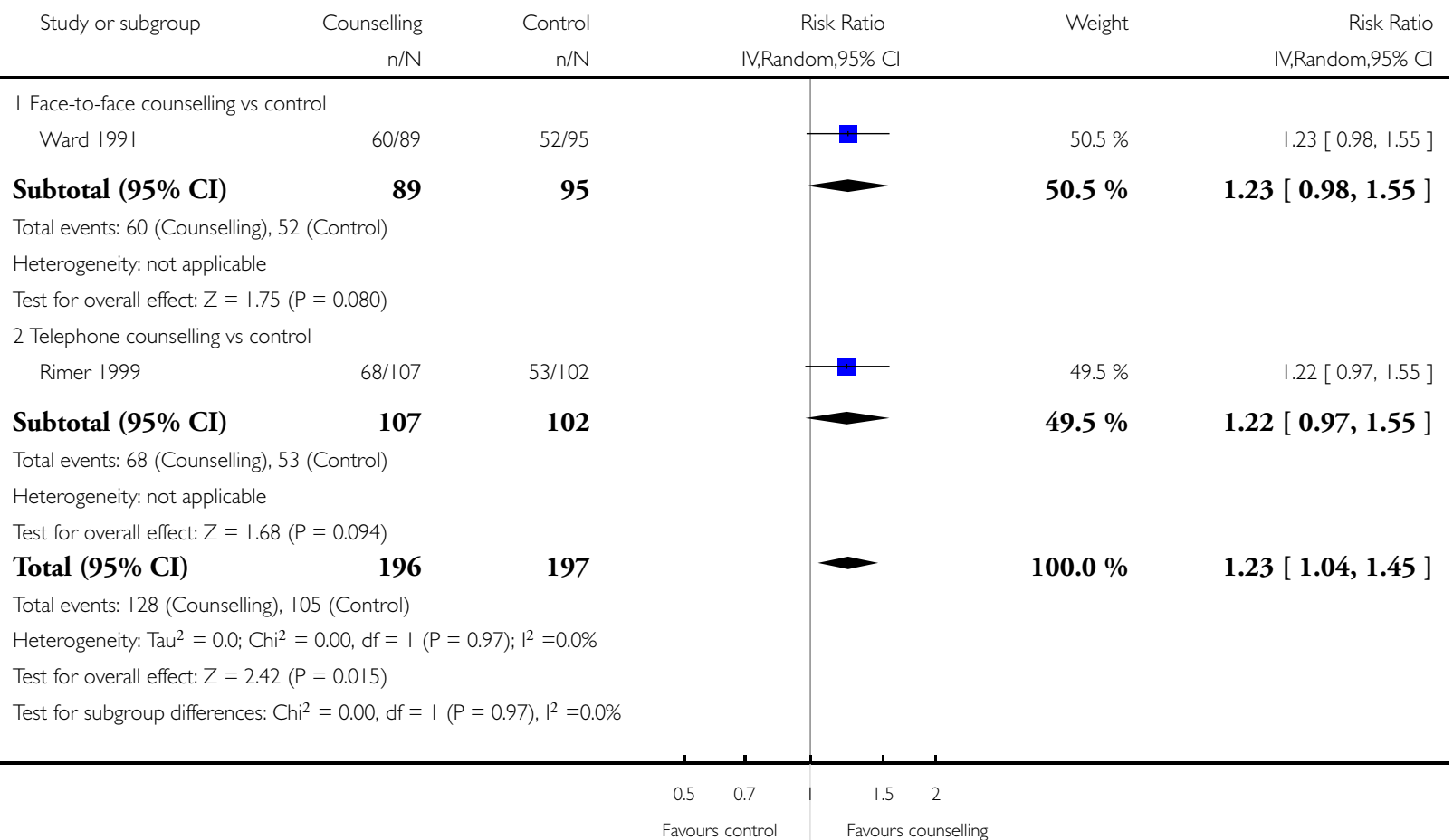

Analysis 8.I. Comparison 8 Counselling vs other, Outcome I Uptake of screening.

Review: Interventions targeted at women to encourage the uptake of cervical screening

Comparison: 8 Counselling vs other

Outcome: I Uptake of screening

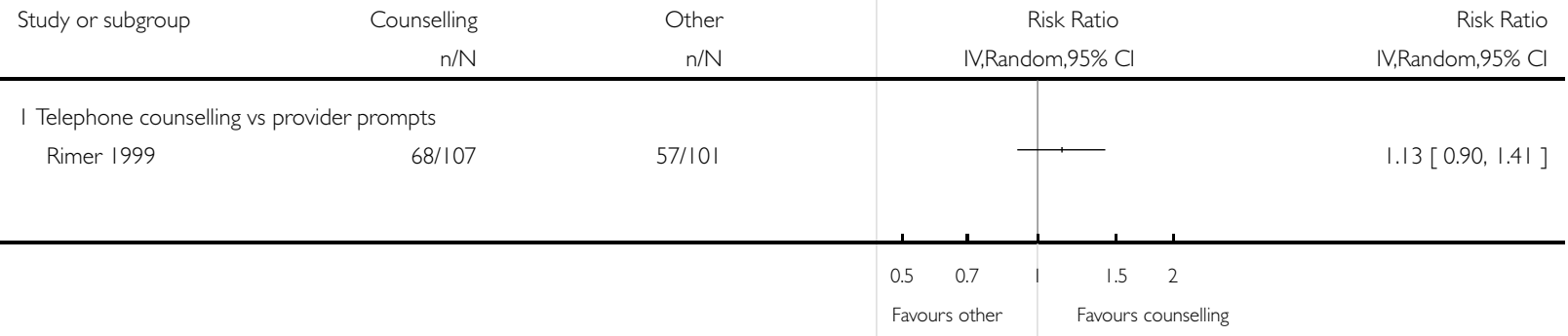


Analysis 9.1. Comparison 9 Enhanced risk assessment vs control, Outcome I Uptake of screening.

Review: Interventions targeted at women to encourage the uptake of cervical screening

Comparison: 9 Enhanced risk assessment vs control

Outcome: I Uptake of screening

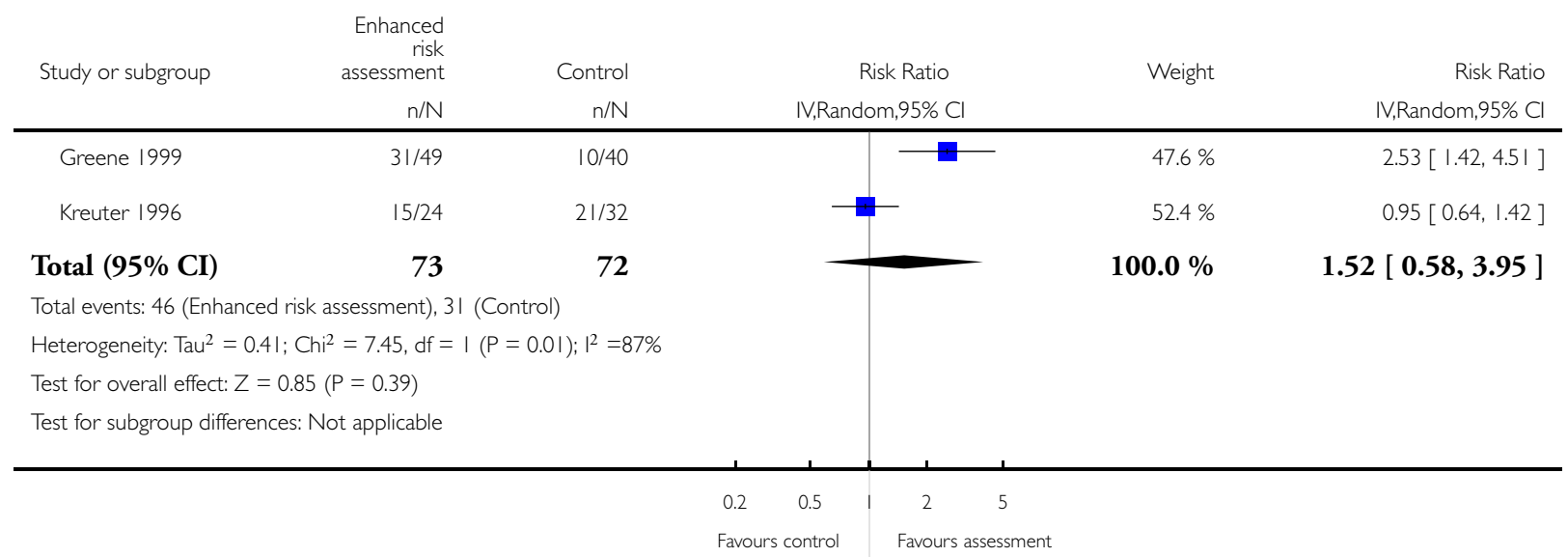

\section{Analysis 10.I. Comparison 10 Enhanced risk assessment vs other, Outcome I Uptake of screening.}

Review: Interventions targeted at women to encourage the uptake of cervical screening

Comparison: 10 Enhanced risk assessment vs other

Outcome: I Uptake of screening

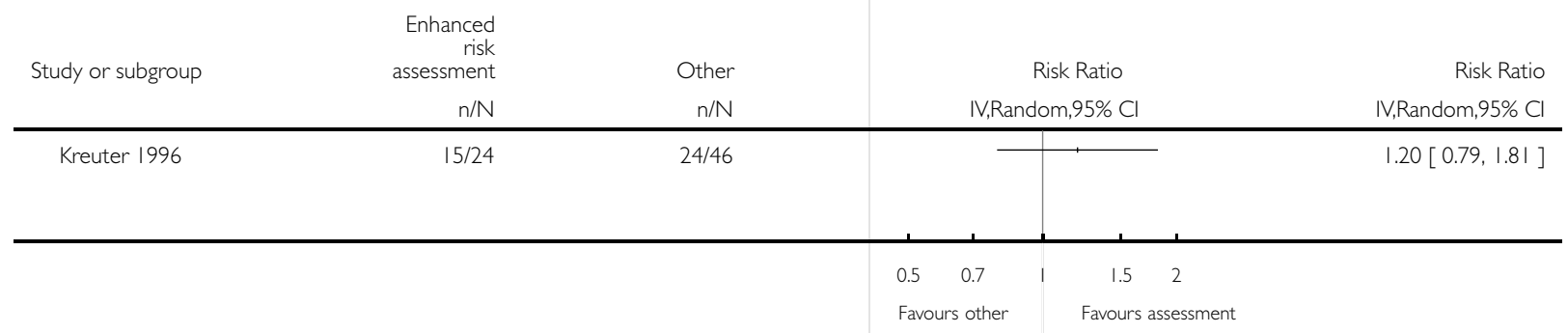




\section{Analysis I I.I. Comparison I I Access to health promotion nurse vs control, Outcome I Uptake of screening.}

Review: Interventions targeted at women to encourage the uptake of cervical screening

Comparison: II Access to health promotion nurse vs control

Outcome: I Uptake of screening

$\begin{array}{llll}\text { Study or subgroup } & \text { Nurse access } & \text { Control } & \text { Risk Ratio Risk Ratio }\end{array}$

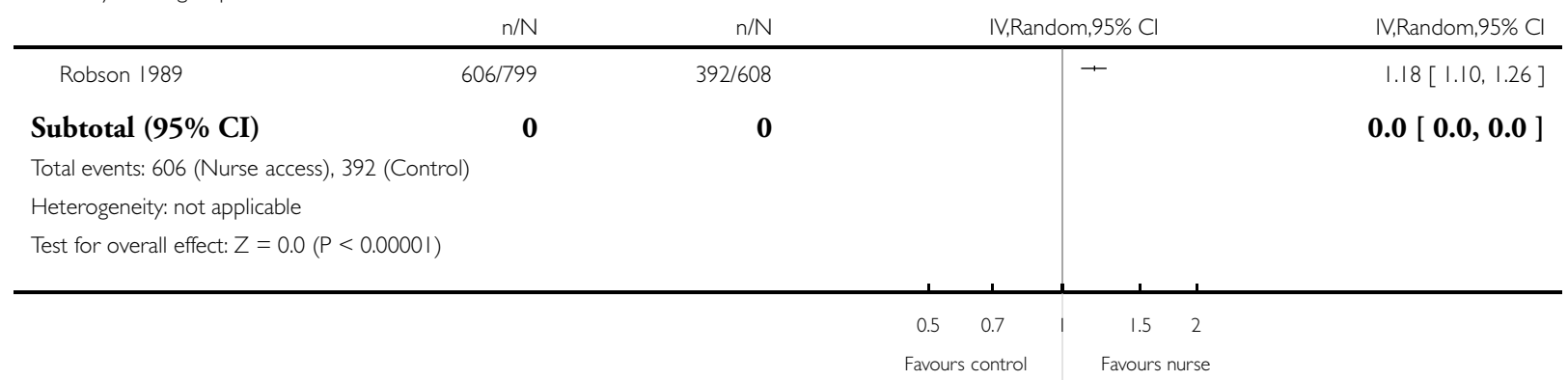

Analysis I2.I. Comparison I2 Photocomic vs placebo comic, Outcome I Uptake of screening.

Review: Interventions targeted at women to encourage the uptake of cervical screening

Comparison: 12 Photocomic vs placebo comic

Outcome: I Uptake of screening

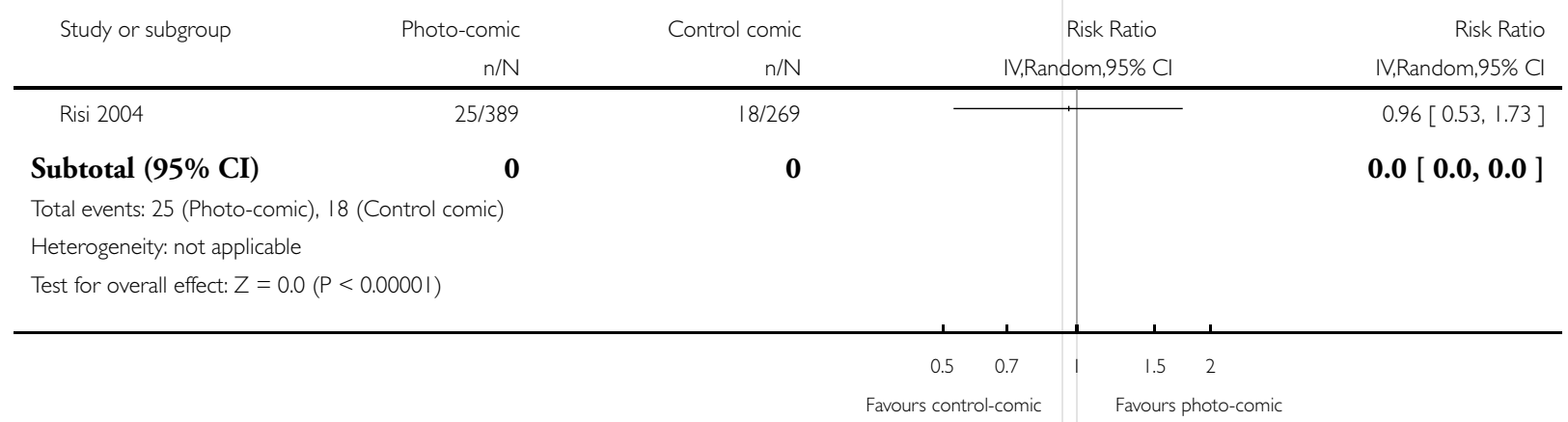




\section{Analysis 13.I. Comparison I 3 Intensive recruitment attempts vs control, Outcome I Uptake of screening.}

Review: Interventions targeted at women to encourage the uptake of cervical screening

Comparison: 13 Intensive recruitment attempts vs control

Outcome: I Uptake of screening

Study or subgroup $\quad$ Experimental $\quad$ Control Risk Ratio Ratio

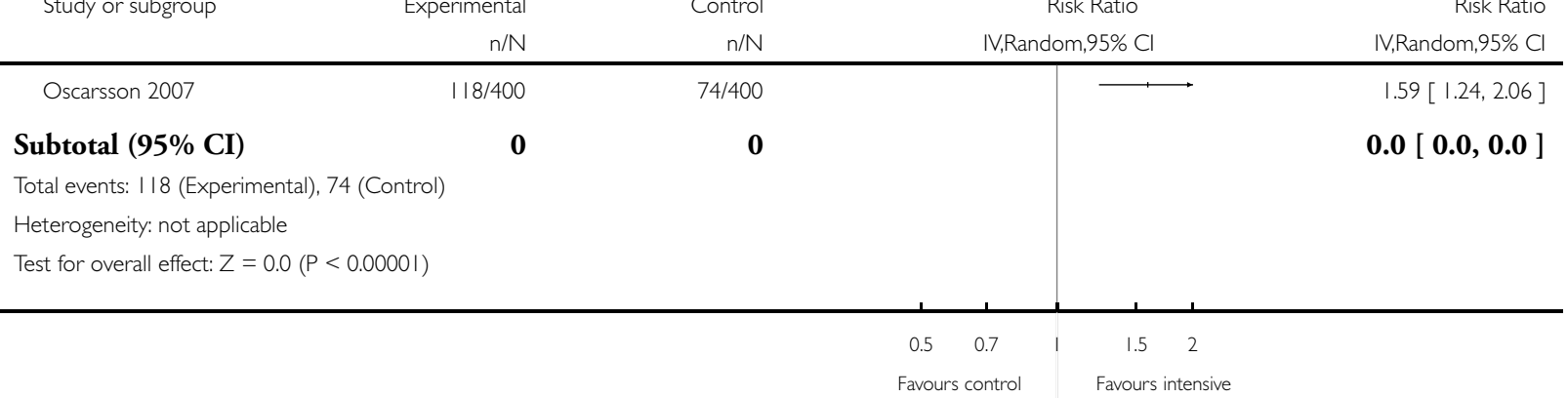

Analysis 14.I. Comparison I 4 Message framing, Outcome I Gain versus loss message framing (Detection).

Review: Interventions targeted at women to encourage the uptake of cervical screening

Comparison: 14 Message framing

Outcome: I Gain versus loss message framing (Detection)

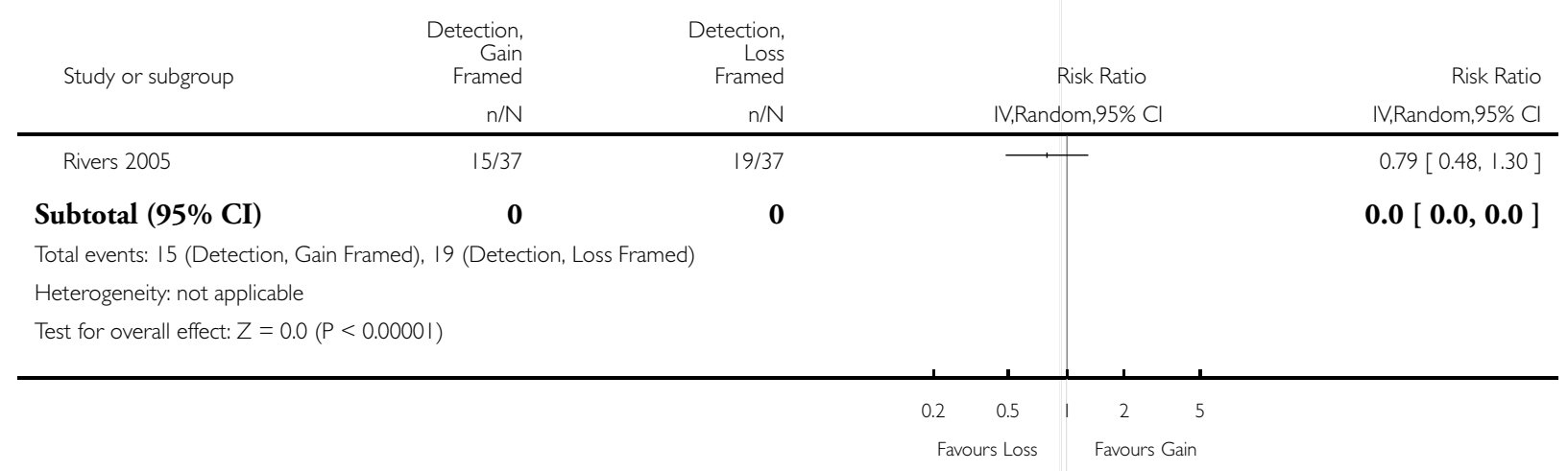




\section{Analysis 14.2. Comparison 14 Message framing, Outcome 2 Gain versus loss message framing (Prevention).}

Review: Interventions targeted at women to encourage the uptake of cervical screening

Comparison: 14 Message framing

Outcome: 2 Gain versus loss message framing (Prevention)

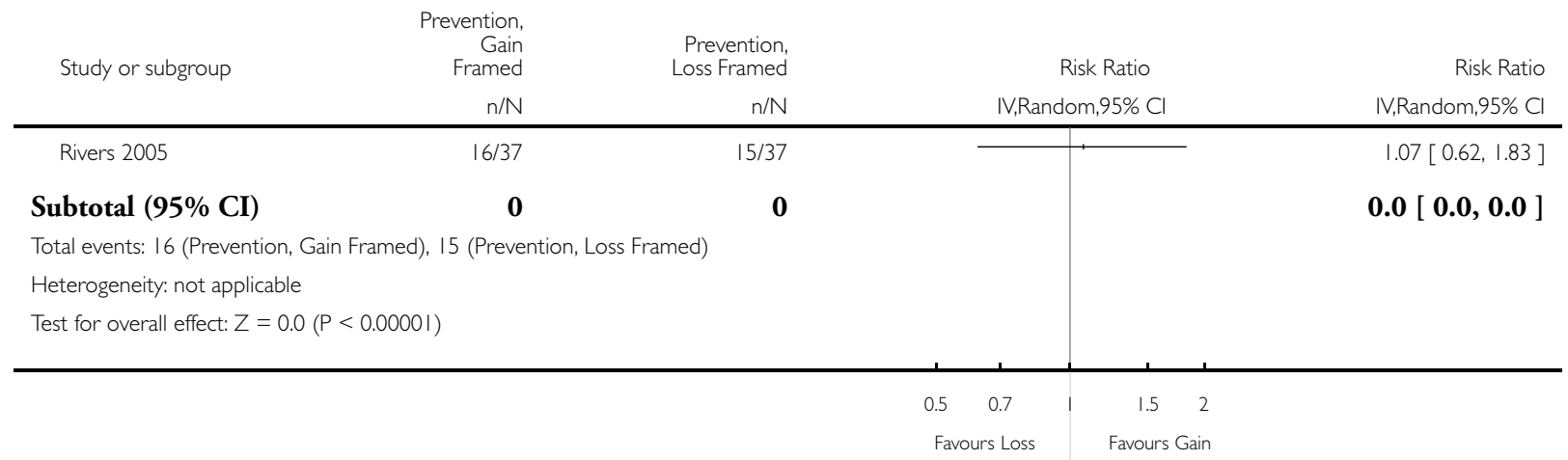

\section{Analysis 14.3. Comparison I4 Message framing, Outcome 3 Gain Message Framing: Prevention vs} Detection.

Review: Interventions targeted at women to encourage the uptake of cervical screening

Comparison: 14 Message framing

Outcome: 3 Gain Message Framing: Prevention vs Detection

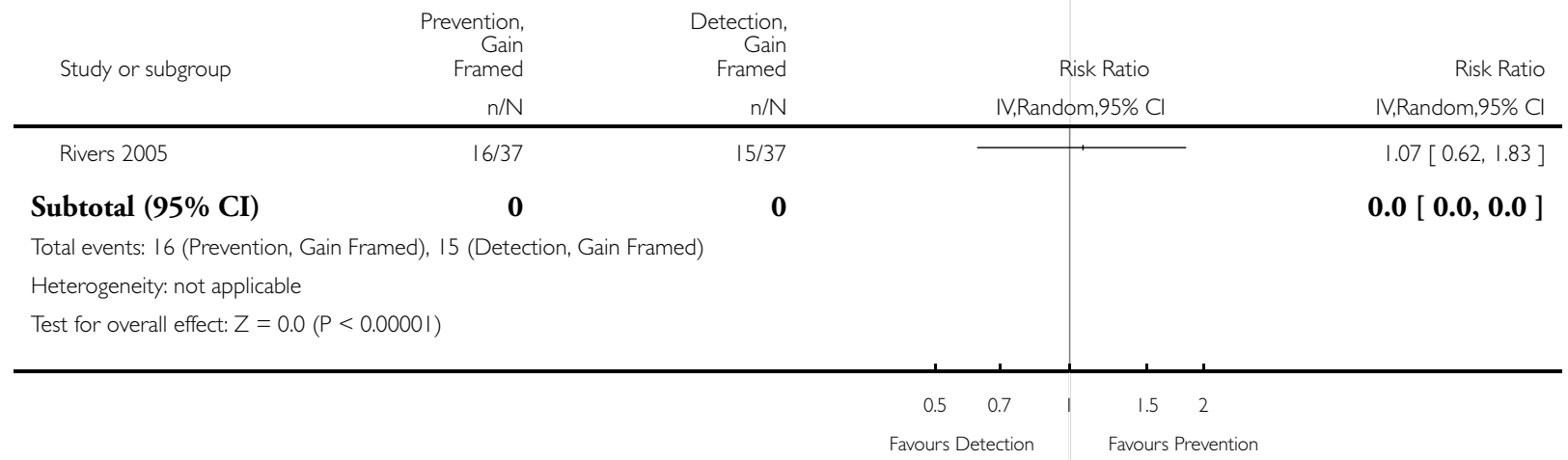




\section{Analysis 14.4. Comparison I4 Message framing, Outcome 4 Loss Message Framing: Prevention vs Detection.}

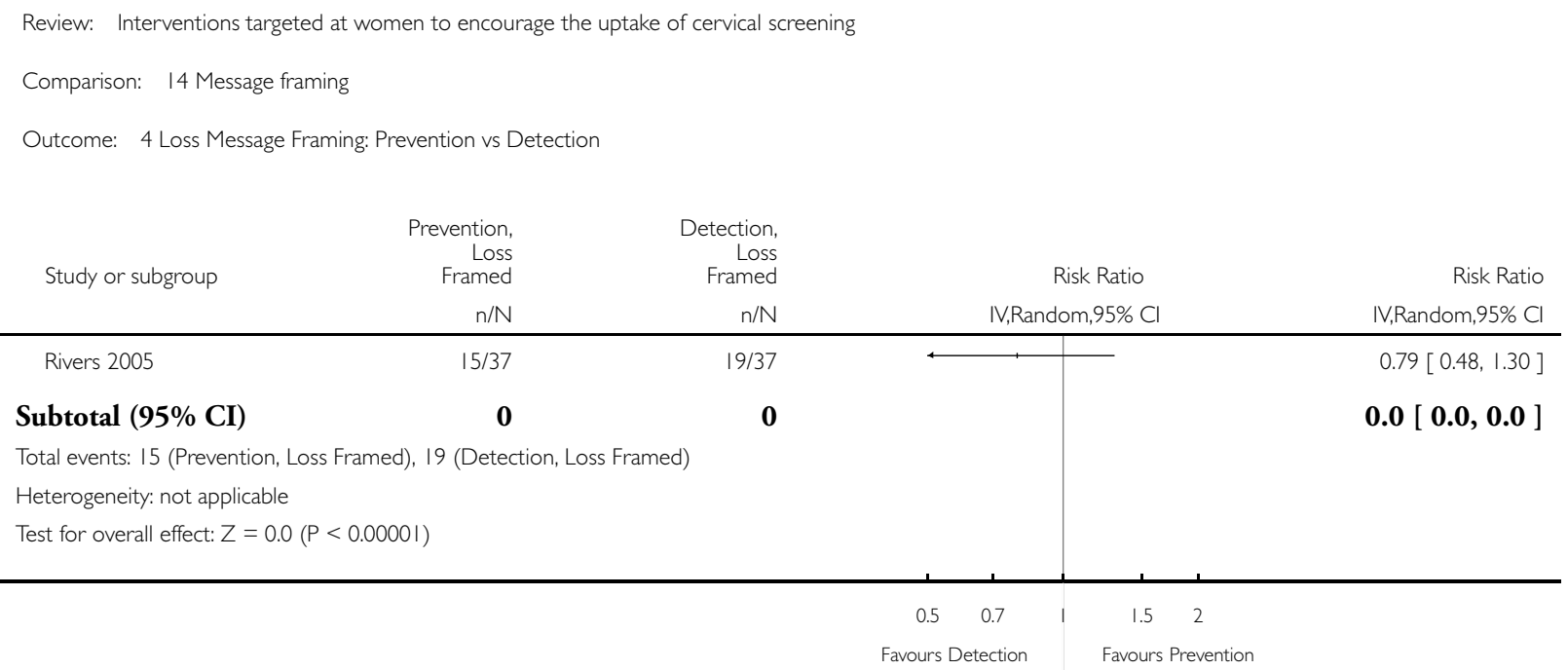

ADDITIONAL TABLES

Table 1. Details of secondary outcomes

\begin{tabular}{|c|c|c|c|}
\hline Study details & Interventions & Secondary outcome(s) & Results \\
\hline Binstock 1997 & $\begin{array}{l}\text { 1. Telephone call } \mathrm{n}=1526 \text { (1526 } \\
\text { analysed) } 2 \text {. Letter } \mathrm{n}=1526 \text { (1526 } \\
\text { analysed) } 3 \text {. Memo to woman's pri- } \\
\text { mary provider } \mathrm{n}=1526 \text { ( } 1,526 \text { anal- } \\
\text { ysed) 4. Chart reminder affixed to } \\
\text { outside of woman's medical record } \\
\mathrm{n}=1526 \text { ( } 1526 \text { analysed) } 5 \text {. Control } \\
\text { group } \mathrm{n}=1526 \text { (1526) }\end{array}$ & Costs & $\begin{array}{l}\text { Total estimated costs }(\$ U S) \text { per inter- } \\
\text { vention: } 1 . \$ 4,282 ; 2 . \$ 1,918 ; 3 . \$ 8 \text {, } \\
933 ; 4 . \$ 1,0.90 ; 5 \text {. Not stated. Esti- } \\
\text { mated cost (\$US) per additional Pap } \\
\text { smear performed: } 1 . \$ 7.99 ; 2 . \$ 4.76 ; 3 \text {. } \\
\$ 22.96 ; 4 . \$ 2.99 ; 5 . \text { Not applicable }\end{array}$ \\
\hline Byles 1995 & $\begin{array}{l}1 . \\
\text { Personally addressed letter with sim- } \\
\text { ple information about Pap smears } n= \\
\text { ? ( } 1128 \text { analysed) 2. Personally ad- } \\
\text { dressed letter combined with a series } \\
\text { of targeted behavioural prompts (e. } \\
\text { g. prompt cards) designed to address } \\
\text { aspects believed to be associated with } \\
\text { poor screening rates } n=?(1098 \text { anal- } \\
\text { ysed) } 3 \text {. Control } n=?(1414 \text { analysed) }\end{array}$ & Acceptability of the intervention & $\begin{array}{l}\text { Number (\%) of responding women re- } \\
\text { ceiving the intervention: } 1.154(72 \%) \\
\text {; } 2.134(78 \%) \text { letter, } 100(58 \%) \text { card, } \\
109(64 \%) \text { pamphlet; } 3 \text {. Not applica- } \\
\text { ble. Number (\%) of women responders } \\
\text { who said they had read the material } \\
\text { sent: } 1.147(69 \%) \text {; } 2.128(75 \%) \text { let- } \\
\text { ter, } 7(4 \%) \text { card, } 101(59 \%) \text { pamphlet; } \\
3 . \text { Not applicable. For intervention } 1 . \\
118 / 151(78 \%) \text { of the women said that } \\
\text { they were pleased to have the inter- } \\
\text { vention personally addressed to them, }\end{array}$ \\
\hline
\end{tabular}




\begin{tabular}{|c|c|c|c|}
\hline & & & $\begin{array}{l}\text { only } 1 / 151(1 \%) \text { said they were dis- } \\
\text { pleased and the remainder were not } \\
\text { sure. In intervention } 2.89 / 132(68 \%) \\
\text { were pleased, } 3 / 132(2 \%) \text { were dis- } \\
\text { pleased and the remainder were unsure. } \\
\text { In intervention } 1.152 / 155(98 \%) \text { of } \\
\text { the women thought that the interven- } \\
\text { tion should be sent to all women, } 2 / \\
155(1.3 \%) \text { did not and the remainder } \\
\text { were unsure. In intervention } 2.124 / \\
130(95 \%) \text { of women thought the in- } \\
\text { tervention should be sent to all women, } \\
1 / 130(1 \%) \text { did not and the remainder } \\
\text { were unsure }\end{array}$ \\
\hline McDowell 1989 & $\begin{array}{l}\text { 1. GP letter and reminder letter after } \\
21 \text { days } n=367 \text { ( } 367 \text { analysed) } \\
\text { 2. Physician reminder } n=332 \text { ( } 332 \\
\text { analysed) } \\
\text { 3. Telephone call } n=377 \text { ( } 377 \text { anal- } \\
\text { ysed) } \\
\text { 4. Control group } n=330 \text { ( } 330 \text { anal- } \\
\text { ysed) }\end{array}$ & Costs & $\begin{array}{l}\text { The costs for the GP letter were } \$ 14.23 \\
\text { per screening gained, compared with } \\
\$ 11.75 \text { assuming a salary of } \$ 60 \text { per } \\
\text { hour (or } \$ 5.88 \text { at } \$ 30 \text { per hour ) per } \\
\text { screening gained }\end{array}$ \\
\hline Greene 1999 & $\begin{array}{l}\text { 1. Usual care } \mathrm{n}=79 \text { (? analysed) re- } \\
\text { ceived general dietary and health in- } \\
\text { formation } \\
\text { 2. Cancer education } \mathrm{n}=97 \text { (? anal- } \\
\text { ysed) received general information } \\
\text { about cervical cancer risk factors and } \\
\text { screening recommendations } \\
\text { 3. Cognitive behavioral intervention } \\
\mathrm{n}=97 \text { (? analysed) received feed- } \\
\text { back about personal risk for cancer } \\
\text { and engaged in a clinical interview } \\
\text { to enhance self-efficacy for preventa- } \\
\text { tive behaviour }\end{array}$ & Booking of appointments & $\begin{array}{l}\text { Women in group } 1 \text {. were more likely } \\
\text { to schedule an appointment for a Pap } \\
\text { smear than those in group 3. (group } \\
1 .=79.4 \% \text { versus group } 3 .=36.7 \% \text {, } \\
\mathrm{P}</=0.0001 \text { ). Women in group } 1 \text {. } \\
\text { were also more likely to attend without } \\
\text { rescheduling the appointment (group } \\
1 .=63.9 \% \text { versus group } 3 .=35.4 \%, P<1 \\
=0.001 \text { ). Group } 2 \text {. did not differ from } \\
\text { group } 3 \text {. on these measures }\end{array}$ \\
\hline Vogt 2003 & $\begin{array}{l}\text { 1. Usual care control } \\
\text { 2. Letter/letter intervention: Sub- } \\
\text { jects were sent a letter and relevant } \\
\text { brochure. Women who had not at- } \\
\text { tended for screening within } 6 \text { weeks } \\
\text { were sent a further letter emphasis- } \\
\text { ing the importance of screening and } \\
\text { providing a number to call } \\
\text { 3. Letter/phone intervention: Let- } \\
\text { ter and brochure as above. Women } \\
\text { who had not attended for screening }\end{array}$ & Costs & $\begin{array}{l}\text { The letter/letter intervention produced } \\
\text { one additional Pap smear for } \$ 185 \text {. The } \\
\text { phone/phone intervention cost } \$ 305 \\
\text { and the letter/phone intervention cost } \\
\$ 1117 \text { for each additional Pap smear }\end{array}$ \\
\hline
\end{tabular}


Table 1. Details of secondary outcomes (Continued)

\begin{tabular}{|c|c|c|c|}
\hline & $\begin{array}{l}\text { within } 6 \text { weeks received a telephone } \\
\text { call by study interventionist who of- } \\
\text { fered to schedule appointments, an- } \\
\text { swer questions, address barriers and } \\
\text { concerns and discussing the impor- } \\
\text { tance of screening } \\
\text { 4. Phone/phone intervention: Sub- } \\
\text { jects in this group received two se- } \\
\text { quential telephone calls, the second } \\
\text { coming } 6 \text { weeks after the first if they } \\
\text { had not been screened in the in- } \\
\text { terim. Contents of the initial letter } \\
\text { and phone scripts were similar. Fol- } \\
\text { low-up telephone calls were by study } \\
\text { interventionist, as above }\end{array}$ & & \\
\hline Stein 2005 & $\begin{array}{l}\text { 1. Control. No Intervention. } \mathrm{n}=285 \\
\text { 2. Telephone call. Telephone call } \\
\text { from experienced research nurse us- } \\
\text { ing a prepared script. Maxiumum of } \\
\text { three attempts were made on consec- } \\
\text { utive days. } \mathrm{n}=285 \\
\text { 3. Letter from Health Authority } \\
\text { District Cervical Screening Commi- } \\
\text { sioner on behalf of National Cervi- } \\
\text { cal Screening Programme. } \mathrm{n}=285 \\
\text { 4. Letter from a well known journal- } \\
\text { ist and broadcaster (Claire Rayner) } \\
\text { who is also Chair of the Patients As- } \\
\text { sociation. } \mathrm{n}=285\end{array}$ & Costs & $\begin{array}{l}\text { Average cost per attender was } £ 145 \text {. } \\
12 \text { for telephone call, } £ 14.29 \text { for letter } \\
\text { from commissioner and } £ 37.14 \text { for let- } \\
\text { ter from celebrity }\end{array}$ \\
\hline Oscarsson 2007 & $\begin{array}{l}\text { 1. Control. No intervention. } \mathrm{n}=400 \\
\text { 2. Intervention included invitation } \\
\text { letters, telephone interviews and } \\
\text { promotive efforts for having a cervi- } \\
\text { cal smear taken. } \mathrm{n}=400\end{array}$ & Costs & $\begin{array}{l}\text { Cost of extra Pap smear gained was cal- } \\
\text { culated 151.36EURO. The cost of a } \\
\text { smear in the intervention group was } \\
\text { calculated at 66.87EURO each and } 16 . \\
\text { 63EURO in the control group }\end{array}$ \\
\hline
\end{tabular}




\section{A P P E N D I CES}

\section{Appendix I. Updated MEDLINE search strategy}

Medline Ovid 2000-March week 22009

1. Vaginal Smears/

2. (vagina* adj 5 smear*).mp.

3. (pap* ${ }^{*}$ adj5 (test* or smear*)).mp.

4. (cervi* adj5 (smear* or screen*)).mp.

5. ((cytology or cytobrush) and cervi*).mp.

6. 1 or 2 or 3 or 4 or 5

7. exp "Patient Acceptance of Health Care"/

8. (satisf* or dropout* or drop out).mp.

9. (compliance or complie* or comply*).mp.

10. (encourage* or improve* or improving or increas* or promot $\left.^{*}\right)$.mp.

11. (uptake or particip* or nonattend $\left.{ }^{*}\right)$.mp.

12. (accept* or attend* $^{*}$ or attitude* or utilisation or utilization).mp.

13. (refus* or respon* or reluctan* or nonrespon*).mp.

14. 7 or 8 or 9 or 10 or 11 or 12 or 13

15. 6 and 14

16. randomized controlled trial.pt.

17. controlled clinical trial.pt.

18. randomized.ab.

19. randomly.ab.

20. trial.ab.

21. groups.ab.

22. 16 or 17 or 18 or 19 or 20 or 21

23. 15 and 22

key: $\mathrm{mp}=$ title, original title, abstract, name of substance word, subject heading word, $\mathrm{pt}=$ publication type, fs=floating subheading

\section{Appendix 2. Updated Embase search strategy}

Embase Ovid 1980 to 2009 wk 13

1. exp Vagina Smear/

2. (vagina* ${ }^{*}$ dj 5 smear*).mp.

3. (pap* adj5 (test* or smear*)).mp.

4. (cervi* adj5 (smear* or screen $\left.\left.{ }^{*}\right)\right)$.mp.

5. ((cytology or cytobrush) and cervi*).mp.

6. 1 or 2 or 3 or 4 or 5

7. exp Patient Attitude/

8. (satisf* or dropout* or drop out).mp.

9. (compliance or complie* or comply*).mp.

10. (encourage* or improve* or improving or increas* or $^{*}$ promot $\left.^{*}\right)$.mp.

11. (uptake or particip* or nonattend*).mp.

12. (accept* or attend $^{*}$ or attitude* or utilisation or utilization).mp.

13. (refus* or respon* or reluctan* or nonrespon*).mp.

14. 7 or 8 or 9 or 10 or 11 or 12 or 13

15. 6 and 14

16. exp controlled clinical trial/

17. randomized.ab.

18. randomly.ab.

19. trial.ab.

20. groups.ab. 
21. 16 or 17 or 18 or 19 or 20

22. 15 and 21

key: $\mathrm{mp}=$ title, abstract, subject headings, heading word, drug trade name, original title, device manufacturer, drug manufacturer name, $\mathrm{ab}=\mathrm{abstract}$

\section{Appendix 3. Updated Central search strategy}

CENTRAL Issue 12009

1. MeSH descriptor Vaginal Smears explode all trees

2. vagina* near $/ 5$ smear*

3. pap* near $/ 5$ (test* or smear*)

4. cervi* near/5 (smear* or screen*)

5. (cytology or cytobrush) and cervi*

6. (\#1 OR \#2 OR \#3 OR \#4 OR \#5)

7. satisf* or dropout* or drop out

8. compliance or complie* or comply*

9. encourage* or improve* or improving or increas* or promot ${ }^{*}$

10. uptake or particip* or nonattend*

11. accept ${ }^{*}$ or attend* or attitude* or utilisation or utilization

12. refus* or respond* or reluctan* or nonrespond*

13. (\#7 OR \#8 OR \#9 OR \#10 OR \#11 OR \#12)

14. (\#6 AND \#13)

\section{Appendix 4. LILACS search strategy}

LILACS database (to 03/04/2009)

vagina \$ or cervi\$ [Palavras] and smear\$ or screen\$ [Palavras] and ( $R A N D O M I Z E D$ CONTROLLED TRIAL") [Tipo de publicação]

\section{WHAT'S NEW}

Last assessed as up-to-date: 28 March 2011.

\begin{tabular}{lll}
\hline Date & Event & Description \\
\hline 29 March 2011 & New citation required but conclusions have not changed & New authors added and text amendments. \\
\hline 29 March 2011 & New search has been performed & Changes to text and new authors added. \\
\hline
\end{tabular}




\section{H I S T O R Y}

Protocol first published: Issue 4, 2000

Review first published: Issue 3, 2002

\begin{tabular}{lll}
\hline Date & Event & Description \\
\hline 15 May 2002 & New citation required and conclusions have changed & Substantive amendment \\
\hline
\end{tabular}

\section{CONTRIBUTIONS OFAUTHORS}

In the original review, Carol Forbes and Ruth Jepson selected the studies, assessed study quality, extracted and analysed the data, and wrote the protocol and final review. Pierre Martin-Hirsch commented on the protocol and will be responsible for updating the review.

In the updated review Thomas Everett, Pierre Martin-Hirsch and Michelle Griffin drafted the clinical sections of the review and were responsible for sifting of studies and data extraction; Andrew Bryant drafted the methodological and statistical sections of the review and were responsible for carrying out the analyses. All authors agreed the final version.

\section{DECLARATIONSOF INTEREST}

No known conflict of interest.

\section{SOURCES OF SUPPORT}

\section{Internal sources}

- NHS Centre for Reviews \& Dissemination, UK.

\section{External sources}

- NHS R\&D Health Technology Assessment (HTA) Programme, UK.

- Department of Health, UK.

NHS Cochrane Collaboration programme Grant Scheme CPG-506

\section{DIFFERENCESBETWEEN PROTOCOLANDREVIEW}

Review is an update so differences between protocol and review is not applicable. The updated review uses a revised search strategy, more appropriate statistical analyses and incorporates up to date Cochrane methodology in accordance with the Cochrane handbook 2008. 


\section{N D EX TERMS}

\section{Medical Subject Headings (MeSH)}

*Patient Acceptance of Health Care; Mass Screening [*utilization]; Precancerous Conditions [diagnosis]; Randomized Controlled Trials as Topic; Reminder Systems; Uterine Cervical Neoplasms [ ${ }^{*}$ diagnosis; prevention \& control]; Vaginal Smears [ ${ }^{*}$ utilization]

\section{MeSH check words}

Female; Humans 